\title{
Reviews and syntheses: Effects of permafrost thaw on Arctic aquatic ecosystems
}

\author{
J. E. Vonk ${ }^{1}$, S. E. Tank ${ }^{2}$, W. B. Bowden ${ }^{3}$, I. Laurion ${ }^{4}$, W. F. Vincent ${ }^{5}$, P. Alekseychik ${ }^{6}$, M. Amyot ${ }^{7}$, M. F. Billet ${ }^{8}$, \\ J. Canário ${ }^{9}$, R. M. Cory ${ }^{10}$, B. N. Deshpande ${ }^{5}$, M. Helbig ${ }^{11}$, M. Jammet ${ }^{12}$, J. Karlsson ${ }^{13}$, J. Larouche ${ }^{3}$, G. MacMillan ${ }^{7}$, \\ M. Rautio ${ }^{14}$, K. M. Walter Anthony ${ }^{15}$, and K. P. Wickland ${ }^{16}$ \\ ${ }^{1}$ Department of Earth Sciences, Utrecht University, 3584 CS, Utrecht, the Netherlands \\ ${ }^{2}$ Department of Biological Sciences, University of Alberta, Edmonton, AB, T6G 2E9, Canada \\ ${ }^{3}$ Rubenstein School of Environment and Natural Resources, University of Vermont, Burlington, Vermont, 05405, USA \\ ${ }^{4}$ Centre d'études nordiques (CEN), Centre Eau Terre Environnement, Institut national de la recherche scientifique, QC, \\ G1K 9A9, Canada \\ ${ }^{5}$ Centre d'études nordiques (CEN), Takuvik Joint International Laboratory \& Département de biologie, Université Laval, \\ Québec City, QC, G1V 0A6, Canada \\ ${ }^{6}$ Department of Physics, University of Helsinki, P.O. Box 48, 00014, Helsinki, Finland \\ ${ }^{7}$ Centre d'études nordiques (CEN), Département de sciences biologiques, Université de Montréal, Montreal, QC, H2V 2S9, \\ Canada \\ ${ }^{8}$ Biological \& Environmental Sciences, School of Natural Sciences, University of Stirling, Stirling, FK9 4LA, UK \\ ${ }^{9}$ Centro de Química Estrutural, Instituto Superior Técnico, Universidade de Lisboa, Lisboa, Portugal \\ ${ }^{10}$ Department of Earth and Environmental Sciences, University of Michigan, Ann Arbor, Michigan, USA \\ ${ }^{11}$ Département de géographie, Université de Montréal, Montréal, QC, Canada \\ ${ }^{12}$ Center for Permafrost, Department of Geosciences and Natural Resource Management, University of Copenhagen, \\ Copenhagen, Denmark \\ ${ }^{13}$ Climate Impacts Research Centre (CIRC), Department of Ecology and Environmental Science, Umeå University, 98107, \\ Abisko, Sweden \\ ${ }^{14}$ Centre d'études nordiques (CEN), Department of fundamental sciences, Université du Québec à Chicoutimi, Chicoutimi \\ (Québec) G7H 2B1, Canada \\ ${ }^{15}$ Water and Environmental Research Center, University of Alaska Fairbanks, Fairbanks, Alaska 99775, USA \\ ${ }^{16}$ National Research Program, US Geological Survey, 3215 Marine St., Boulder, Colorado, USA
}

Correspondence to: J. E. Vonk(j.e.vonk@uu.nl)

Received: 15 June 2015 - Published in Biogeosciences Discuss.: 10 July 2015

Revised: 17 November 2015 - Accepted: 19 November 2015 - Published: 8 December 2015

\begin{abstract}
The Arctic is a water-rich region, with freshwater systems covering about $16 \%$ of the northern permafrost landscape. Permafrost thaw creates new freshwater ecosystems, while at the same time modifying the existing lakes, streams, and rivers that are impacted by thaw. Here, we describe the current state of knowledge regarding how permafrost thaw affects lentic (still) and lotic (moving) systems, exploring the effects of both thermokarst (thawing and collapse of ice-rich permafrost) and deepening of the active layer (the surface soil layer that thaws and refreezes each year). Within thermokarst, we further differentiate between
\end{abstract}

the effects of thermokarst in lowland areas vs. that on hillslopes. For almost all of the processes that we explore, the effects of thaw vary regionally, and between lake and stream systems. Much of this regional variation is caused by differences in ground ice content, topography, soil type, and permafrost coverage. Together, these modifying factors determine (i) the degree to which permafrost thaw manifests as thermokarst, (ii) whether thermokarst leads to slumping or the formation of thermokarst lakes, and (iii) the manner in which constituent delivery to freshwater systems is altered by thaw. Differences in thaw-enabled constituent delivery can 
be considerable, with these modifying factors determining, for example, the balance between delivery of particulate vs. dissolved constituents, and inorganic vs. organic materials. Changes in the composition of thaw-impacted waters, coupled with changes in lake morphology, can strongly affect the physical and optical properties of thermokarst lakes. The ecology of thaw-impacted lakes and streams is also likely to change; these systems have unique microbiological communities, and show differences in respiration, primary production, and food web structure that are largely driven by differences in sediment, dissolved organic matter, and nutrient delivery. The degree to which thaw enables the delivery of dissolved vs. particulate organic matter, coupled with the composition of that organic matter and the morphology and stratification characteristics of recipient systems will play an important role in determining the balance between the release of organic matter as greenhouse gases $\left(\mathrm{CO}_{2}\right.$ and $\left.\mathrm{CH}_{4}\right)$, its burial in sediments, and its loss downstream. The magnitude of thaw impacts on northern aquatic ecosystems is increasing, as is the prevalence of thaw-impacted lakes and streams. There is therefore an urgent need to quantify how permafrost thaw is affecting aquatic ecosystems across diverse Arctic landscapes, and the implications of this change for further climate warming.

\section{Introduction}

Permafrost is perennially frozen ground that underlies about a quarter of the landmass of the Northern Hemisphere (Brown et al., 1998). It consists of various soil types ranging from frozen peat and frozen mineral soil to frozen Pleistocene deposits rich in massive ground ice. The distribution of permafrost is generally divided into four zones based on the percentage of the land that is underlain by permafrost: continuous (90-100\%), discontinuous (50-90\%), sporadic $(10-50 \%)$, and isolated $(<10 \%)$ (Fig. 1). Terrestrial permafrost (we do not consider subsea permafrost in this review) hosts about $1330-1580 \mathrm{Pg}\left(1 \mathrm{Pg}=10^{15} \mathrm{~g}\right)$ organic carbon (OC) of which about half is deeper than $1 \mathrm{~m}$ (Schuur et al., 2015). Over the last few decades, permafrost ground temperatures have been slowly increasing (Romanovsky et al., 2010) as a result of increased surface warming in Arctic regions (IPCC, 2013).

The Arctic is extremely rich in water. Lakes, reservoirs, rivers, and various types of wetlands, floodplains, bogs, fens, and mires, on average occupy $16 \%$ of the landscape underlain by permafrost when considering water bodies larger than $0.1 \mathrm{~km}^{2}$ in area (Fig. 1; Global Lakes and Wetlands Database; Lehner and Döll, 2004) making this number a conservative estimate. Discontinuous, sporadic, and isolated permafrost regions are relatively rich in surface water with 20,23 , and $18 \%$ landscape coverage, respectively, compared to continuous permafrost with only $11 \%$. Water, in all its forms, con- nects all components of the landscape and plays a key role in the storage and transport pathways of sediments, organic matter, nutrients, and other constituents (Battin et al., 2009; Vonk and Gustafsson, 2013). The role of hydrology is therefore key in both the response and the effects of permafrost thaw, and it strongly influences the balance of carbon dioxide $\left(\mathrm{CO}_{2}\right)$ and methane $\left(\mathrm{CH}_{4}\right)$ emissions. At the same time, permafrost thaw will also create new aquatic ecosystems and modify existing aquatic ecosystems. In this review we provide an overview of the effects of permafrost thaw on aquatic ecosystems and their potential effects on climate, with a consideration of all aquatic ecosystems located within the permafrost zones defined by Brown et al. (1998; Fig. 1).

When permafrost thaws, the soil organic matter and minerals within it become available for remobilization and introduction into aquatic systems. The type of thaw will largely determine the rate and effects of this remobilization. Here, we will distinguish between two types of thaw: (i) thaw of ice-rich permafrost, also called thermokarst, with a more abrupt or episodic character that tends to manifest as a pulse disturbance, and (ii) thaw of permafrost with (relatively) low ground-ice content, with a gradual but persistent and longerterm character that tends to manifest as a press disturbance (Grosse et al., 2011). In this review we consider the effects of both pulse and press thaw disturbances.

Thaw of ice-rich permafrost leads to a range of landscape features (Fig. 2) that are collectively referred to as thermokarst, and that are typically divided into three primary groups based on where and how they form (Kokelj and Jorgenson, 2013): (i) hillslope processes, (ii) wetland processes, and (iii) thermokarst lake processes. Hillslope processes result in dramatic features such as retrogressive thaw slumps (Fig. 2b), active layer detachment slides, and thermal erosional gullies (Fig. 2c), which together we refer to as thermoerosional features (TEFs). The scale of these features is local and depends on landscape features, but the transport of sediment, nutrients, and organic matter into aquatic ecosystems can be large, and these features may form in a matter of hours and slowly grow for several years. Wetland processes include peatland collapse and the development of bogs and fens. While wetlands store significant quantities of soil carbon (Tarnocai et al., 2009) they are not specifically discussed in this review. Thermokarst lake processes, which include lake and pond formation, expansion, and drainage, are the most abundant (10-50\% of permafrost-impacted landscapes; Jorgenson et al., 2006; Kokelj and Jorgenson, 2013) and most easily recognizable form of thermokarst, and are particularly emphasized in this review.

Thaw of permafrost with lower ice content results in a more gradual top-down thawing process, and occurs through active layer deepening and talik formation (Schuur et al., 2008). This type of thaw is gradual but can occur over entire landscapes (Åkerman and Johansson, 2008; Shiklomanov et al., 2013). Although its impact on aquatic ecosystems is harder to detect and requires long-term (decades-scale) mon- 


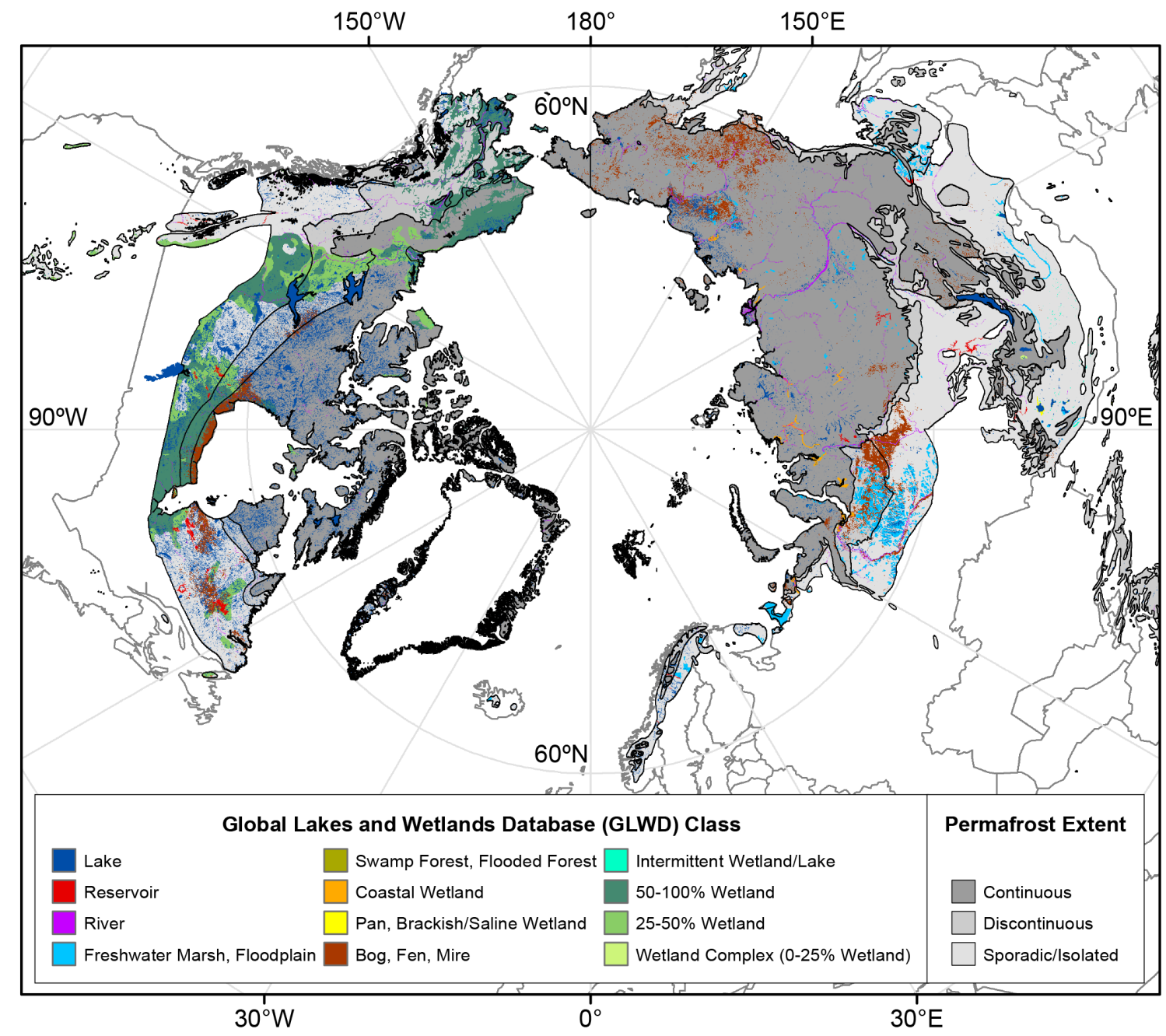

Figure 1. Map of the permafrost zones in the Northern Hemisphere (greyscale; Brown et al., 1998) superimposed on water bodies from the Global Lakes and Wetlands Database (Lehner and Döll, 2004).

itoring, such gradual thaw can cause striking changes to regional hydrology and chemistry (e.g. in Alaska, Striegl et al., 2005; Keller et al., 2010; Walvoord et al., 2012). Talik formation occurs under water bodies, but also when the active layer has deepened to such an extent that the soil does not refreeze completely in winter. Taliks create new hydrological hotspots in the landscape, and may increase groundwater flow and deepen flow paths, particularly in the case of open taliks that fully penetrate the permafrost profile (Walvoord et al., 2012) and alter fluxes of constituents (Walvoord and Striegl, 2007).

While ground ice content and topography are important modifying factors that determine how permafrost thaw manifests itself within landscapes, factors such as the local composition of soils and regional extent of permafrost will also play an important role in determining the effect of permafrost thaw on aquatic ecosystems (Fig. 3). For example, continued permafrost degradation, and in particular the transition from continuous to discontinuous permafrost, will considerably lengthen flow paths, often enable greater inputs of groundwater to freshwater systems, and affect the processing of water en route to aquatic systems (e.g. Striegl et al., 2005; Walvoord et al., 2012). Thermokarst processes along with other climate-driven changes in, for example, vegetation and precipitation, also determine local hydrological trajectories that affect the landscape in contrasting ways (e.g. lake expansion vs. drainage) (Bouchard et al., 2013; Turner et al., 2014). Similarly, local soil conditions (e.g. composition, porosity) will affect how permafrost thaw changes soil-water interactions as water moves across landscapes, with the mobilization or exposure of organic vs. mineral soils being an important potential regulator of how thaw affects impacted aquatic systems (Tank et al., 2012a).

In this review, we first describe the general impacts of permafrost thaw on aquatic ecosystems such as changes in physical, optical, and chemical limnology and the release of 

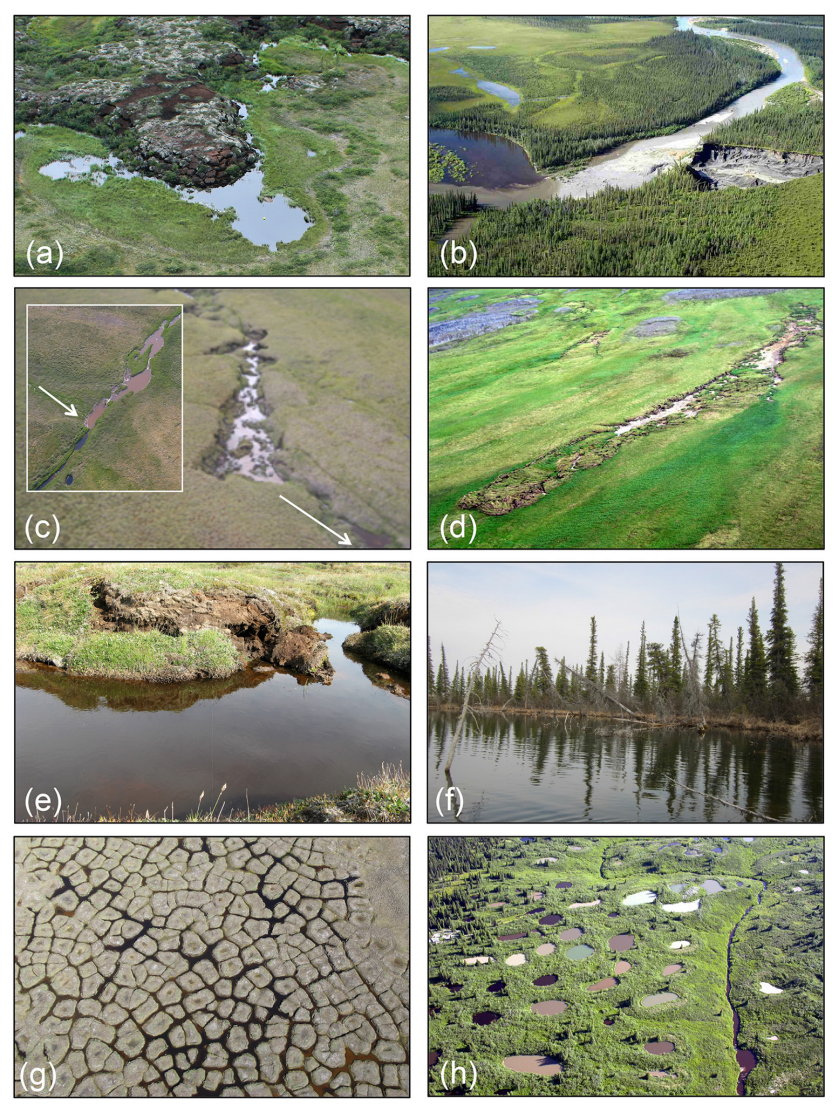

Figure 2. Photos of typical thermokarst processes: (a) Thermokarst lake SAS1, located in a sub-Arctic peat bog near KuujjuarapikWhapmagoostui, Québec, Canada. The water body lies next to a thawing, organic-rich palsa (permafrost mound), and is $25 \mathrm{~m}$ in its maximum dimension. (b) Massive thaw slump on the Selawik River near Selawik, Alaska, US. Sediment discharge from the feature has entirely blocked the river. Note the turbidity downstream. (c) Gully thermokarst on the Toolik River, Alaska, US, and impact on receiving stream (inset), (d) active layer detachment slides near the Anaktuvuk River burn area on the North Slope of Alaska, (e) trough pond on Bylot Island, Nunavut, Canada featuring active erosion, (f) thermokarst lakes in Mackenzie Delta, Northwest Territories, Canada, showing active shoreline slumping, (g) polygonal landscape on Bylot Island, showing ice-wedge trough ponds, and (h) thermokarst lakes and ponds with a wide range in colour near Kuujjuarapik-Whapmagoostui, Québec, Canada. Photo credits: (a), Bethany Deshpande; (b), Benjamin Crosby, (c, d), William Breck Bowden; (e, g, h), Isabelle Laurion; (f), Suzanne Tank.

materials from land to water (Sect. 2). We identify the various pathways of organic carbon and contaminant degradation (bio- and photodegradation), and the resulting changes in microbial community structure and gas fluxes from thawimpacted systems (Sect. 3). We then evaluate the broader consequences of permafrost thaw for aquatic ecosystems considering the release of old carbon into waters and the atmosphere, carbon burial, effects on ecosystem structure and functioning, and exports to the ocean (Sect. 4). We end this review with a summary of our findings and recommendations for future research (Sect. 5).

\section{Impacts of thaw on aquatic ecosystems}

\subsection{Physical and optical limnology}

The land area above latitude $45.5^{\circ} \mathrm{N}$ totals 41.3 million $\mathrm{km}^{2}$ and contains around 200000 lakes (sized 0.1 to $50 \mathrm{~km}^{2}$ ), with $73 \%$ of them occurring in permafrost landscapes (Smith et al., 2007; Grosse et al., 2011, 2013). Thermokarst lakes and ponds, defined as water bodies that form in a depression as a result of permafrost thaw, are among the most abundant water bodies in permafrost landscapes, and can be found throughout the circumpolar north, from North America to Europe and Russia. They encompass a wide range of physical characteristics, which in turn contribute to the large variations in their biogeochemical properties. In this section, we focus on the effects of thermokarst on the physical and optical limnology of ponds and lakes (Fig. 4). We acknowledge, however, that thermokarst processes will also have significant effects on the physical properties of stream and river systems, for example via the delivery of coloured or chromophoric dissolved organic matter (CDOM) and sediments to these environments (see Sect. 2.2).

Thermokarst lakes occur in cold, high-latitude environments that experience prolonged winters with sub-zero temperatures for 8 months or more of the year, and short summers with air temperatures that may rise well above $10^{\circ} \mathrm{C}$ depending on location. They tend to have minimal hydrological connectivity given their frozen surroundings, which inhibit the infiltration and exchange of water. As a result, the hydrological balance of these closed basins is strongly influenced by snowmelt in spring, evaporation and precipitation in summer, and water inflow from local permafrost soils as a result of thermokarst processes (Fig. 4; Dingman et al., 1980; Bowling et al., 2003; Smith et al., 2007). Notable exceptions are the thermokarst lakes located in floodplain deltas, where river waters may flood and connect the lakes each year, depending on their height above the main stem of the river (McKnight et al., 2008). Thermokarst lake disappearance is a common process throughout the Arctic (e.g. in Siberia, Smith et al., 2005; Kravtsova and Bystrova, 2009).

Thermokarst lakes vary greatly in surface area, from ponds that are only a few metres across (northern Québec, Breton et al., 2009; Bouchard et al., 2011) to lakes that are several kilometres in their maximum dimension (Alaska, Pelletier, 2005 and Arp et al., 2011; western Siberia, Pokrovsky et al., 2011). In some thermokarst-impacted landscapes, ponds and lakes can cover up to $30 \%$ of land surface area (estimated with remote sensing in NW Canada, Côté and Burn, 2002; and in Alaska, Hinkel et al., 2005), although subpixelscale water bodies could substantially increase the total water surface area as was demonstrated in the Lena Delta of 


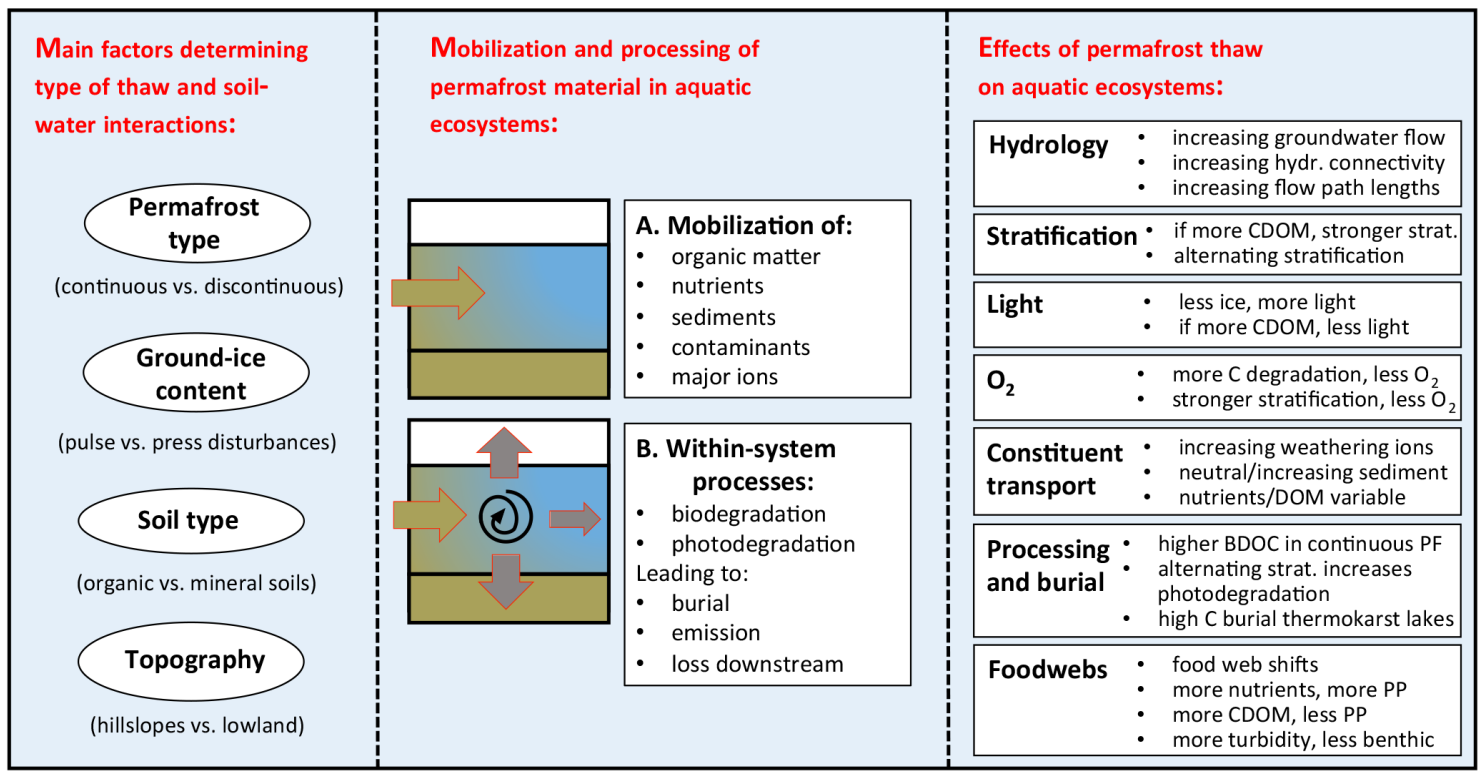

Figure 3. Conceptual diagram of (left) factors determining thaw type and soil-water interactions, (middle) mobilization and processing of permafrost material into aquatic ecosystems, and (right) effects of permafrost thaw on aquatic ecosystems.

Siberia (Muster et al., 2013). Their depth is limited by local geomorphology and thaw depth of the permafrost, resulting in shallow waters in some areas, and much deeper systems in other regions. Depth is an important feature in determining lake characteristics as it determines whether water bodies are frozen to the bottom in winter. Typically, thermokarst lakes are rather shallow. For example, in northern Québec, in a region extending from continuous to discontinuous and sporadic permafrost, maximum lake depths range from 1 to $3.5 \mathrm{~m}$ (Breton et al., 2009; Laurion et al., 2010; Bouchard et al., 2011; Crevecoeur et al., 2015). Similarly, lake depths range from 0.5 to $1.5 \mathrm{~m}$ on a discontinuous permafrost tundra in western Siberia (Pokrovsky et al., 2013), from 0.4 to $2.6 \mathrm{~m}$ in an area of continuous permafrost in northern Alaska (Arp et al., 2011), and from 1 to $3.5 \mathrm{~m}$ in continuous permafrost of the Arctic Coastal Plain (Hinkel et al., 2012). However, thermokarst lakes approaching $10 \mathrm{~m}$ depth can be found in interior Alaska (Sepulveda-Jauregui et al., 2015) and lakes deeper than $10 \mathrm{~m}$ can be found on the Seward Peninsula, Alaska (Hopkins, 1949) and northeast Siberia (Walter Anthony and Anthony, 2013); thermokarst lakes as deep as $22 \mathrm{~m}$ exist on the Yukon Coastal Plain of north-western Canada (West and Plug, 2008). The size and abundance of thermokarst lakes are changing, but with pronounced differences between regions. In Russia, thermokarst lake area has been increasing in mid-latitudes but decreasing in southern Siberia (Kirpotin et al., 2008; Sharonov et al., 2012). However, High Arctic thermokarst lakes have also been expanding (e.g. on the Yamal Peninsula, Sannikov et al., 2012). Lake area changes may vary substantially (i.e. both increasing and decreasing) even within smaller regions, for ex- ample in Altai (Polishuk and and Sharonov, 2013) or northwest Siberia (Bryksina et al., 2011). In summary, thermokarst lakes and ponds occur in wide varieties (Fig. 2) depending on, for example, their formation process, surface area, and depth; from here on we generally distinguish between ponds and lakes based on their depth (ponds freeze to the bottom in winter, lakes do not), but also sometimes use "lakes" loosely for both systems when the distinction is less clear, or we follow the terminology used in the studies we cite.

Ongoing thermokarst can result in variable inputs of dissolved organic carbon (DOC), inorganic solutes (including nutrients and major ions), and particulate organic and mineral materials into these lakes. Consequently, their limnological properties are highly influenced by their regional surroundings (Fig. 4; Prowse et al., 2006; Bowden et al., 2008; Watanabe et al., 2011; see Sect. 2.2 below). One of the expressions of that variability is the colour of the water, which although typically brown, may sometimes be blue, green, black or even white. A study by Watanabe et al. (2011) on water colour and light attenuation in the thaw waters of Nunavik, Québec (Fig. 2h), showed that the lake surface colour (water-leaving spectral radiance) was dependent upon the combined concentrations of CDOM and suspended nonalgal particulate material, allowing certain biogeochemical properties such as DOC to be estimated from satellite remote sensing. Waters rich in CDOM (or in clays and silts) strongly attenuate solar radiation, and suppress primary production (see Sect. 4.3.1). In shallower and clearer waters, sufficient photosynthetically active radiation may penetrate to the bottom of the lakes to allow the development of aquatic macrophytes; for example in lakes of the Mackenzie River 

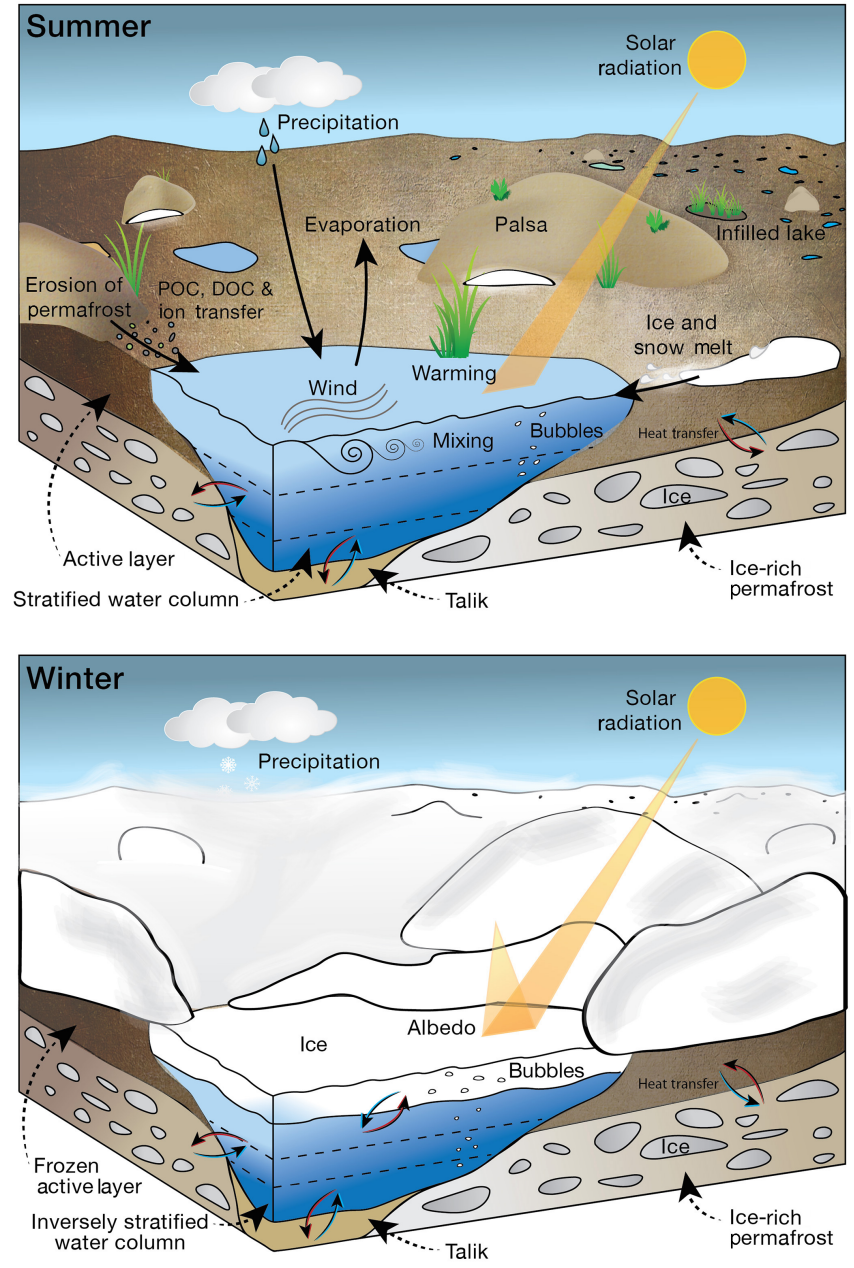

Figure 4. Physical limnological characteristics of permafrost thaw lakes in the ice-free and ice-covered seasons. Note that shallow ponds and lakes that freeze to the bottom in winter are not considered in this schematic.

delta that are less affected by flooding with turbid river water (Squires and Lesack, 2003).

Depending on their CDOM and particle content, the surface waters of thermokarst lakes may strongly absorb solar radiation, and this can give rise to pronounced surface warming of the more coloured lakes. In combination with the cooling of their bottom waters by the permafrost beneath, this means that some thermokarst lakes have pronounced vertical thermal and density gradients in summer (Fig. 4, Alaska, Sepulveda-Jauregui et al., 2015). In winter, ice-cover reduces transfer of energy with the atmosphere and eliminates potential wind mixing, although some transfer of heat may result from the oxidation of organic matter in bacterial sediment processes if lakes are not frozen to the bottom (Mortimer and Mackereth, 1958).

Many thermokarst lakes are likely to be cold polymictic, undergoing stratification events that become established and then break down over diurnal, or several day, cycles (Alaska, Hinkel et al., 2012; Canadian sub-Arctic, Deshpande et al., 2015). The increased use of high resolution, automated temperature loggers is likely to yield new insights into these short term stratification and mixing dynamics, even in those lakes currently considered to be well-mixed in summer. For example, in western Siberia, an air-temperature increase of $15^{\circ} \mathrm{C}$ from an anomalous heat wave resulted in increased surface-water temperatures of $10^{\circ} \mathrm{C}$, and the formation of a strong temperature gradient in the water column (Pokrovsky et al., 2013). Strong thermal stratification during summer has been reported in shallow ( $<3 \mathrm{~m}$ maximum depth) thermokarst lakes and ponds in sub-Arctic Québec (Laurion et al., 2010; Deshpande et al., 2015), the high Canadian Arctic (Bouchard et al., 2015), northern Siberia (Boike et al., 2015), and in lakes on yedoma-like permafrost in a latitudinal transect in Alaska (Sepulveda-Jauregui et al., 2015). In these shallow, stratified systems, oxygen depletion is more prevalent, especially in bottom waters (Deshpande et al., 2015; Sepulveda-Jauregui et al., 2015). On the other hand, lakes in non-yedoma permafrost or non-permafrost catchments in Alaska tended to be less stratified, with welloxygenated bottom waters. In thermokarst lakes located at higher latitudes, particularly in tundra zones with reduced vegetation, little or no stratification has been observed during summer (Yukon Territory, Canada, Burn, 2003; Alaska, Hinkel et al., 2012; western Siberia, Pokrovsky et al., 2013), possibly as a result of greater wind exposure (a function of fetch and wind speed), the reduced tendency of cold waters to stratify (the change in water density per unit ${ }^{\circ} \mathrm{C}$ is lower at lower temperatures), increased convective mixing, and less near-surface light absorption and heating. Deep thermokarst lakes ( $>2 \mathrm{~m}$; not freezing to the bottom in winter) show strong inverse stratification beneath their ice-cover during winter (e.g. Canadian (sub-)Arctic, Breton et al., 2009; Laurion et al., 2010; Deshpande et al., 2015; Alaska, SepulvedaJauregui et al., 2015; Siberia, Boike et al., 2015), including those lakes that show little or no stratification in summer (e.g. Yukon Territory, Canada, Burn, 2003). Shallow water bodies (depth $<2 \mathrm{~m}$ ) may freeze all the way to the bottom in winter; for example on the Arctic Coastal Plain of Alaska, where the ice thickness reaches 1.5-2 m depths (Arp et al., 2011).

Stratification within lakes is also influenced by gradients in salinity and gas concentrations that contribute to density differences down the water column (Kirillin et al., 2012). Such effects are also likely in thermokarst lakes, but have received little attention to date. Thermokarst processes result in inputs of eroded permafrost material into these water bodies, including POC (particulate organic carbon) and DOC, nutrients, and ions (Mackenzie Delta uplands, Kokelj et al., 2005; circum-Arctic, Prowse et al., 2006; Alaska, Bowden et al., 2008), which are further concentrated with the lake freeze-up during winter (Canadian Arctic, Grasby et al., 2013; Canadian sub-Arctic, Deshpande et al., 2015), in turn affecting water column stability. The hydrodynamic effects 
of high dissolved $\mathrm{CH}_{4}$ and $\mathrm{CO}_{2}$ gradients under ice in stratified thermokarst lakes and of the gas bubble trains associated with ebullition from sediments (Siberia, Walter et al., 2006) have received little attention.

The combination of high rates of bacterial metabolism, small lake volumes, and prolonged ice cover means that thermokarst lakes (that do not freeze to the bottom in winter) can experience full water column anoxia for much of the year, in striking contrast to the well-known deeper, non-thermokarst lakes in the Arctic such as Toolik Lake, Alaska, and Char Lake, Canada (Deshpande et al., 2015). In thermokarst lakes in sub-Arctic Québec, mixing in spring occurs during an extremely short period of time $(<5 \mathrm{~d})$ before the lakes re-stratify (Laurion et al., 2010). Mixing at that time may be insufficient to completely re-oxygenate the water column, while in autumn, prolonged mixing, likely aided by convective processes, results in the transfer of oxygen to the bottom of the lake (Deshpande et al., 2015). In a study near Mayo, Yukon Territory (Canada) by Burn (2003), a similar pattern was observed, of prolonged, substantial mixing in autumn but only a short period of mixing in spring, which may favour the continuation of bottom water anoxia throughout summer. The autumn mixing period is likely to be especially important for gas exchange with the atmosphere, and for stimulating aerobic processes such as bacterial respiration and methanotrophy throughout the water column.

Presently, there are major gaps in our understanding of the physical and hydrological dynamics of thermokarst lakes, including measurements of heat transfer from the sediments, the penetration of solar radiation through winter ice cover, the potential for internal seiches in winter influenced by floating ice, and the nature of groundwater flows (Kirillin et al., 2012). Advective transfer of liquid water from shallower littoral zones to the pelagic bottom waters due to differential cooling may also play a role in material transfer within these water bodies, as has been observed elsewhere (MacIntyre and Melack, 1995); no studies to date have addressed the three dimensional hydrodynamics of thaw waters.

\subsection{Chemical limnology and the transfer of materials from land to water}

Permafrost thaw and thermokarst processes can have a major effect on the chemistry of impacted aquatic ecosystems. Particularly in thermokarst lakes, these changes may occur as a result of the optical and physical processes described above Where thermokarst affects lake stratification, for example, changes in phosphorus remobilization from sediments could occur (e.g. Sondergaard et al., 2003). However these effects have been little studied in thaw-impacted systems. Similarly, changes in water column and sediment oxygenation will change the prevalence of redox reactions, including the bacterially mediated processes described in Sects. 3.4 and 3.5, below. In addition to these classic "limnological" changes, permafrost thaw can also be expected to have a fundamen- tal effect on the transfer of sediments and chemical constituents from land to water. A recent review by Frey and McClelland (2009) provides an in-depth discussion of how this change may play out for nutrients, DOC, and major ions in stream and river systems. In this section, we update this previous work and add a consideration of the specific effects of thermokarst and permafrost thaw via active layer deepening on lake water chemistry.

\subsubsection{Press vs. pulse disturbances}

The degree to which nutrients, organic matter, and sediments are released into aquatic systems is likely to depend on the type of permafrost thaw. For example, the press disturbance of active layer deepening (time scale of decades, and greater) will likely favour the delivery of soluble materials (nutrients, base cations, DOC), although the mechanisms that deliver soluble materials to aquatic systems are complex, as outlined below (see Sect. 2.2.3). In contrast, the pulse disturbance of thermo-erosional processes (localized time scale of years to decades) is likely to favour the delivery of particulate over soluble materials. In addition, hydrologic connectivity and landscape topography are also likely to affect land-to-water constituent transfer (Abnizova et al., 2014), and further affect carbon burial or transfer to the atmosphere. For example, high-gradient watersheds may experience much more lateral constituent transfer, while in low-gradient watersheds with low specific runoff the vertical emission of carbon as $\mathrm{CO}_{2}$ and $\mathrm{CH}_{4}$ may predominate.

The spatial distribution and life cycle of press and pulse disturbances will also govern the impact that they have on the delivery of biogeochemical constituents to aquatic ecosystems. For example, TEFs (thermo-erosional features) are discretely distributed across the landscape, following variations in topography (affecting, for example, snow cover; Godin et al., 2015) and ground ice content. While these features can be numerous in impacted areas (Lacelle et al., 2015) they take up a relatively small percentage of the total landscape area (1.5\% in Alaska; Krieger, 2012). Individual TEFs have lifecycles on the order of decades (Kokelj et al., 2013; Pearce et al., 2014), and - while they are active - may have intense local impacts on sediment and ionic fluxes to freshwater systems (see below). They also seem likely to act as a population of features, however, only a small portion of which will be active at any one time within the landscape. As a result, the observed significant local effects may become more muted when averaged over wider landscapes. In contrast, the press disturbance of active-layer thickening occurs more universally across the landscape, but results in changes that are much more subtle, and may require long-term (decadesscale) monitoring programs to detect. Slow press changes can operate over many decades, altering aquatic ecosystems (e.g. in Alaska, Keller et al., 2010; Walvoord et al., 2012), and causing entire landscapes to slowly subside (Alaska, Shiklomanov et al., 2013). 


\subsubsection{Sediment delivery to aquatic ecosystems}

Thermo-erosional features either directly adjacent to, or within the catchment of, aquatic systems can significantly increase suspended sediment concentrations, particularly in streams and rivers where turbulence causes materials to remain entrained. Thaw slumps and gullies directly adjacent to streams have been shown to cause order-of-magnitude increases in suspended sediment concentrations (Alaska, Bowden et al., 2008; Calhoun, 2012) that can continue to be seen for considerable distance downstream (western Canadian Arctic, Kokelj et al., 2013). For example, one small thermokarst gulley that formed in 2003 and intersected a small, headwater beaded-stream (the Toolik River) in a $0.9 \mathrm{~km}^{2}$ Alaskan catchment delivered more sediment downslope to the river than is normally delivered in 18 years from a $132 \mathrm{~km}^{2}$ adjacent reference catchment of the upper $\mathrm{Ku}$ paruk River (Bowden et al., 2008). Similarly, streams impacted by within-catchment active layer detachments have been shown to exhibit elevated sediment levels at their outflow when compared to non-impacted sites (Canadian High Arctic, Lamoureux and Lafrenière, 2014). Where slumping occurs directly adjacent to lakes, however, slump-associated sediments can settle out of suspension rapidly, depending on particle size. Thus, while lakes impacted by permafrost slumping experience altered sedimentation rates (Mackenzie Delta uplands, Deison et al., 2012), water column sediment loads are generally not impacted (Mackenzie Delta uplands, Kokelj et al., 2005; Canadian High Arctic, Dugan et al., 2012). Similarly, increases in sediment loads are atypical in systems where thermokarst causes landscape collapse without significant exposure of soils, such as in the creation of thermokarst lakes in lowland regions. However, where postglacial silts and clays are present (which have very low sedimentation rates), for example on the eastern coast of Hudson Bay, permafrost thaw can have profound consequences on sediment loads to lakes (Bouchard et al., 2011; Watanabe et al., 2011).

\subsubsection{Organic matter delivery to aquatic ecosystems}

Increases in sediment delivery to aquatic ecosystems will in turn increase the flux of particulate organic carbon (POC) to affected systems. In the active-layer detachment system described above, increases in suspended sediments were accompanied by measured increases in POC (Canadian High Arctic, Lamoureux and Lafrenière, 2014). In lakes, permafrost thaw can change the rate of accumulation of organic matter in sediments, and depending on the composition of eroding materials, either increase (sub-Arctic Sweden, Vonk et al., 2012a) or decrease (Mackenzie Delta uplands, Deison et al., 2012) the concentration of sediment organic matter. Notably, the POC that travels to aquatic systems as a result of permafrost thaw may be only partially derived from permafrost carbon, because the action of thaw and landscape collapse will also expose and mobilize soils from the seasonally unfrozen active layer (e.g. Kokelj and Jorgenson, 2013). In Sect. 4.1.2, we review the effect of permafrost thaw on the mobilization of old organic carbon.

Where permafrost thaw enhances contact between water and organic soil horizons, increases in DOC concentrations are likely to occur. Direct slumping of old yedoma carbon into streams causes striking increases in DOC in adjacent receiving waters in the Kolyma River watershed (Vonk et al., 2013), while slumping adjacent to streams in the Alaskan Arctic is also associated with significantly increased stream water DOC at the site of impact (Abbott et al., 2014). During thaw of ice-rich permafrost, DOC stored in ice wedges and other ground ice (Fritz et al., 2015) is also released. Thermokarst lakes that form in organic-rich terrains can have significantly elevated concentrations of DOC as a result of direct contact between overlying water and recently submerged soils, and continued thermokarst expansion into new soils at the lake margin (e.g. sub-Arctic Québec, Breton et al., 2009; western Siberia, Shirokova et al., 2013). In regions where slumping increases delivery of inorganic particles from land to water, however, aquatic DOC concentrations can decrease as a result of the adsorption of organics onto sediment surfaces that settle after suspension (e.g. Mackenzie Delta uplands, Kokelj et al., 2005; sub-Arctic Québec, Bouchard et al., 2012).

In addition, thaw-enabled changes in flow paths can also be expected to affect the transport of DOC to aquatic ecosystems. Although there is little direct evidence for the effect of water interactions with deeper soil layers as active layers deepen in organic-rich regions, there are parallels to be drawn with more transitional (sub-Arctic) systems, where permafrost peatland plateaus are associated with low annual export (2-3 $\left.\mathrm{g} \mathrm{C} \mathrm{m}^{-2} \mathrm{yr}^{-1}\right)$ dominated by the snow melt period $(\sim 70 \%)$, and non-permafrost fens are characterized by much higher DOC export $\left(7 \mathrm{~g} \mathrm{C} \mathrm{m}^{-2} \mathrm{yr}^{-1}\right)$ due to more sustained annual hydrological connectivity (sub-Arctic Sweden, Olefeldt and Roulet, 2014). Conversely, where soils are characterized by shallow organic layers, growing season export of flow-weighted DOC has been shown to decrease significantly between the periods of 1978-1980 and 2001-2003 (Yukon River, Alaska, Striegl et al., 2005), likely as a result of the combined effect of increased flow paths (deeper active layer), residence time (Alaska, Koch et al., 2013), and microbial mineralization of DOC in the unfrozen soil and groundwater zone. Permafrost thaw as a result of wildfire has been shown to increase hydrologic connectivity between burned hillslopes and catchment surface waters, such that burned soils can become a dominant source of water and solutes to streams during summer, whereas unburned hillslopes provide longer term storage of water and solutes (Alaska; Koch et al., 2014). Recent forest fires in central Siberia (Parham et al., 2013) however, led to a decrease in stream DOC concentrations due to removal of a DOC source through combustion. In these regions, it has been suggested that organic 
matter sorption onto newly thawed (due to forest fires) mineral soils may also be important (Petrone et al., 2007). Over geographic gradients, changes in permafrost extent appear to have regionally variable effects on DOC flux from land to water, with decreasing permafrost extent (and presumably increasing contact with deeper soils and groundwater inflows) causing increasing DOC fluxes in organic rich regions, but decreasing DOC fluxes in regions with poorly developed organic horizons (Frey and Smith, 2005; Prokushkin et al., 2011; Tank et al., 2012a). Controlled leaching experiments of soils from the Alaskan and western Canadian Arctic have also found that regardless of temperature and leaching time, only small amounts of DOC are released from permafrostimpacted soils, and that mobilization of OC occurred largely in the POC phase (Guo et al., 2007).

\subsubsection{Nutrient delivery to aquatic ecosystems}

Similar to DOC, the effect of permafrost thaw on nutrient concentrations may also be region, or landscape specific. For thermo-erosional processes, direct slumping into Alaskan streams has been shown to increase dissolved inorganic and organic nutrient concentrations (Bowden et al., 2008; Abbott et al., 2014), while in the western Canadian Arctic, total dissolved $\mathrm{N}$ and $\mathrm{P}$ can be lower in shallow lakes directly impacted by permafrost slumping. This latter effect has been hypothesized to occur as a result of the adsorption of organic nitrogen and phosphorus onto settling mineral particles, or following rapid uptake and senescence, and then burial, of photosynthesizing cells (Mackenzie Delta uplands, Thompson et al., 2012). In lakes that remain turbid following thermokarst disturbances, total phosphorus concentrations can be high, following phosphorus adsorption onto clays that are transported into aquatic systems (sub-Arctic Québec, Breton et al., 2009). Similarly, slumping can also increase sediment nutrient concentrations (Mackenzie Delta uplands, Mesquita et al., 2010), while shoreline expansion of thermokarst lakes in yedoma regions can enable nutrientrich yedoma soils, and the nutrient-rich plants that these soils support, to enter lakes (Siberia, Walter Anthony et al., 2014).

Warming, coupled with landscape changes that decrease water contact with organic soils and increase water contact with inorganic soils has been shown in several Arctic regions to lead to higher nitrate concentrations in adjacent streams, as a result of decreased $\mathrm{NO}_{3}$ uptake or increased nitrification (e.g. Alaska, Jones et al., 2005 and Harms and Jones Jr., 2012; Canadian High Arctic, Louiseize et al., 2014). On the Alaskan North Slope, nitrate export from the upper Kuparuk River increased over a period of several decades, via mechanisms that may be linked to warming and permafrost thaw (McClelland et al., 2007). Conversely, deeper flow paths that increase contact with mineral soils are expected to decrease dissolved organic nitrogen exports (Alaska, Walvoord and Striegl, 2007; Harms and Jones Jr., 2012; Koch et al., 2013). Deepening flow paths may also lead to increased phosphorus concentrations, because mineral weathering is the primary source of phosphorus in soil waters (e.g. Frey and McClelland, 2009).

\subsubsection{Delivery of major ions}

Permafrost thaw is also expected to increase the concentration of weathering-derived ions in receiving waters, as slumping or deepening flow paths increases the contact between water and deeper mineral soil layers (see review in Frey and McClelland, 2009). For example, in the Alaskan Arctic, increasing thaw depths have been associated with increasing surface water concentrations of calcium and bicarbonate (Keller et al., 2010), while near-surface permafrost has been found to be ion-rich in the western Canadian Arctic. In Siberia, and at multiple locations throughout the panArctic, decreasing permafrost extent has also been associated with increasing stream water concentrations of major weathering ions (Frey et al., 2007; Tank et al., 2012a). This effect can be pronounced when thermokarst slumping occurs directly adjacent to aquatic systems: both streams (NW Canada, Malone et al., 2013) and lakes (Mackenzie Delta uplands, Kokelj et al., 2005) can exhibit strikingly elevated ionic concentrations when directly impacted by permafrost slumping.

\subsubsection{Mobilization of contaminants}

Contaminants reach polar regions following long-range atmospheric transport and deposition, as well as through increased local waste production from marine transport and industrial or mining activities. The frozen soils of permafrost have historically been considered a barrier to the movement of contaminants and many waste and dump sites use containment strategies that rely on the low mobility of contaminants in permafrost soils (Grannas et al., 2013). However, the warming Arctic climate may lead to an increased mobility of contaminants, either stored in soils at waste sites or historically accumulated in permafrost, into Arctic surface waters (Armitage and Wania, 2013; Chételat et al., 2014).

Thawing permafrost may have major consequences for contaminant transport and transformations in the Arctic due to the following: (a) physical changes in the hydrological cycle leading to the remobilization of contaminants from contaminated soils or sediments, (b) chemical changes due to the release of nutrients and organic carbon from previously frozen soils, and (c) biological changes via the microbial transformation of contaminants. Most studies on the interactions between contaminants and permafrost soils have concentrated on fuel products, persistent organic pollutants (POPs), and metals such as mercury $(\mathrm{Hg})$ and lead $(\mathrm{Pb})$.

Permafrost thaw may cause increased mobility of contaminants from catchment soils to surface waters due to accelerated soil/peat erosion, altered hydrological flow (increasing hydrological connectivity), and increased runoff leading to 
exposure of soluble contaminants (sub-Arctic Sweden, Klaminder et al., 2008). Increased lateral hydraulic conductivity may accelerate the downhill movement of contaminants through the large pores, lenses, and veins created in the active layer by the thawing of ice-rich permafrost (Mackenzie Delta region, Dyke, 2001). After thaw, permafrost is no longer an impermeable barrier to contaminants, allowing for infiltration into soils and aquatic systems (Grannas et al., 2013). The reduced surface area of thermokarst lakes in some areas due to the creation of drainage channels may lead to increased contaminant concentrations in the remaining surface waters (Macdonald et al., 2005).

Traditionally, the distinction is made between (i) organic contaminants, and (ii) inorganic contaminants. Studies of organic contaminants (hydrocarbons or non-aqueous phase liquids) predict lateral movement in the active layer with limited vertical transport in areas of continuous permafrost (Mackenzie Delta region, Dyke, 2001; Alaska, Carlson and Barnes, 2011). Vertical migration is possible in some regions (Alaska, McCarthy et al., 2004) yet permafrost acts as a low-permeability barrier in others (Antarctica, Curtosi et al., 2007). Organic contaminants may migrate downwards into frozen soils in areas of discontinuous permafrost due to more variable distribution (Alaska, Carlson and Barnes, 2011).

Studies of inorganic contaminants show that physical changes in permafrost affect contaminant mobility. For instance, Manasypov et al. (2014) observed geographical gradients in trace metal concentrations in surface waters from Siberia related to thermokarst lake evolution (from small permafrost depressions to larger lakes), mainly due to peat leaching. They also described seasonal differences in trace metal levels related to cycles of ice formation and melting (Manasypov et al., 2015). Further, studies using massbalance calculations and paleoecological techniques have linked thermokarst erosion in peatlands and the release of $\mathrm{Hg}$ into lake surface waters (sub-Arctic Sweden, Klaminder et al., 2008; Rydberg et al., 2010). Stable isotope analysis also suggests that the weak recovery of $\mathrm{Pb}$ contamination in two sub-Arctic lakes (despite dramatically reduced atmosphere inputs) may be linked to the subsidence of thawing permafrost soils (sub-Arctic Sweden, Klaminder et al., 2010). Permafrost degradation may affect the mobility of inorganic contaminants differently across different Arctic regions. Deison et al. (2012) found that Mackenzie Delta upland lakes impacted by the development of retrogressive thaw slumps in siliciclastic soils had lower levels of $\mathrm{Hg}$ in surface sediments when compared to reference lakes. In this instance, thaw slumping may have led to a dilution of organic material and associated mercury $(\mathrm{Hg})$ due to high inorganic sedimentation rates. On the other hand, MacMillan et al. (2015) showed that small thermokarst lakes located in sub-Arctic and High Arctic Canada dominated by slumping of organic soils showed elevated concentrations of $\mathrm{Hg}$ and toxic methylmercury. This was strongly related to inputs of organic matter and nutrients into surface waters.
In summary, permafrost has historically been considered an impermeable barrier to the movement of contaminants due to their low infiltration and mobility in frozen soils (Grannas et al., 2013). However, ongoing and future climate warming will likely disrupt the sequestration of contaminants in permafrost soils, which leads to enhanced leaching and mobility of organic and inorganic contaminants to nearby aquatic systems. This, however, will not necessarily result in increased contaminant concentrations due to a dilution effect by other materials transported along with the contaminant.

\subsubsection{Overarching considerations}

Overall, the manner in which permafrost thaw affects surface water chemistry as a result of changing land-to-water fluxes will be dependent on the constituent and the landscape. While evidence suggests that constituents such as suspended sediments and weathering ions will experience neutral to increasing effects in response to permafrost thaw, the effect on constituents such as DOC and nutrients is likely to be more variable. As a result, we must consider local conditions, including soil composition (mineral vs. organic-rich), the nature of thaw (e.g. thermokarst processes on hillslopes vs. within lowlands, vs. active layer deepening), and the current extent of permafrost (continuous vs. discontinuous) to best understand the effects of thaw on land-water fluxes of chemical constituents.

Particularly for streams, hydrological connectivity between sites of thaw and the stream system is also an important consideration, because lateral inputs are typically more influenced by conditions in the riparian and deeper subsurface zones than by conditions at ridge tops and the near surface (Stieglitz et al., 2003; Rastetter et al., 2004). Thus, in areas where permafrost is thawing rapidly, the proximity of thaw features to aquatic systems, and the hydrological conditions of local stream and subsurface zones are likely to have a strong influence on the biogeochemical imprint of lateral inputs to streams. While TEFs have the capacity to move large quantities of soils and nutrients downslope, hydrological connectivity must be present to enable these constituents to reach the stream for biogeochemical impact to occur.

\section{Pathways of degradation}

The carbon, nutrients, and contaminants that are delivered to aquatic ecosystems as a result of permafrost thaw will have a critical effect on the functioning of these systems. Changes in biological function (see Sect. 4) will determine the relative balance between processing within freshwater systems vs. loss via potential outflow pathways and the eventual delivery of these constituents to sediments (see Sect. 4.2) or "downstream" to the Arctic Ocean (see Sect. 4.4). In the case of carbon, differences in quality will affect whether processing and uptake results in the release of greenhouse gases (GHG), or C 
incorporation into microbially based food webs. At the same time, changes in stratification, redox, solubility, and oxygen availability (Sects. 2.1, 2.2, and 3.5.1) will affect the balance between $\mathrm{CO}_{2}$ and $\mathrm{CH}_{4}$ release. In this section, we review the dominant pathways of carbon and contaminant degradation in permafrost-thaw-impacted systems. We focus specifically on bio- and photodegradation pathways, and the effect of permafrost thaw on GHG emissions from thaw-impacted systems. The manner in which permafrost thaw affects nutrient uptake within aquatic systems is addressed in Sect. 4.3.

\subsection{Biodegradation of organic carbon}

In the Arctic, where transfers of organic $\mathrm{C}$ from soils to aquatic ecosystems can be especially strong (Kling et al., 1991), C fluxes from surface waters to the atmosphere, and from land to ocean, may represent up to $40 \%$ of the net landatmosphere $\mathrm{C}$ exchange (maximum flux of $\sim 0.16 \mathrm{Pg} \mathrm{C} \mathrm{yr}^{-1}$ compared to a net terrestrial sink of $0.4 \pm 0.4 \mathrm{PgC} \mathrm{yr}^{-1}$; McGuire et al., 2009). In many cases, these $\mathrm{C}$ fluxes from freshwaters to the atmosphere or to the coastal oceans are supported by the degradation of terrestrially derived DOC (e.g. Yukon River, Alaska, Spencer et al., 2008), although DIC (dissolved inorganic carbon) derived from weathering can also be an important $\mathrm{CO}_{2}$ source (Yukon River, Alaska, Striegl et al., 2012). Biological processing of DOC occurs prior to, and upon, hydrologic delivery to surface waters (Alaska, Michaelson et al., 1998; NE Siberia, Spencer et al., 2015). The biodegradability of DOC in various Arctic systems is dependent on several factors including DOC source and chemical character (Michaelson et al., 1998; Wickland et al., 2007, 2012; Balcarczyk et al., 2009; Mann et al., 2012; Olefeldt et al., 2013; Abbott et al., 2014), nutrient availability (Holmes et al., 2008; Mann et al., 2012; Wickland et al., 2012; Abbott et al., 2014), water temperature (Wickland et al., 2012), and prior processing (Michaelson et al., 1998; Wickland et al., 2007; Spencer et al., 2015). There are strong seasonal patterns in DOC biodegradability in large Arctic rivers, where the relative amount of biodegradable DOC (BDOC) is greatest in winter and spring, and generally declines through the summer and autumn (Holmes et al., 2008; Mann et al., 2012; Wickland et al., 2012; Vonk et al., 2015), reflecting the influences of seasonal thaw depth on DOC sources and hydrologic connectivity. Soil BDOC does not show a strong seasonality (Wickland et al., 2007; Vonk et al., 2015), supporting the notion that changes in DOC residence time and processing in soils prior to delivery to surface waters is a primary control on aquatic BDOC (Striegl et al., 2005; Vonk et al., 2015).

Permafrost presence and extent has direct and indirect influences on biodegradable DOC in aquatic ecosystems through its controls on potential sources and on hydrologic pathways and rate of delivery. A synthesis study by Vonk et al. (2015) of BDOC in circum-Arctic soils and surface waters finds higher BDOC in soils and aquatic systems with increasing permafrost extent. In the absence of direct slumping, sources of DOC in permafrost-impacted areas are restricted to surface litter and modern active layer soils, which have relatively high total and labile $\mathrm{C}$ contents that are readily accessible (e.g. Holmes et al., 2008), and thus are strong potential sources of BDOC. Deeper soils having generally lower $\mathrm{C}$ content are more accessible in discontinuous permafrost areas, and hydrologic flow paths with longer residence times allow for greater opportunity of DOC processing during transport (Alaska, Walvoord and Striegl, 2007) generally resulting in lower potential BDOC delivery to aquatic systems (Vonk et al., 2015). However, there are observations of increasing delivery of biodegradable DOC to aquatic ecosystems in areas of decreasing permafrost extent (western Siberia, Kawahigashi et al., 2004; Alaska, Balcarczyk et al., 2009), with one explanation being the preferential sorption of more recalcitrant hydrophobic DOC constituents to increasingly exposed/accessible mineral soils (Kawahigashi et al., 2004). Therefore broad generalizations of permafrost control on BDOC are still difficult to make with certainty.

Permafrost thaw and thermokarst formation can potentially impact biodegradable DOC in aquatic ecosystems by altering sources, rates, and pathways of hydrologic delivery. Newly thawed soils are potential DOC sources that can exceed DOC released from seasonally thawed active layer soils (sub-Arctic Sweden, Roehm et al., 2009; Alaska, Waldrop et al., 2010). Studies of distinct DOC sources suggest that non-permafrost-derived soil pore water DOC is moderately biodegradable (Wickland et al., 2007; Roehm et al., 2009; Vonk et al., 2015), whereas certain permafrost soilderived DOC can be highly biodegradable, particularly Pleistocene yedoma DOC in NE Siberia and Alaska (Vonk et al., 2013; Abbott et al., 2014; Spencer et al., 2015). These studies point to a high susceptibility of permafrost DOC to degradation during transport from soils, and within surface waters, compared to non-permafrost DOC, with aliphatic DOC originating in permafrost being preferentially degraded (NE Siberia, Spencer et al., 2015). Surface waters contain a mixture of DOC from different sources, and therefore it is difficult to isolate the relative biodegradability of permafrost soil vs. non-permafrost soil (active layer) derived DOC within surface waters (Holmes et al., 2008; Balcarczyk et al., 2009; Mann et al., 2012; Wickland et al., 2012). Frey et al. (2015) have shown a relatively constant proportion of bioavailable DOC ( $\sim 4.4 \%$; based on 5-day biological oxygen demand assays) along the flow-path continuum throughout the Kolyma River basin in Siberia. Actively thawing permafrost features, however, release elevated amounts of BDOC to low order water tracks and outflows (up to $40 \%$ BDOC after 30-40 days incubation; NE Siberia, Vonk et al., 2013; Alaska, Abbott et al., 2014), but significant biodegradation during transport to higher order streams and rivers remove substantial amounts of permafrost DOC before reaching major Arctic rivers and the ocean (NE Siberia, Mann et al., 2015; Spencer et al., 2015). Increasing hydrologic flow 
path lengths and residence time in soils in some areas as a result of permafrost thaw likely promote DOC processing and sorption within watersheds prior to discharge to surface waters (Yukon River, Alaska, Striegl et al., 2005), further reducing the likelihood of biodegradable permafrost DOC reaching aquatic systems.

Thermokarst can also release significant quantities of POC to aquatic ecosystems (Sect. 2.2), often substantially outweighing the amount of released DOC (assessed via direct measurements, or assuming a 1-2\% conversion between suspended sediments and POC; Bowden et al., 2008; Lewis et al., 2012; Vonk et al., 2013; Abbott et al., 2015). In streams impacted by thermokarst, POC will remain entrained for long distances downstream (NW Canada, Kokelj et al., 2013), and may reasonably be subject to significant biological decomposition as a result of this entrainment, as has been shown for other, temperate, systems (Richardson et al., 2013). Degradation of the POC delivered to aquatic systems as a result of permafrost thaw, however, has received little attention to date.

\subsection{Photodegradation of organic carbon}

Recent studies indicate that sunlight can play an important role in dissolved organic matter (DOM) degradation in thermokarst-impacted lakes and ponds (Alaska, Cory et al., 2013, 2014; Canadian High Arctic, Laurion and Mladenov, 2013; sub-Arctic Sweden, Koehler et al., 2014). To understand why sunlight can be an important control on DOM degradation in these systems, we review controls on DOM photodegradation and the specific characteristics of thermokarst lakes that can maximize opportunities for photodegradation.

Sunlight breaks down DOM into three broad classes of products: (1) $\mathrm{CO}_{2}$ (and $\mathrm{CO}$ that can be subsequently oxidized to $\mathrm{CO}_{2}$; photo-mineralization), (2) partially oxidized or degraded DOM that bacteria can then readily respire to $\mathrm{CO}_{2}$ (photo-stimulated bacterial respiration), and (3) partially oxidized or degraded DOM that is more recalcitrant to bacteria (Alaska, Cory et al., 2010, 2013, 2014; Hong et al., 2014; Canadian High Arctic, Laurion and Mladenov, 2013). Where the presence of thermokarst increases the transfer of old permafrost carbon from land to water, photochemical conversion of DOC to $\mathrm{CO}_{2}$ and photo-stimulated bacterial respiration may therefore increase old $\mathrm{C}$ transfer to the atmosphere. This occurs on relatively short time scales (e.g. months to decades), thus providing a positive climate effect with respect to global warming (e.g. Cory et al., 2013, 2014; Laurion and Mladenov, 2013). The water column rate of DOM photodegradation to $\mathrm{CO}_{2}$ or to partially oxidized DOM increases with increasing UV radiation, and also depends on the rate of light absorption by DOM in the water column, and the lability of DOM to be converted to $\mathrm{CO}_{2}$ or to partially oxidized DOM during light exposure.
UV irradiance entering the water column depends on the extent and presence of snow and ice cover (Vincent and Belzile, 2003), the solar zenith angle (i.e. latitude, date and time of day), and the composition of the atmosphere (e.g. ozone, and the amount and type of clouds and aerosols) (Vavrus et al., 2010; Bernhard et al., 2013). In surface waters across the Alaskan Arctic (from Toolik Lake to Barrow, $\mathrm{AK})$, the sun is above the horizon from approximately midMay through mid-July, but $\sim 90 \%$ of the daily UV flux involved in DOM degradation reaches surface waters during the day due to the low solar zenith angle overnight (Alaska, Cory et al., 2014). Clouds generally decrease surface UV, but the effect of clouds can be offset by ozone levels, making it difficult to predict surface UV based only on latitude and date across the Arctic (Vavrus et al., 2010; Bernhard et al., 2013). Although less UV generally reaches surface waters in the Arctic compared to lower latitudes due to lower solar zenith angles, thermokarst lakes and ponds can often have high concentrations of light-absorbing DOM that is susceptible to photo-degradation, thus potentially counter-balancing the lower UV (Alaska, Cory et al., 2014; sub-Arctic Sweden, Koehler et al., 2014).

The many shallow ponds and lakes across the Arctic often contain high concentrations of light-absorbing CDOM (e.g. Alaska, Hobbie, 1980; NW Canada, Gareis et al., 2010; sub-Arctic Québec, Watanabe et al., 2011; Alaska, Cory et al., 2014) as is consistent with high concentrations of lightabsorbing DOC draining from soils surrounding these lakes (Alaska, Judd et al., 2007; Merck et al., 2012; NE Siberia, Frey et al., 2015). For example, absorption coefficients for CDOM were reported to range from $9-17 \mathrm{~m}^{-1}$ at $330 \mathrm{~nm}$ in lakes of the Mackenzie Delta (Gareis et al., 2010), while a survey of 380 lakes in the Alaskan Arctic reported a mean of $11 \mathrm{~m}^{-1}$ vs. $31 \mathrm{~m}^{-1}$ at $320 \mathrm{~nm}$ for lakes near the foothills of the Brooks Range vs. lakes on the coastal plain, respectively (Cory et al., 2014). For small sub-Arctic thermokarst lakes at the southern limit of permafrost along the eastern Hudson Bay, Watanabe et al. (2011) present a large range of absorption coefficients at $320 \mathrm{~nm}\left(9.9\right.$ to $\left.56 \mathrm{~m}^{-1}\right)$ at the southern limit of permafrost along eastern Hudson Bay, while even a wider range was obtained by Breton et al. (2009) in the same region (reaching up to $171 \mathrm{~m}^{-1}$ ), although these systems are typically also affected by high levels of non-CDOM UV absorbance (see below).

Near-surface rates of DOM photodegradation increase linearly with increasing CDOM, while the depth-integrated rates of photodegradation in the water column depend nonlinearly on CDOM concentrations due to the attenuation of light (Miller, 1998). In thermokarst lakes and ponds, CDOM is often the main UV-absorbing constituent (e.g. Hobbie, 1980; Gareis et al., 2010; Cory et al., 2014), and thus controls the depth of UV light penetration. However, non-algal particles and especially fine inorganic particles can contribute a significant portion of UV attenuation in thermokarst lakes influenced by marine clays and silts (Watanabe et al., 2011). 
In such cases, UV is attenuated to a much larger extent, limiting photochemical reactions to the very surface under the strongly stratified conditions observed for these systems (Laurion et al., 2010). Although CDOM concentrations, and thus light attenuation, are often high in lakes and ponds across the Arctic, the whole water column can still be exposed to UV because many of these systems are shallow (Gareis et al., 2010; Cory et al., 2014; see also Sect. 2.1). For example, a survey of CDOM and UV light in thermokarst lakes of the Mackenzie River delta concluded that $19 \%$ and $31 \%$ of the water column was exposed to UVB and UVA radiation, respectively (Gareis et al., 2010). For a series of thermokarst lakes and ponds of the coastal plain in the Alaskan Arctic, up to $20 \%$ of the water column was exposed to UVB while 30-100\% was exposed to UVA (Cory et al., 2014). Exceptions include turbid streams, ponds, and lakes impacted by thermokarst slumping (Bowden et al., 2008; Gareis et al., 2010; Watanabe et al., 2011; Cory et al., 2013), or ponds with abundant macrophyte production (Gareis et al., 2010), where UV penetration is low.

The degree to which DOM drained from catchment soils underlain by permafrost is susceptible to photodegradation, quantified as the apparent quantum yield for each major class of DOM photo-products, has been measured to be on the high end of the range reported for aquatic DOM (Alaska, Cory et al., 2013, 2014; Hong et al., 2014; sub-Arctic Sweden, Koehler et al., 2014). These findings suggest that DOM originating from soils underlain by permafrost may be more labile to photodegradation relative to DOM in freshwaters outside the Arctic, consistent with prior studies showing a high photo-reactivity of DOM in Arctic surface waters (NE Siberia, Mann et al., 2012; Canadian High Arctic, Laurion and Mladenov, 2013) that is suggested to increase downstream in the network (Frey et al., 2015). However, DOM leached specifically from the permafrost soil layer sampled across the Arctic has a consistently lower concentration of aromatic, light absorbing carbon (i.e. lower CDOM per DOC concentration), often quantified as lower $\mathrm{SUVA}_{254}$ values (Mann et al., 2012; Cory et al., 2013, 2014; Abbott et al., 2014; Ward and Cory, 2015), compared to DOM draining from the active, organic surface layer. Despite lower concentrations of light-absorbing $\mathrm{C}$, permafrost DOM has been measured to be equally or more sensitive to photodegradation in a series of sites in the Alaskan Arctic (i.e. when comparing apparent quantum yields for photochemical $\mathrm{CO}_{2}$ production for example, corrected for differences in rates of light-absorption; Cory et al., 2013). These results may suggest that the chemical composition of permafrost DOM makes it more reactive to sunlight than expected based on aromatic $\mathrm{C}$ content alone.

Overall, the typical range of CDOM concentrations and the shallow water depths in thermokarst lakes and ponds can mean that a greater fraction of DOM is exposed to UV in the water column compared to deeper, non-thermokarst lakes. Especially for lakes and ponds with no outlet, the res- idence time of DOM and its exposure to UV light is high, thus confining DOM to a thin boundary layer where opportunities for photodegradation are maximized (e.g. Alaska, Lougheed et al., 2011; sub-Arctic Sweden, Olefeldt and Roulet, 2012). The alternation of stratification periods (intensive UV exposure at the very surface) with night-time cooling and mixing (renewal of surface water DOM) observed in many shallow thermokarst lakes may also offer a greater opportunity for efficient DOM photodegradation. With forthcoming climate change and deeper permafrost thaw, C flux from peaty soils to thermokarst lakes may also be enhanced in some regions, and the released DOM will be subject to UV-induced mineralization, especially as the summer season lengthens (Erickson III et al., 2015). On the other hand, a study of 73 lakes in the Mackenzie Delta uplands found that slump-impacted lakes had significantly lower CDOM than un-impacted lakes (Kokelj et al., 2009; Thompson et al., 2012; see Sect. 2.2), indicating that photodegradation may decline in some slump-impacted systems due to adsorption of $\mathrm{CDOM}$ to basic cations and clay particles. A strong response in UVB attenuation to small changes in CDOM was observed in lakes of NW Finnish Lapland, suggesting that even minor shifts in CDOM may greatly change the UV radiation exposure of high-latitude lakes, with likely consequences on the photochemistry and biota (Forsström et al., 2015). To understand the role of sunlight in DOM processing in thermokarst waters, future work must quantify UV irradiance in the water column, residence time of DOM in the UV-exposed portion of the water, and identify the factors that control vertical losses of DOM and the lability of permafrost DOM to photodegradation.

\subsection{Photochemical and microbial transformation of contaminants}

There are likely to be multiple effects of permafrost thaw on the mobility and transformation of contaminants in Arctic environments. The climate-triggered release of contaminants may increase contaminant transport into aquatic systems through increased leaching and hydrological connectivity. Thermokarst lakes with anoxic sediments may cause the remobilization of contaminants, and may also allow enhanced microbial activity and hypolimnia, and bacterial metal alkylation in the hypolimnion (e.g. production of the neurotoxin methylmercury). Here, we examine the potential mechanisms that may allow Arctic warming to lead to increases in the degradation and transformation of contaminants.

Photochemical transformations may affect both the mobility and availability of photoreactive contaminants such as the DOC-driven photoredox transformations of As (Buschmann et al., 2005) and Hg. Tseng et al. (2004) showed that $\mathrm{Hg}$ can be photoreduced and volatilized in Alaskan surface waters, whereas the neurotoxin methylmercury in the same region can be photodegraded (Hammerschmidt and Fitzgerald, 
2010). Photochemical transformation of contaminants may become more important in regions where the total area of non-turbid thermokarst ponds is increasing, as these shallow ecosystems are irradiated constantly during the polar summer (e.g. Mann et al., 2014).

Changes in the release of DOC and POC into aquatic ecosystems may significantly affect the phase partitioning and solubility of contaminants. In discontinuous permafrost regions, an increase in labile organic carbon (i.e. DOC) with thawing may lead to enhanced microbial activity and hence alter the microbial transformation of some contaminants (Roehm et al., 2009). Microbes can influence contaminant cycling by degrading organic contaminants, alkylating metals, and creating redox gradients that may modify the mobility and toxicity of toxic metals. Permafrost thaw can affect microbial diversity and microbial activity. Microbial diversity typically is highest in the surface active layer and decreases towards the permafrost table (NW Canadian Arctic, Frank-Fahle et al., 2014), hence deepening of the active layer will likely modify microbial diversity. Changing microbial diversity in combination with nutrient and temperature effects can affect the microbial degradation of organic pollutants in thawing permafrost (Bell et al., 2013). Microbial activity can be enhanced when permafrost thaw creates new environments such as warm, stratified thermokarst lakes, which may be potential sites for bacterial metal alkylation (Stern et al., 2012) such as found in two regions of NW Canada (MacMillan et al., 2015). Thermokarst lakes with hypoxic or anoxic bottom waters may be sites that are highly conducive to microbial $\mathrm{Hg}$ (II) methylation, and increasing inputs of organic matter and nutrients from thawing permafrost into these systems may have potentially important consequences for the transport or in situ production of methylmercury (MacMillan et al., 2015).

Manasypov et al. (2014) showed that thermokarst lakes in Siberia have close relationships between diagenetic processes and the remobilization of contaminants from the sediments. This remobilization is tied to diagenetic reactions occurring in these lakes due to the microbial mineralization of natural organic matter. The anoxic conditions in lake sediments during the early stages of thermokarst lake development result in microbe-mediated reactions causing authigenic sulphide precipitation (i.e. the reduction of sulphate) that can create a sink for metals in the sediments (western Siberia, Audry et al., 2011). Early diagenetic reactions in Siberian thermokarst lakes and the resulting shift in redox conditions are responsible for the partitioning of trace elements, including several major contaminants (As, $\mathrm{Cu}, \mathrm{Zn}$, $\mathrm{Cd}, \mathrm{Pb}, \mathrm{Ni}$ ). During all stages of lake development in this region, the sediments may be a source of dissolved $\mathrm{Ni}$ and As to the water column (Audry et al., 2011).

As outlined in Sect. 2.2.6, permafrost thaw may initially lead to a higher mobility of organic and inorganic contaminants into aquatic systems across different Arctic regions. For instance, peat leaching leads to higher levels of dis- solved trace metal concentrations in Siberian thermokarst lakes (Manasypov et al., 2014). However, the bioavailable metal pool will ultimately be controlled not only by the importance of the dissolved fraction, but also by chemical and biological changes, such as photodegradation and organic matter complexation. For inorganic contaminants, the quantity, quality, and molecular weight of organic matter being released, photolyzed, and microbially transformed from thawing permafrost during thermokarst lake evolution is likely a key driver of metal bioavailability in these systems (Pokrovsky et al., 2011).

\subsection{Microbiology of thaw waters}

Biogeochemical data collected to date from thermokarst lakes, rivers, ponds, and wetlands point to the importance of these environments as sites of intense microbial activity in the northern landscape. As a result there is an increasing effort to apply molecular microbiological methods, particularly next generation nucleic acid sequencing techniques, to understand the biodiversity, network relationships, and biogeochemical capabilities of these microbial communities. This research theme is still at an early stage of development, but the picture that is emerging is one of complex microbial consortia, with all domains of life well represented, and dominance by certain groups that play key biogeochemical roles (e.g. Negandhi et al., 2013; Crevecoeur et al., 2015; Przytulska et al., 2015).

Methanogenic archaea occur in high abundance in the anoxic, $\mathrm{CH}_{4}$-rich waters of permafrost thaw waters and wetlands, and molecular techniques have revealed a variety of taxa. In the Canadian High Arctic, gene signatures from acetoclastic and hydrogenotrophic methanogenic Archaea were detected in ponds associated with ice-wedge polygons (Negandhi et al., 2013), while Mondav et al. (2014) showed across a permafrost gradient in northern Sweden that partially thawed sites were often dominated by a single taxon (Methanoflorens stordalenmirensis) that belongs to the uncultivated archaeal lineage "Rice Cluster II". Metagenomic analysis showed that this micro-organism has the genes for hydrogenotrophic methanogenesis. A subsequent molecular study by McCalley et al. (2014) in sub-Arctic Sweden combined with isotopic analyses showed that the abundance of this taxon is a predictor of the relative proportions of carbon released from the thawing permafrost as $\mathrm{CH}_{4}$ vs. carbon $\mathrm{CO}_{2}$.

There is now a rapidly growing DNA data base for bacteria in permafrost soils, which often contain anaerobic groups such as sulphate reducers, Fe(III) reducers, and denitrifiers, and many aerobic groups including actinobacteria and methanotrophs (Jansson and Tas, 2014). By comparison, much less is known about the microbial constituents of thaw waters. Soil crusts in the High Arctic polar desert have been shown to contain remarkably diverse communities of bacteria, with evidence that their populations of cyanobacteria and 
acidobacteria are stimulated by water track flows over the permafrost (Steven et al., 2013). High throughput analysis of bacterial samples from High Arctic ponds showed that the planktonic sequences in these waters were dominated by carbon degrading taxa in the Bacteroidetes, Betaproteobacteria and Actinobacteria (Negandhi et al., 2014). In contrast, the sediment community had a higher alpha-diversity and the sequences included carbon degraders (29-46\%), cyanobacteria $(20-27 \%)$, purple non-sulfur bacteria (6-13\%), methanotrophs (11-20\%), and methanogen symbionts (1-2\%).

DNA clone library analysis of thermokarst lakes in a sporadic permafrost region in sub-Arctic Québec revealed large differences in the assemblages inhabiting the different water layers, and the presence of methanotrophic bacteria (Rossi et al., 2013). Subsequent analysis of lake communities in the same region by high throughput RNA sequencing showed that the dominant bacterial taxa were beta-proteobacteria, especially the genera Variovorax and Polynucleobacter (both known to degrade a wide variety of organic compounds), and that methanotrophs (notably Methylobacter) were also well represented (Crevecoeur et al., 2015). Methanotrophic taxa accounted for up to $27 \%$ of the total bacterial sequences, indicating the importance of $\mathrm{CH}_{4}$ as an energy source in these ecosystems. A puzzling observation was that the anoxic bottom waters in most of these thermokarst lakes had abundant methanotrophs, accounting for up to $23 \%$ of the sequences. This could be the result of intermittent injection of oxygen into these bottom waters by mixing, or sustained viability of the methanotrophs mixed down from the aerobic surface zone. Such mixing occurs mostly during autumn in these subArctic lakes (Deshpande et al., 2015), which would imply prolonged survival under anoxic conditions, and the availability of an inoculum for rapid response to oxygen resupply during mixing. However, few data are available from thermokarst lakes further north, and it is not known whether these sub-Arctic patterns occur elsewhere. A major unknown for thermokarst lakes throughout the sub-Arctic and Arctic is the composition of winter microbial communities beneath the ice, and this will require close attention in the future.

High-throughput DNA sequencing has also been used to examine biogeographical patterns. The bacterial composition of thermokarst lakes examined over a north-south gradient of permafrost degradation in sub-Arctic Québec showed that greater differences occurred among valleys across this gradient than among lakes within a valley, despite marked differences in limnological properties among neighbouring lakes (Comte et al., 2015). This implies that the taxonomic composition and perhaps also the biogeochemical functioning of thermokarst lake bacterial assemblages are regulated by local landscape features, such as the extent of permafrost thaw.

Phototrophic organisms in thaw waters include photosynthetic sulphur bacteria (sub-Arctic Québec, Rossi et al., 2013; Crevecoeur et al., 2015), benthic cyanobacteria, purple non-sulphur bacteria (Canadian High Arctic, Negandhi et al., 2014), and picocyanobacteria, as well as eukaryotic algae of diverse phylogenetic groups (sub-Arctic Québec, Przytulska et al., 2015); however the network associations among these organisms and other microbial taxa are yet to be explored. Such analyses have been applied to temperate lake communities, combining bacterial DNA sequence data with phytoplankton and zooplankton counts by microscopy, and these reveal highly connected, potential keystone taxa in the mixed communities (Peura et al., 2015).

Large Arctic river systems receive thaw waters from throughout their catchments and can serve to monitor largescale patterns. Crump et al. (2009) reported that bacterial communities showed a large spatial synchrony, along with clear seasonal community differences driven by shifts in hydrology and biogeochemistry that reassembled annually. Furthermore, Crump et al. (2012) observed a decreasing species diversity downslope in a soil-stream-lake sequence in Alaska. Soil waters and headwater streams showed the highest species richness, whereas lake waters show a lower diversity. They suggest that bacterial and archaeal diversity in freshwaters is initially structured by inoculation of soil microbes, and then subject to a species-sorting process during downslope dispersal. Permafrost thaw could lead to a greater transfer of soil microbes into aquatic communities.

A conspicuous gap in information available to date is the diversity and role of viruses in these microbe-rich habitats. Viruses are likely to be the biologically most abundant particles in these waters, as elsewhere, and may influence the species succession of microbes in all domains of life, affect carbon cycling by their lytic activities, and have a controlling influence on evolutionary processes via horizontal gene transfer (Suttle et al., 2007). New viral lineages are being discovered in environments elsewhere (e.g. freshwaters in the Canadian High Arctic, Chénard et al., 2015), and thermokarst lakes and ponds will likely yield additional new groups given the diversity of potential host taxa.

\subsection{Aquatic gas fluxes}

\subsubsection{Emission of $\mathrm{CO}_{2}$ and $\mathrm{CH}_{4}$ from permafrost-thaw-impacted systems}

In well-drained terrestrial environments, permafrost thaw leads to microbial decomposition resulting in variable production and emission of $\mathrm{CO}_{2}$ (e.g. Schuur et al., 2009; Schädel et al., 2014). Thaw of ice-rich permafrost, particularly in poorly drained lowland areas, results in ground subsidence and saturated soils that take the form of thermokarst lakes, wetlands, and slumping into streams. Since waterlogging slows the diffusion of oxygen from the atmosphere into soils, this results in anoxic conditions in sediments as well as in portions of the overlying water columns of many thermokarst water bodies. Under anaerobic conditions, decomposition of organic matter also produces $\mathrm{CH}_{4}$ (e.g. Alaska, Wickland et al., 2006). Where soils surrounding thermokarst lakes are anoxic, lateral inputs of $\mathrm{CH}_{4}$ produced 
within the active layer can also occur (Alaska, Paytan et al., 2015). Work in northern Siberia suggests that small water bodies may be particularly important for $\mathrm{CO}_{2}$ and $\mathrm{CH}_{4}$ emissions (Repo et al., 2007; Abnizova et al., 2012). In a study on northern Ellesmere Island, Canada, desert soils consumed $\mathrm{CH}_{4}$ during the growing season, whereas the wetland margin emitted $\mathrm{CH}_{4}$, with an overall positive $\mathrm{CH}_{4}$ flux over the landscape using, varying with soil temperature (Emmerton et al., 2014). The $\mathrm{CH}_{4}$ flux varied closely with stream discharge entering the wetland and hence the extent of soil saturation.

In a study of 40 Alaskan thermokarst lakes (Fig. 5) that span large gradients of climate, vegetation, geology, and permafrost regimes, Sepulveda-Jauregui et al. (2015) found that all lakes were net sources of atmospheric $\mathrm{CH}_{4}$ and $\mathrm{CO}_{2}$ (when integrated over a year) as also noted earlier by Kling et al. (1991, 1992). On a C mass basis, $\mathrm{CO}_{2}$ emissions from Alaskan lakes were $\sim 6$-fold higher than $\mathrm{CH}_{4}$ emissions. However, considering the $\sim 30$-fold stronger global warming potential of $\mathrm{CH}_{4}$ vs. $\mathrm{CO}_{2}$ over 100 years $\left(\mathrm{GWP}_{100}\right.$; Myhre et al., 2013), $\mathrm{CH}_{4}$ emissions had nearly twice the impact on climate as $\mathrm{CO}_{2}$ emissions in this region.

In the eastern Canadian Arctic, a thermokarst lake (deep enough to have unfrozen water in winter and likely a talik underneath) was shown to be a relatively small GHG emitter in July (Bouchard et al., 2015), although its thermal structure suggests that GHG potentially stored in the hypolimnion is transferred to the atmosphere at the autumnal overturn. Large variations in summertime $\mathrm{CO}_{2}$ and $\mathrm{CH}_{4}$ fluxes were shown in smaller lakes and ponds from two sites located in the Canadian sub- and High Arctic (Laurion et al., 2010). Turbid, subArctic thermokarst lakes were all GHG emitters, but showed on average a 530-fold higher $\mathrm{CO}_{2}$ than $\mathrm{CH}_{4}$ diffusive flux in summer, with strong GHG gradients in the hypolimnion (summer storage). In the High Arctic, polygonal ponds over low-centred ice wedge polygons were $\mathrm{CO}_{2}$ sinks because of colonization by active cyanobacterial mats (Laurion et al., 2010), while shallower ice-wedge trough ponds were identified as the main GHG emitters (Negandhi et al., 2013), with summer $\mathrm{CO}_{2}$ fluxes $\sim 25$-fold higher than $\mathrm{CH}_{4}$ diffusive flux. At this site, the $\mathrm{CH}_{4}$ ebullition flux (likely background ebullition) was in the same range as the diffusive flux (Bouchard et al., 2015).

In streams and rivers, emission of $\mathrm{CO}_{2}$ is typically much greater than emission as $\mathrm{CH}_{4}$ (Yukon River, Alaska, Striegl et al., 2012). On a catchment scale, sub-Arctic and Arctic streams within permafrost zones can emit relatively high amounts of GHG relative to their areal extent (sub-Arctic Québec, Teodoru et al., 2009; Alaska, Striegl et al., 2012; Siberia, Crawford et al., 2013; Denfeld et al., 2013; subArctic Sweden, Lundin et al., 2013), and gaseous emissions can account for up to $50 \%$ of total C exports (Striegl et al., 2012). For example, in northern Sweden, streams accounted for $4 \%$ of the aquatic surface area yet accounted for $95 \%$ of the total aquatic emissions (Lundin et al., 2013), whereas in northern Québec, streams accounted for $1 \%$ of the aquatic surface and accounted for $25 \%$ of the aquatic emissions (Teodoru et al., 2009). Stream $\mathrm{CH}_{4}$ emissions can also be significant to total catchment emissions; for example in interior Alaska stream $\mathrm{CH}_{4}$ emission was estimated to be up to $10 \%$ of catchment terrestrial emissions despite the very low surface area $(<0.2 \%$ of catchment area; Crawford et al., 2013). The relatively high emissions can be attributed both to supersaturation relative to the atmosphere as well as high gas transfer velocities associated with these more turbulent waters (Kling et al., 1992; Striegl et al., 2012; Denfeld et al., 2013; Lundin et al., 2013). To date, however, there are no published studies to show how gas fluxes are affected by the direct action of thermokarst slumping into streams.

A global-scale database of 4902 lakes have previously shown a significant relationship between DOC and $\mathrm{CO}_{2}$ (Sobek et al., 2005). This relationship has also been shown for a smaller set of Arctic and sub-Arctic thermokarst lakes in Canada, especially for the chromophoric fraction of DOM (Laurion et al., 2010). Sepulveda-Jauregui et al. (2015) also found a significant relationship between $\mathrm{CH}_{4}$ diffusive flux and phosphorus concentrations in a series of thermokarst lakes over a N-S Alaska transect. Therefore, we can assume that when thermokarst slumping leads to an associated increase in DOM and nutrients, we can expect an overall rise in GHG emissions from aquatic systems.

\subsubsection{Scale and distribution of GHG measurements}

Since the solubility of $\mathrm{CO}_{2}$ exceeds that of $\mathrm{CH}_{4}, \mathrm{CO}_{2}$ evades aquatic ecosystems primarily by diffusion, while $\mathrm{CH}_{4}$ more readily comes out of solution, forming bubbles in sediments that escape to the atmosphere by ebullition. Emission of $\mathrm{CH}_{4}$ through diffusion from aquatic systems can, however, also be high, particularly in wetlands, lakes, and other standing open water (Alaska, Reeburgh et al., 1998; sub-Arctic Sweden, Lundin et al., 2013). Due to large heterogeneity in the spatial and temporal dynamics of ebullition, this mode of $\mathrm{CH}_{4}$ emission is less commonly studied than diffusion (Bastviken et al., 2011; Wik et al., 2015), although ebullition has been found to be the dominant form of $\mathrm{CH}_{4}$ emission in many thermokarst lakes (Bartlett et al., 1992, Walter et al., 2006; Sepulveda-Jauregui et al., 2015; see also discussion on the eastern Canadian Arctic, above). Recent studies focusing on ebullition dynamics in thermokarst lakes distinguished multiple sub-modes of ebullition emission, including seep ebullition, background ebullition, and ice-bubble storage (Alaska and Siberia, Walter et al., 2006; Greene et al., 2014; Langer et al., 2015; Sepulveda-Jauregui et al., 2015; Fig. 5). Background ebullition is most commonly reported in the literature and consists predominately of distributed bubbling from seasonally warm surface sediments. In contrast, seep ebullition involves bubbling of $\mathrm{CH}_{4}$ formed at depth in dense sediments (Fig. 4), which are typically found in thaw bulbs beneath thermokarst lakes and streams (Walter Anthony et al., 2014). Seep ebullition occurs repeatedly 

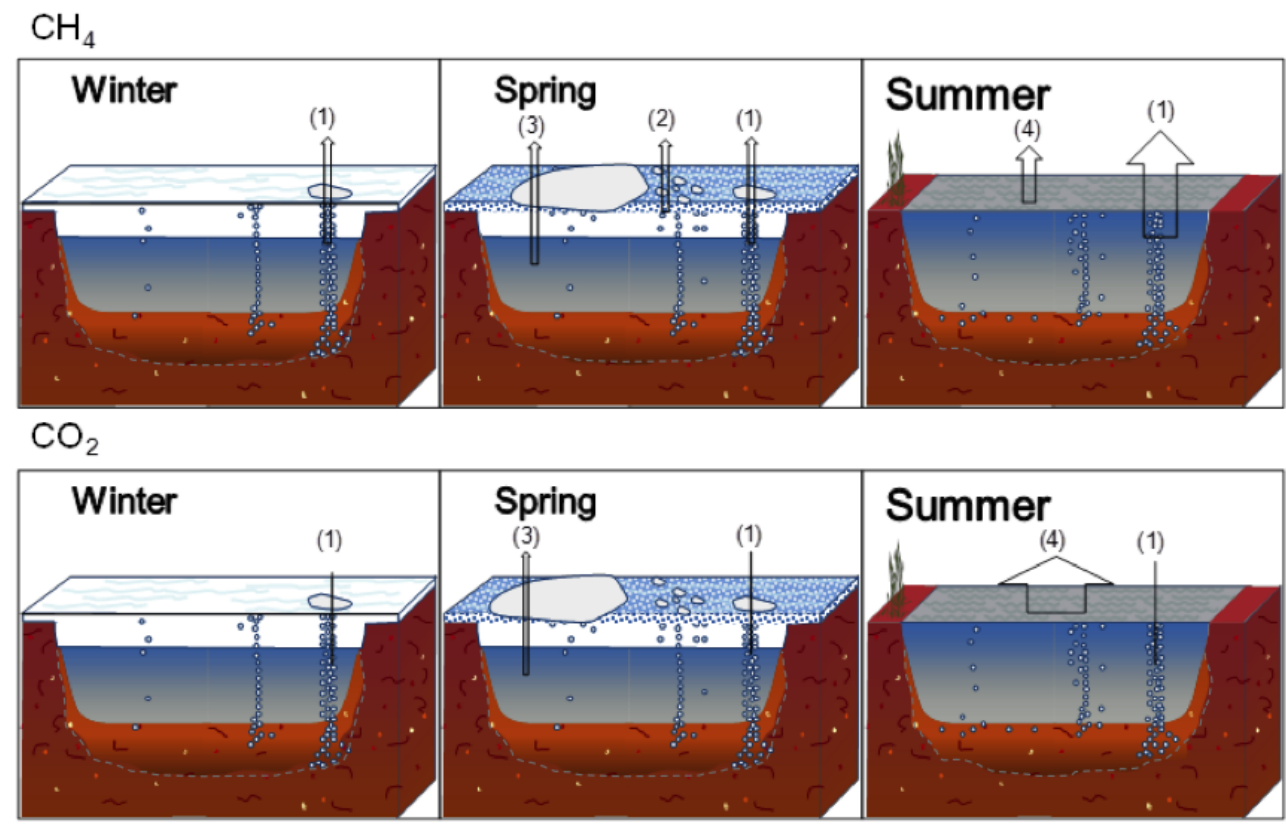

Figure 5. Schematic of $\mathrm{CH}_{4}$ and $\mathrm{CO}_{2}$ emission pathways during different seasons in thermokarst lakes. The thickness of arrows indicates the relative magnitude of contribution from each pathway according to a study of 40 Alaskan lakes (Sepulveda-Jauregui et al., 2015): (1) direct ebullition through ice-free hotspot seeps in winter and from all seep classes during the last month of ice cover in spring and in summer; (2) ice-bubble storage emission during spring ice melt; (3) storage emission of dissolved gases accumulated under lake ice when ice melts in spring; (4) diffusion emission from open water in summer. The background ebullition mode, discussed in the text, is not shown. The dashed line indicates the boundary between the thaw bulb under lakes and the surrounding permafrost. Figure modified from Sepulveda-Jauregui et al., 2015 .

from the same point-source locations and occurs year-round due to the thermal lag that results in warmer temperatures in deep sediments through autumn to winter. Bubbling rates in hotspot seeps are high enough to maintain open holes in thermokarst lake ice, resulting in the emission of $\mathrm{CH}_{4}$-rich bubbles to the atmosphere throughout winter (Zimov et al., 2001; Greene et al., 2014; Fig. 5). In thermokarst lakes where both seep and background ebullition were measured, seep ebullition was found to dominate $\mathrm{CH}_{4}$ emissions despite occupying only a small fraction of the lake surface area (Walter et al., 2006). More recently, ice-bubble storage, the release of ebullition bubbles seasonally trapped by winter lake ice upon spring melt, was also recognized as an important, additional mode of ebullition. It contributed $9-13 \%$ of total annual $\mathrm{CH}_{4}$ emissions from thermokarst (and non-thermokarst) lakes in Alaska (Greene et al., 2014; Sepulveda-Jauregui et al., 2015) and was also recognized as an important springtime emission mode in west Siberian lakes (Golubyatnikov and Kazanstev, 2013). Ice-bubble storage is likely an important mode of emission in many Arctic systems since $\mathrm{CH}_{4}$ rich ice-bubbles have been observed in aquatic systems in northeast Siberia (Walter et al., 2006; Langer et al., 2015), Sweden (Wik et al., 2011; Boereboom et al., 2012), Finland (Walter Anthony et al., unpublished data); Greenland (Walter Anthony et al., 2012), Alaska (Walter et al., 2007; Bro- sius et al., 2012; Sepulveda-Jauregui et al., 2015) and Canada (Duguay et al., 2002; Brosius et al., 2012).

One promising technique for measuring aquatic gas fluxes in permafrost-impacted systems is eddy covariance (EC), but $\mathrm{EC}$ data on inland freshwater ecosystems are still rare. Currently, on-going EC measurements focus on $\mathrm{CO}_{2}$ and $\mathrm{CH}_{4}$ fluxes over thermokarst lakes in Siberia (T. Sachs, personal communication, 2015; L. Belelli-Marchesini, personal communication, 2015) or sub-Arctic lakes within thawing permafrost environments (M. Jammet, personal communication, 2015). Using EC, Eugster et al. (2003) found efflux rates of $114 \mathrm{mg} \mathrm{C} \mathrm{m}^{-2} \mathrm{~d}^{-1}$ over an Arctic Alaskan lake in late July, which agreed well with two other continuous flux estimation techniques (boundary layer and surface renewal models). In a Swedish boreal lake, $\mathrm{CO}_{2}$ effluxes determined by episodic floating chamber measurements were about $100 \%$ larger than fluxes measured with EC, suggesting potential biases related to inadequate spatial and/or temporal sampling intervals of the chamber method (Podgrajsek et al., 2014a).

While proving the feasibility of EC measurements in freshwater ecosystems, aquatic EC work also highlights challenges related to the application of this terrestrially optimized approach to aquatic systems (Vesala et al., 2006; Eugster et al., 2011). Overall, EC shows great promise with respect to the following: (1) integration of all gas flux pathways from the lake sediments to the atmosphere; (2) continuous flux 
monitoring over time, enabling the capture of episodic ebullition events of $\mathrm{CH}_{4}$ in lakes (Eugster et al., 2011); and (3) the analysis of dynamic responses of lake-atmosphere carbon fluxes to temporal (including diurnal) changes in environmental variables (Eugster, 2003; Vesala et al., 2006; Podgrajsek et al., 2014b). A significant portion of gaseous carbon emissions from seasonally ice-covered lakes appears to occur during spring ice-thaw (e.g. Karlsson et al., 2013), stressing the importance of year-round carbon flux monitoring on thermokarst lakes.

\subsubsection{Lake morphology and evolution}

The morphological diversity of thermokarst lakes will have important consequences for hydrology, physicochemistry, and thus ultimately the microbial processes responsible for GHG production and evasion dynamics at the air-water interface. Within the context of permafrost soil organic carbon content, thermokarst lakes have been classified depending on whether they are surrounded by yedoma-type permafrost or non-yedoma substrates (Walter Anthony et al., 2012; Sepulveda-Jauregui et al., 2015). Yedoma is typically thick (tens of metres), Pleistocene-aged loess-dominated permafrost sediment with high organic carbon ( $\sim 2 \%$ by mass) and ice (50-90\% by volume) contents (Zimov et al., 2006). When yedoma thaws and ground ice melts, deep thermokarst lakes with high $\mathrm{CH}_{4}$ production potentials form (Zimov et al., 1997; Kanevskiy et al., 2011; Walter Anthony and Anthony, 2013). Because these deep ( $>2 \mathrm{~m}$ ) lakes are often humic and underlain by a talik, they are stratified for most of the year and are likely to have an anoxic hypolimnion controlling GHG producers and consumers. These systems present large GHG seepage ebullition throughout the year, with a characteristic seasonal pattern in GHG evasion (Walter et al., 2006; Sepulveda-Jauregui et al., 2015). Smaller but very turbid thermokarst lakes studied in the eastern coast of Hudson Bay also do not freeze to the bottom and can similarly be highly stratified and anoxic (Laurion et al., 2010; Deshpande et al., 2015).

Some non-yedoma permafrost soils can also have high organic carbon and excess ice concentrations within several metres of the ground surface; however, these organicand ice-rich permafrost horizons are typically thinner than yedoma deposits (Ping et al., 2008; Tarnocai et al., 2009; Bouchard et al., 2015). As a result, thermokarst lakes formed in non-yedoma permafrost soils are commonly shallower than yedoma lakes and have been shown to emit less $\mathrm{CH}_{4}$ (West and Plug, 2008; Grosse et al., 2013; Walter Anthony and Anthony, 2013). For instance, $\mathrm{CH}_{4}$ emissions from thermokarst lakes formed in carbon-rich yedoma permafrost were 6-fold higher than emissions from other lake types across Alaska (Sepulveda-Jauregui et al., 2015).

Shallow thermokarst lakes (e.g. Yukon, Turner et al., 2014) may allow colonization by plants and benthic photosynthesizing mats, creating $\mathrm{CO}_{2}$ sink periods while they remain
$\mathrm{CH}_{4}$ emitters (Mackenzie Delta, Tank et al., 2009; eastern Canadian High Arctic, Laurion et al., 2010; Negandhi et al., 2014). These lakes can freeze to the bottom (no talik, depending on latitude), which limits active GHG production to the unfrozen period of the year. In these shallow lakes there is less opportunity for the dissolution of ebullitive $\mathrm{CH}_{4}$ before it escapes to the atmosphere, and thus for its consumption by methanotrophic bacteria. Furthermore, large and shallow lakes are generally polymictic with GHG evasion largely influenced by winds, generating oxic conditions. For very small water bodies (a few $\mathrm{m}^{2}$ ) such as ice-wedge trough ponds, microtopography will be the main regulator of thermal structure, and gas exchange will be most affected by heat flux. Even though trough ponds are very shallow systems $(<1 \mathrm{~m})$, they can be highly stratified with only occasional mixing events during the summer (Bouchard et al., 2015), resulting in large periods of hypoxic to anoxic bottom waters, and evasion of GHG stored in bottom waters following changes in meteorological conditions. Depending on their erosional features these ponds can also be colonized by aquatic plants associated with efficient methanotrophic communities (e.g. Siberia, Liebner et al., 2011).

Finally, the evolution of thermokarst lake landscapes is a critical determinant of the overall carbon balance of these systems (van Huissteden et al., 2011; Walter Anthony et al., 2014). This landscape evolution can be observable at timescales on the order of 30-40 years (Smith et al., 2005; Bryksina et al., 2011; Polishuk et al., 2012) and is characterized by cyclical flooding of vegetated soils and recolonization of drained lake bottoms, and an evolution from strong $\mathrm{CH}_{4}$ emission during the initial phase of lake formation, through a phase of carbon accumulation associated with higher within-lake primary production and the creation of terrestrial wetlands as lakes drain (Ovenden, 1986; van Huissteden et al., 2011; Walter Anthony et al., 2014).

\section{Consequences}

\subsection{Release of old permafrost $\mathrm{OC}$ into aquatic systems and the atmosphere}

\subsubsection{Release of old permafrost $\mathrm{OC}$ into aquatic systems}

A recent study of Eurasian Arctic river basins by Feng et al. (2013) concluded that climate change-induced mobilization of old permafrost OC is well underway in the Arctic. In this section we review the evidence that currently exists for the release of old permafrost $\mathrm{OC}$ into aquatic systems.

Mobilization of old permafrost $\mathrm{OC}$ to surface waters could occur in the form of DOC, POC or gaseous $\mathrm{C}\left(\mathrm{CO}_{2}\right.$ or $\left.\mathrm{CH}_{4}\right)$. Release of old $\mathrm{C}$ can be measured with radiocarbon isotopes, either on bulk OC or on compound specific biomarkers. Since permafrost and Yedoma deposits contain organic 
C with ages of $>30000 \mathrm{yr} \mathrm{BP}$ (e.g. Zimov et al., 2006), radiocarbon could be an excellent marker to detect change in Arctic aquatic environments.

Research that includes bulk radiocarbon measurements in rivers has largely focused on DOC and POC. Generally, DOC in larger river systems tends to be young. In large Arctic rivers, Amon et al. (2012) and Guo et al. (2007) measured ${ }^{14} \mathrm{C}$-DOC values ranging from 83 to $113 \%$ modern $(1440$ to modern yr BP). Within large Arctic river basins there is significant spatial variability in riverine ${ }^{14} \mathrm{C}$-DOC values, reflecting dominant water and carbon source materials (Alaska, Aiken et al., 2014; O'Donnell et al., 2014). Export of contemporary DOC in rivers dominates the spring freshet, a time of year when the majority of water and DOC export occurs. In the $\mathrm{Ob}$, Yenisey, Lena, Mackenzie, and Yukon rivers, Raymond et al. (2007) estimated that $\sim 90 \%$ of DOC exported at this time was less than 20 years old. Later in the summer, DOC showed slight aging (675 yr BP, NE Siberia, Neff et al., 2006) which is likely related to OC input from deeper activelayer thaw. Winter flow is most ${ }^{14} \mathrm{C}$-depleted, although there can be significant variation within a large river basin even in winter. O'Donnell et al. (2014) measured winter radiocarbon ages ranging from 35 to $445 \mathrm{yr}$ BP, likely related to regional groundwater travel times.

Whilst major Arctic rivers mostly seem to export large amounts of young semi-labile DOC, there are also examples of mobilization of old DOC, particularly within smaller systems. In the Sagavanirktok River, draining north Alaskan tundra, DOC age was 2170-4950 yr BP (Guo et al., 2007). Soil organic matter in the river basin was of similar age, and likely released old DOC from the active layer and through soil cryoturbation. The oldest DOC ever dated in surface waters is from small (first-order) sediment-rich thaw streams draining directly into the Kolyma River, Siberia (Vonk et al., 2013; Spencer et al., 2015). This Pleistocene-aged (> $21000 \mathrm{yr} \mathrm{BP}$ ) DOC is being mobilized from old Yedoma deposits (aged up to $45000 \mathrm{yr} \mathrm{BP}$ ) into small DOC-rich streams. This old DOC also shows very high biodegradation potential (Vonk et al., 2013; Spencer et al., 2015; Sect. 3.1), indicating that it may be degraded to $\mathrm{CO}_{2}$ well before reaching the mouth of larger river systems (Kolyma River, Mann et al., 2015). Deep groundwater can also be a source of ancient DOC in large river systems (Yukon River, Aiken et al., 2014).

There is abundant evidence of mobilization of old POC into Arctic lakes (e.g. Canada, Abbott and Stafford, 1996), rivers, and estuarine sediments associated with permafrost thaw, bank erosion, and transport of organic C. For example, Guo et al. (2007) reported ${ }^{14} \mathrm{C}$ ages of sediment and suspended POC in large North American Arctic rivers of 4430 $7970 \mathrm{yr} \mathrm{BP}$ and concluded that POC release and age would increase in Arctic river systems subject to global warming. Additionally, there has been some work in smaller coastal watersheds in the Canadian High Arctic by Lamoureux and Lafrenière (2014) who concluded that recent permafrost disturbance delivered old (up to $6740 \mathrm{yr} \mathrm{BP}$ ) POC to the aquatic system. Yedoma-derived Pleistocene aged POC has also been identified in sediments from the Colville River delta, which drains into the west Beaufort Sea (Schreiner et al., 2014; $10000-16000 \mathrm{yr}$ BP), and in thaw streams draining Yedoma deposits, Siberia (Vonk et al., 2013; 19 000-38 000 yr BP). One caveat to studies in coastal or estuarine settings is that marine sediments and microfossils could potentially influence the ${ }^{14} \mathrm{C}$ age of particulate material.

Contrary to bulk measurements, compound-specific biomarkers can provide more source-specific information, and avoid many of the issues related to ${ }^{14} \mathrm{C}$ dating of bulk OC. Spencer et al. (2008) found elevated lignin Cnormalized yields during the spring freshet across the Yukon River basin, identifying surface vegetation as strong DOC sources. Amon et al. (2012) similarly found that biomarker abundance changed in six of the largest Arctic rivers according to season, with high concentrations of lignin phenols in the spring freshet (indicative of fresh vegetation) and elevated levels of p-hydroxybenzenes during the low flow season (indicative of moss and peat-derived OM). Concentration differences in source-tracing organic molecules, namely ${ }^{14} \mathrm{C}$-young, vascular plant-derived lignin phenols and ${ }^{14} \mathrm{C}$ old permafrost-derived waxy lipids, were found to show a relationship between ${ }^{14} \mathrm{C}$ age and permafrost coverage (Feng et al., 2013). Drainage basins associated with increasing amounts of discontinuous permafrost were characterized by older OC, released from deeper conduits in the watershed. Likewise Gustafsson et al. (2011) found that the average age of $n$-alkanes in estuarine sediments increased (1140 to $6400 \mathrm{yr}$ BP) from east to west across the Siberian Arctic, consistent with warmer climatic conditions and more discontinuous permafrost towards the west. Additional biomarkers such as membrane lipids (ex. glycerol dialkyl glycerol tetraethers, GDGTs; bacteriohopanepolyols, BHPs; and intact polar membrane lipids, IPLs) may have the potential to trace terrigenous OC stored in permafrost and remobilized along Arctic land-river-ocean transects (Rethemeyer et al., 2010; Doğrul Selver et al., 2012, 2015).

\subsubsection{Release of old permafrost $\mathrm{OC}$ as greenhouse gases}

The consequence of permafrost thaw beneath and adjacent to thermokarst lakes, wetlands, and streams is the potential mobilization and return of old carbon to the atmosphere. Schaefer et al. (2014) defined the permafrost carbon feedback as amplification of anthropogenic warming due to carbon emissions from thawing permafrost. Direct evidence for carbon emissions from thawing permafrost is found in the radiocarbon ages and deuterium values of $\mathrm{CH}_{4}$ in bubbles and in spatial patterns of $\mathrm{CH}_{4}$ emissions in thermokarst lakes. Zimov et al. (1997) first revealed that methanogenesis in deep, cold thaw bulbs where Pleistocene-aged yedoma is thawing beneath lakes in Siberia leads to the release of Pleistocene-aged $\mathrm{CH}_{4}$. The release of permafrost-derived carbon to the atmosphere in ${ }^{14} \mathrm{C}$-depleted $\mathrm{CH}_{4}$-rich bubbles 
contributes to climate warming, which in turn causes permafrost to thaw and more $\mathrm{CH}_{4}$ to be produced in a positive feedback cycle (Walter et al., 2006). Field observations and modelling showed that permafrost-derived $\mathrm{CH}_{4}$ emissions were highest along thermokarst margins in Siberian and Alaskan lakes, in younger stages of lake development where permafrost thaw is most active, and in small earlystage permafrost thaw depressions (Walter et al., 2006, 2007; Desyatkin et al., 2009; Kessler et al., 2012; Shirokova et al., 2013). This potential for permafrost thaw to augment climate change was affirmed in Alaskan thermokarst lakes by independent evidence from deuterium. Walter et al. (2008) and Brosius et al. (2012) found that $\delta \mathrm{D}$ values of ebullition $\mathrm{CH}_{4}$ in yedoma-type lakes in Alaska and Siberia reflected $\mathrm{CH}_{4}$ formation from Pleistocene-origin melt water, which has a highly negative isotopic signature. In contrast, bubbles emitted from the centres of older yedoma lakes where permafrost is no longer thawing (Alaska, Kessler et al., 2012), and from non-yedoma lakes, contained higher $\delta \mathrm{D}-\mathrm{CH}_{4}$ values and younger ${ }^{14} \mathrm{C}_{-} \mathrm{CH}_{4}$ ages, pointing to Holocene-aged meteoric water and carbon as the substrates for methanogenesis (Alaska, Brosius et al., 2012). On the other hand, recent work on an eastern Canadian thermokarst lake (Holocene deposits) shows a different trend, where ebullition $\mathrm{CH}_{4}$ emitted from the lakeshore was younger $(\sim 1550 \mathrm{yrBP})$ and had a more negative $\delta \mathrm{D}-\mathrm{CH}_{4}$ than from the lake centre ( $3250 \mathrm{yr}$ BP; Bouchard et al., 2015). Most interestingly, smaller thermokarst ponds at the same site emitted modern $\mathrm{CH}_{4}$ even though they are exposed to peat slumping and erosion down at least to the active layer (base of active layer $\sim 2,200$ to $2,500 \mathrm{yr} \mathrm{BP}$ ) with $\delta \mathrm{D}-\mathrm{CH}_{4}$ reaching down to $448 \%$ o (Bouchard et al., 2015).

It is important to note that the present-day effect of thermokarst lake evolution on climate warming is likely smaller than it was in the early Holocene when thermokarst lakes first formed on the permafrost landscape (Walter et al., 2007; Brosius et al., 2012). Walter Anthony et al. (2014) estimated rates of carbon loss from yedoma-type lakes (in north Siberia, Alaska and northwest Canada) to the atmosphere from $20 \mathrm{kyr}$ ago to the present. Their results indicate widespread lake formation between 14-9 kyr ago, generating a major northern source of ${ }^{14} \mathrm{C}$-depleted atmospheric $\mathrm{CH}_{4}$ during deglaciation. The subsequent slow-down of first-generation thermokarst-lake formation throughout the Holocene combined with the acceleration of other negative effects on global climate (e.g. carbon sequestration by lakes, see next section) results in lower present-day $\mathrm{CH}_{4}$ emissions, a smaller permafrost carbon climatic effect, and a net negative radiative forcing of carbon exchange between lakes and the atmosphere on climate.

\subsection{Carbon burial}

\subsubsection{Carbon burial in Arctic aquatic ecosystems}

Inland waters receive large quantities of organic matter from their watersheds, but, globally, less than half of this carbon reaches the ocean (Battin et al., 2009). The loss en route is attributed to (i) mineralization to $\mathrm{CO}_{2}$ and $\mathrm{CH}_{4}$ (see Sect. 3), and (ii) sequestration into sediments of lakes and reservoirs (Cole et al., 2007). Sediment sequestration of carbon can be substantial in relatively lake-rich boreal and Arctic landscapes (Lehner and Döll, 2004; Fig. 1), but still receives little attention.

Generally, total carbon mineralization rates exceed carbon burial (Battin et al., 2009; Tranvik et al., 2009), but there are some exceptions, for example in the case of deep thermokarst lakes (see Sect. 4.2.2). Lake shape is a key regulator of carbon burial; small and deep lakes (boreal Finland, Kortelainen et al., 2004; northern Québec, Ferland et al., 2012) bury carbon more efficiently than large and shallow lakes. This is explained by a higher benthic metabolic capacity to process incoming carbon and greater particle resuspension in large, shallow, and thus well-mixed lakes. Prior to burial, degradation occurs in the water column and the uppermost sediment layers. This can be substantial with, for example, averages up to $75 \%$ of the OC mineralized over the first few decades following sediment deposition in boreal lakes in Québec (Ferland et al., 2014). Long-term (century-scale to full Holocene) accumulation rates in sediments of Arctic and boreal nonthermokarst lakes ranged between 0.2 and $13 \mathrm{~g} \mathrm{C} \mathrm{m}^{-2} \mathrm{yr}^{-1}$ across sites in Greenland, boreal Québec, and boreal Finland (Anderson et al., 2009b; Ferland et al., 2014; Kortelainen et al., 2004; Sobek et al., 2014). Thermokarst lakes in yedoma regions, however, show much larger long-term sediment accumulation rates $\left(47 \pm 10 \mathrm{~g} \mathrm{C} \mathrm{m}^{-2} \mathrm{yr}^{-1}\right.$; Walter Anthony et al., 2014; see Sect. 4.2.2).

Similarly, coastal shelf regions bordering yedoma-rich eastern Siberia receive rather large amounts of carbon with accumulation rates of $36 \pm 17 \mathrm{~g} \mathrm{C} \mathrm{m}^{-2}$ annually (Vonk et al., 2012b). Long-term (Holocene) carbon accumulation rates in this region, however, vary between 0.1 and $2.7 \mathrm{~g} \mathrm{C} \mathrm{m}^{-2} \mathrm{yr}^{-1}$ (Stein and Fahl, 2000; Bauch et al., 2001) suggesting significant decomposition in the sediments after deposition and/or increases in recent accumulation rates. Furthermore, recent studies in this region suggest that permafrost-derived carbon is preferentially buried, when compared with marine or modern terrestrial carbon (Siberian shelf, Vonk et al., 2014). This appears to contrast with high initial biodegradability of (yedoma) permafrost DOC upon aquatic release (see Sect. 3.1). We hypothesize that this apparent contrast can be explained by the parallel thaw-release of different pools of organic matter in permafrost (Vonk et al., 2010; Karlsson et al., 2011). On the one hand, DOC and buoyant, non-mineral bound POC are released that are highly sensitive to biodegradation (e.g. NE Siberia, Vonk et al., 
2013; Alaska, Abbott et al., 2014) leading to rapid removal in aquatic systems (Spencer et al., 2015), whereas mineralbound, ballasted POC is resistant to degradation and preferentially transported to (and buried in) coastal shelf sediments (Karlsson et al., 2011; Vonk et al., 2011).

\subsubsection{Carbon burial in yedoma thermokarst lakes}

Since the last deglaciation (the past $14.7 \mathrm{kyr}$ ), about $70 \%$ of all yedoma deposits have thawed through the formation of thermokarst lakes and streams (Strauss et al., 2013). This has released GHG to the atmosphere and OC to lake basin sediments and downstream export. Formation of thermokarst systems, however, has also caused atmospheric $\mathrm{CO}_{2}$ to be absorbed through contemporary plant photosynthesis, senescence, and burial. While initial thermokarst basin formation caused significant efflux of $\mathrm{CO}_{2}$ and $\mathrm{CH}_{4}$ as these basins evolved, nutrient-rich sediments facilitated terrestrial and aquatic plant proliferation, leading to sequestration of $\mathrm{OC}$ in sediments of drained lake basins during the Holocene. The long-term organic carbon accumulation rate in deep, yedoma thermokarst lakes was found to be on average 5 times higher than in other northern lakes throughout the Holocene (Walter Anthony et al., 2014). The anomalously high carbon sequestration in yedoma thermokarst lakes was attributed to (a) thermokarst-related shore erosion and deposition of terrestrial organic matter in lake bottoms; (b) high aquatic productivity enhanced by nutrient supply from thawing yedoma; and (c) unique preservation conditions in deep thermokarst lakes.

Since GHG emissions and carbon sequestration have counteractive effects on climate (warming vs. cooling, respectively), the radiative impacts of both processes must be upscaled to understand their overall impact over long time scales. Walter Anthony et al. (2014) developed trajectories of thermokarst-basin carbon flux (for yedoma landscapes) from the last major glaciation to present, based on estimates of contemporary $\mathrm{CH}_{4}$ flux, total yedoma carbon lost as $\mathrm{CO}_{2}$ and $\mathrm{CH}_{4}$, total accumulated carbon, and thermokarst-lake initiation dates. Model results indicated that yedoma thermokarst lakes caused a net climate warming at the peak of their formation during deglaciation, driven primarily by $\mathrm{CH}_{4}$ release from thawed, decaying yedoma. However, high carbon accumulation in existing basins and a slowdown of lake formation caused thermokarst lake impact on climate to switch from net warming to net cooling around $5 \mathrm{ky}$ ago, such that these basins are now net GHG sinks. Notably, similar trajectories to describe the climatic effects of non-yedoma thermokarst lakes and ponds have not yet been extensively investigated, despite the fact that non-yedoma permafrost stores $75 \%$ of the global carbon permafrost pool (Zimov et al., 2006; Schuur et al., 2015).

\subsection{Ecosystem structure and function}

While there is a growing body of literature quantifying the nature, timing, and extent of permafrost thaw in the Arctic, there is considerably less literature on the direct effects of permafrost thaw on the structure and function of aquatic ecosystems, especially streams. The likelihood that permafrost thaw will substantially affect major ecological functions (e.g. photosynthesis, respiration, nutrient uptake) or food web characteristics (e.g. benthic algal biomass, macroinvertebrate community structure) is dependent on several factors, most notably the intensity, spatial extent, temporal duration, and hydrological connectivity of the disturbance associated with permafrost thaw. Here, we provide an overarching review of the potential effects of permafrost thaw on aquatic ecosystem structure and function.

\subsubsection{Lakes}

Arctic regions contain numerous lakes with large differences in abiotic and biotic conditions (Hamilton et al., 2001; Rautio et al., 2011), suggesting that the consequences of permafrost thaw on ecosystem function are likely to vary across systems. Thawing permafrost and associated changes in export of nutrients and DOM is expected to have pronounced effects on the productivity and food web dynamics of recipient lake ecosystems. Input of nutrients per se will increase primary production (mainly via effects on pelagic algae) (e.g. Alaska, Levine and Whalen, 2001 and O'Brien et al., 2005), yet input of sediments and DOM will decrease primary production if it leads to suboptimal conditions for photosynthesis, mainly affecting benthic algae but also planktonic algae when lakes are very turbid (northern Sweden, Ask et al., 2009; northern Québec, Roiha et al., 2015). In regions where thaw increases both nutrients and DOM we may expect stimulation of total primary production in clear and shallow lakes but suppression of primary production in more coloured or deeper lakes (Sweden and Alaska, Seekell et al., 2015). In regions where retrogressive thaw slumping delivers mineral-rich sediments to lakes (Mackenzie Delta uplands, Thompson et al., 2008 and Mesquita et al., 2010), permafrost degradation has led to significantly greater dissolved ion content, lower DOC concentrations following mineral adsorption, and increased water transparency. This has led to enhanced macrophyte development and higher abundance of benthic macroinvertebrates (Mackenzie Delta uplands, Mesquita et al., 2010 and Moquin et al., 2014) and higher abundance and diversity of periphytic diatoms (Mackenzie Delta uplands, Thienpont et al., 2013). Further, DOM released following thaw is relatively labile and could support bacterial metabolism (northern Sweden, Roehm et al., 2009; NE Siberia, Vonk et al., 2013), resulting in increasing rates of bacterial respiration and production relative to primary production (northern Québec, Breton et al., 2009 and Roiha et al., 2015; sub-Arctic Sweden, Karlsson et al., 2010). 
These changes at the base of the food web are expected to result in a shift in the relative importance of different OC resources supporting higher consumers, by decreasing the importance of benthic algae and increasing the reliance on pelagic and terrestrial resources with increasing DOM. Heterotrophic bacteria transfer DOM to mixotrophic algae and heterotrophic protozoans, to zooplankton and zoobenthos feeding on bacteria, and via predation to higher trophic levels (Jansson et al., 2007). Another consequence of thaw and increased DOM export is an increasing degree of net heterotrophy, i.e. a decrease in the ratio between gross primary production and community respiration (northern Sweden, Ask et al., 2012). Heterotrophic bacteria benefit from fresh and high carbon inputs from the catchment and the high nutrient concentrations below the thermocline (northern Québec, Breton et al., 2009; Roiha et al., 2015). Respiration rates can be very high in thermokarst lakes, favouring rapid oxygen depletion and prolonged anoxia (also northern Québec, Deshpande et al., 2015). This has implications for GHG production and exchange with the atmosphere (see Sect. 3.5). Oxygen depletion following permafrost thaw may also affect the resource supply and abundance of higher consumer populations. $\mathrm{CH}_{4}$-oxidizing bacteria, relatively abundant in many stratified thermokarst lakes (northern Québec, Crevecoeur et al., 2015), may play an important role in the carbon transfer through the food web. These bacteria are known to occur in environments where both oxygen and $\mathrm{CH}_{4}$ are available, and they have been suggested to contribute to the zooplankton diet (Jones, 2000; northern Finland, Kankaala et al., 2006). Permafrost thaw may stimulate this $\mathrm{C}$ pathway but it is not clear if this could override the likely negative effect on higher consumers by oxygen depletion (Craig et al., 2015; Karlsson et al., 2015).

\subsubsection{Streams}

In Sect. 2.2 we describe how permafrost thaw is likely to affect the delivery of sediment and nutrients to aquatic ecosystems. Sediment and nutrient concentrations are two of the fundamental factors that influence the structure and function of streams. However, as is the case with lakes, there is a trade-off between the negative effects (smothering, shading, and scouring) caused by elevated levels of sediment loading vs. the positive effects (fertilization) caused by elevated concentrations of soluble nutrients. Locally, and over the yearsto-decades timescale of TEF disturbance, if these features intersect a stream, they are likely to have significant impacts caused by massive inputs of sediment. While in some systems, TEFs have impacts that can be seen over broad catchment scales (e.g. NW Canada, Kokelj et al., 2013), in others, the long-term and regionally averaged effect of TEFs on suspended sediments may be relatively small (see Sect. 2.2). At the same time, ongoing active layer deepening (and longterm, deep impacts from older TEFs) may add low levels of nutrients to Arctic streams over longer time scales. Currently there is very little literature to support these potential impacts.

Even subtle increases in the loading of limiting nutrients can have profound impacts on highly oligotrophic, Arctic stream ecosystems. A whole-ecosystem nutrient fertilization experiment on the Kuparuk River has shown that long-term (30 years), low-level increases in soluble reactive phosphorus alone can have important influences on benthic autotrophic and macroinvertebrate community structure and can significantly increase primary and secondary production (Peterson et al., 1985; Bowden et al., 1994; Cappelletti, 2006). On the other hand, sediment loading may offset the stimulatory effects of introduced nutrients and interfere with benthic stream structure and function. Adverse effects of sediment influx to streams include damage to primary producers, especially from scour during storms, which can reduce primary production and ecosystem respiration. Increased sediment loading may clog the interstices among streambed particles, which could reduce the connectivity between the hyporheic zone and surface waters, interfering with exchange of nutrients and dissolved oxygen (Kasahara and Hill, 2006). Sediment loading may also lead to instability on the stream bottom, affecting the ability of benthic macroinvertebrates to establish and feed (Uehlinger and Naegeli, 1998).

Recent studies have evaluated the higher order effects of sediment and nutrient loading from thermokarst and detected significant impacts on some aspects of the biological function of receiving waters. Daily rates of riverine production and respiration decreased by 63 and $68 \%$, respectively, in the Selawik River in northwest Alaska in response to elevated turbidity levels that increased by several orders of magnitude below a massive thaw slump (Calhoun, 2012). Larouche et al. (submitted) studied biogeochemical characteristics of a tundra stream on the North Slope, Alaska over a period of three summer seasons (2009-2011) after a gully thermokarst feature impacted this stream several years earlier (2005). They found that 4-6 years after the initial disturbance the TEF still caused modest increases in the loading of sediment and dissolved solutes. Furthermore, rates of ecosystem production and respiration and benthic chlorophyll $a$ in the impacted reach of this stream, were significantly lower during the driest of the three summers. Rates of ammonium and soluble reactive phosphorus uptake were consistently lower in the impacted reach.

Benthic macroinvertebrates are typically the dominant vector of energy flow in stream ecosystems, connecting primary production to higher trophic levels (e.g. Hynes, 1970; Merritt et al., 2008). Species diversity of macroinvertebrate communities has been shown to be sensitive to minor disturbances in running waters (Lake, 2000), while allochthonous sediment has been shown to significantly impact habitat composition, leading to profound effects on the distribution of individual organisms (Alaska, Parker and Huryn, 2006). As discussed above, lakes affected by thaw slumps in the Canadian Arctic (Mackenzie Delta region) have been shown to 
have significantly greater dissolved ion content, lower DOC concentrations and increased water transparency (Thompson et al., 2008), that have in-turn led to enhanced macrophyte development and higher abundance of benthic macroinvertebrates (Mesquita et al., 2010; Moquin et al., 2014) and higher abundance and diversity of periphytic diatoms (Thienpont et al., 2013). We are not aware of any published studies that document impacts of thermo-erosional events on the benthic community structure of Arctic stream ecosystems. In the study conducted by Larouche et al. (2015) initial macroinvertebrate richness and diversity in Alaska was low but increased late in the season (August). Overall, the shifts in stream community structure were subtle.

It appears that Arctic headwater streams may be resilient and regain considerable functionality as local disturbance features begin to repair, particularly in the case of smaller features such as gulley thermokarst disturbance that experience stabilization by re-vegetation (Jorgenson et al., 2006). While the acute impacts of slumping are obvious and notable, it is the chronic impacts of long-term, elevated nutrient and sediment loading that are of greater interest. There is growing evidence that subtle differences in sediment and nutrient delivery to Arctic headwater streams can still be apparent many years after disturbance, and that thermokarst slumping may significantly affect primary producer biomass, benthic organic nutrients, benthic invertebrate community structure and key ecosystem functions such as whole-stream metabolism and nutrient update. Averaged over thaw-impacted landscapes as a whole, these effects may often be subtle (e.g. Alaska, Larouche et al., 2015). However, it is less clear how long-term nutrient and sediment loading will change in thaw-impacted stream systems (Frey and McClelland, 2009; Lewis et al., 2012; Lafrenière and Lamoureux, 2013; Malone et al., 2013).

\subsection{Export to ocean}

Permafrost degradation can lead to clear changes in the biogeochemical flux of constituents from land to water (see Sect. 2.2). Beyond the immediate site of impact, however, this constituent flux can be expected to have effects that range well into downstream environments. In many cases, changes on land can have clear impacts on coastal ocean processes, as has been shown within the estuarine zones of many large, southern rivers (Bianchi and Allison, 2009). In permafrostimpacted systems, understanding how changes in constituent flux at the terrestrial-aquatic interface will translate to changing export to the Arctic Ocean is still a challenging task. In this section, we describe the potential effects of permafrost thaw on land to ocean constituent flux, highlighting some major knowledge gaps in our current understanding of this process.

Scaling changes that are being observed at the small catchment scale to changes in ocean-bound transport requires an understanding of the rates of deposition, uptake, and de- composition of various thaw-released constituents, both in absolute terms and relative to their non-permafrost derived counterparts. These rates will vary considerably among constituent types. For example, nutrients released as a result of permafrost thaw may be taken up rapidly following release to aquatic environments (Alaska, Bowden et al., 2008), while major ions released following the exposure of mineral soils are largely conservative, and can be detected far downstream (NW Canada, Kokelj et al., 2013 and Malone et al., 2013). Similarly, in some regions, sediment pulses associated with thermokarst disturbances decline markedly with movement downstream (Alaska, Bowden et al., 2008), while in others, thaw-associated sediment signatures are elevated across broad, catchment-wide scales (NW Canada, Kokelj et al., 2013). The signature of permafrost thaw-origin sediments and particulate organics has also been detected at the mouths of several large Arctic rivers (Guo et al., 2007; Gustafsson et al., 2011), and in increasing concentrations in some Arctic coastal sediments (Feng et al., 2013).

Where direct observational evidence does exist to indicate changing biogeochemical flux at the mouths of Arctic rivers, it appears that some constituents are changing relatively synchronously across Arctic regions, while others may show significant regional differences in their trends. For example, flow-weighted bicarbonate fluxes appear to be increasing modestly in some Arctic regions, such as at the mouth of the Yukon River (Striegl et al., 2005). This trend is further corroborated by studies examining variation in riverine bicarbonate flux across Arctic watersheds with differing permafrost coverage (Tank et al., 2012a, c; Pokrovsky et al., 2015). In contrast, the downstream transport of DOC to coastal areas appears to be increasing in some, but decreasing in other, regions, based both on direct river-mouth measurements over time and sub-watershed comparisons across permafrost gradients (Kawahigashi et al., 2004; Striegl et al., 2005; Tank et al., 2012a). Furthermore, DOC originating in old permafrost may be preferentially degraded within stream networks, and thus may not be detectable at the river mouth (Yedoma-rich eastern Siberia; Spencer et al., 2015). It therefore remains difficult to attribute the few documented changes at the mouths of Arctic rivers to either up-catchment permafrost degradation or, for example, to the more widespread effects of changing temperature and precipitation patterns. For example, fluxes of DOC will be affected by changes in the composition and overall production and decomposition of vegetation (e.g. across northern regions, Laudon et al., 2012), in addition to the exposure of organic soils via permafrost thaw. Similarly, fluxes of bicarbonate will be affected not only by the thaw-mediated exposure of deeper mineral soils, but also by increases in root respiration that affect weathering rates (Beaulieu et al., 2012). For many constituents, changes in the seasonality of precipitation may also affect constituent flux and concentration (northern Canada, Spence et al., 2011). Research to explore how permafrost thaw affects aquatic biogeochemistry across nested 
spatial scales, and to further elucidate the mechanisms of changing chemistry at scales where direct, mechanistic, observations are possible, will greatly aid our ability to understand how up-catchment permafrost degradation affects biogeochemical flux to the coastal ocean.

The effect of changing riverine fluxes on coastal ocean processes cannot be considered without also considering thaw-induced changes in coastal erosion. Rates of coastal erosion vary by region, in part because of regional differences in ground ice content and bluff height (Lantuit et al., 2013). Overall, however, the impact of coastal erosion on biogeochemical flux to the ocean appears to be significant. Estimates of carbon release by coastal erosion vary significantly, and range between $5-14 \mathrm{Tg} \mathrm{OC}$ year $^{-1}$ for the entire Arctic combined (Rachold et al., 2004; Jorgenson and Brown, 2005; Vasiliev et al., 2005; Couture, 2010; Vonk et al., 2012b) with highest delivery rates in the Laptev and East Siberian seas (Vonk et al., 2012b). This value is nearly a third of the combined, circum-Arctic, estimated delivery of DOC (34 Tg; Holmes et al., 2012) and POC (6 Tg; McGuire et al., 2009) via rivers each year. Rates of coastal erosion, however, appear to be increasing both in the Russian and the Alaskan Arctic (Jones et al., 2009; Günther et al., 2013) which is due to decreasing sea ice content, allowing for higher storm intensity and wave fetch, along with increasing summertime sea surface temperature and a rising sea (IPCC, 2013).

Documented changes in riverine biogeochemistry and coastal erosion rates may in turn have a significant effect on carbon and nutrient cycles in the near-shore ocean. Where the delivery of DOC and POC increase, the attenuation of light will reduce photosynthetic uptake of $\mathrm{CO}_{2}$ (NW Canada, Retamal et al., 2008). Concomittantly, increases in both bacterial production, and the decomposition of this organic matter to $\mathrm{CO}_{2}$ may occur. On the east Siberian Shelf, for example, large zones of $\mathrm{CO}_{2}$ outgassing have been shown to occur alongside plumes of DOC that have a clear terrestrial isotopic signature (Anderson et al., 2009a). In addition, increases in light caused by sea ice retreat could also increase photochemical degradation of riverine DOM to $\mathrm{CO}_{2}$ (e.g. Tank et al., 2012b). If changing delivery of organic matter does affect coastal $\mathrm{CO}_{2}$ saturation, this could combine with changes in bicarbonate flux to have a significant impact on nearshore aragonite saturation, compounding the effects of temperature and sea ice melt on ocean acidification in the Arctic (Steinacher et al., 2009; Yamamoto-Kawai et al., 2009). In much of the Russian Arctic, organic carbon transport from land to ocean is already high (Holmes et al., 2012; Vonk et al., 2012b) when compared to the North American Arctic, and rivers are relatively bicarbonate-poor (Tank et al., 2012c). Thus, increasing delivery of organics to coastal zones, and the resultant $\mathrm{CO}_{2}$ production, could further reduce aragonite saturation in a region where the near-shore region is already poorly buffered (Anderson et al., 2011; Tank et al., 2012c). For these, and other constituents such as nutrients, we still have much to learn about how fluxes to the coastal ocean are changing, and how this change may affect nearshore biogeochemical function (Tank et al., 2012b; Le Fouest et al., 2013; Letscher et al., 2013). Understanding the effect of these changing fluxes in general, and the specific importance of permafrost thaw for changing biogeochemistry in the coastal Arctic, remains a clear priority for future research.

\subsection{Broad-scale climatic effects}

In addition to the numerous climate-related effects described above, thermokarst can be expected to have effects on climate that range beyond those that are directly related to aquatic processes. For example, thermokarst-enabled increases in inundated landscape area can be followed by loss of tree cover in the area surrounding thaw depressions, and a shift towards sedge-dominated fen vegetation (e.g. Jorgenson et al., 2001). The resulting change in albedo could subsequently affect regional radiative forcing, in a direction which will depend upon the manner in which vegetation changes affect snow cover (Notaro and Liu, 2007), and the relative change in cover of peat, forest, and water, because of the differences in albedo between these land cover types (e.g. Lohila et al., 2010). Additionally, energy partitioning into latent and sensible heat fluxes may be altered significantly upon thaw, as lake surfaces would be increasingly more important in certain regions, creating a distinct microclimate with high evapotranspiration and low sensible heat flux (e.g. Rouse et al., 2005). Lake energy balance varies widely with depth (e.g. Eaton et al., 2001), adding importance to the temporal changes in thermokarst lake sizes. Finally, thermokarstenabled changes in the emission of biogenic volatile organic compounds (BVOCs) through landscape shifts could also affect regional climate, because secondary aerosols originating from BVOCs facilitate cloud formation (e.g. Ehn et al., 2014). Taken as a whole, permafrost thaw and the occurrence of thermokarst will produce diverse and contra-directional climatic effects at different landscape, regional, and global scales. An approach that considers these multiple effects is therefore needed to understand how thermokarst affects regional and global climates.

\section{Summary and future research needs}

\subsection{Summary}

Ground-ice content, topography, and soil type are the main drivers for both types of permafrost thaw (press and pulse) and associated release of constituents into aquatic systems. (i) When thaw is manifested as a pulse disturbance, this leads to thermokarst lakes (lowland terrain) or slumping (hillslope terrain). For both features, the soil type of the pulsed material generally determines the release and effect of constituents; a pulse of OC-rich soils will colour thermokarst lakes (affecting stratification etc.), will cause low transparency (high turbidity) in aquatic ecosystems after thaw, and will lead to 
increasing OC export. A pulse of mineral-rich soils, however, might lead to clearer thermokarst lakes and decreasing OC in the water column, due to sorption of matter to mineral surfaces. (ii) When thaw is manifested as a press disturbance, this generally leads to longer flow paths and increasing residence time in soils. Here, the soil type of the thawed material generally determines the release and effect of constituents; thaw of OC-rich soils will lead to higher OC export whereas thaw of mineral-rich soils will lead to lower OC export.

The fate of released constituents and their effect on climate depends on the propensity of these constituents for degradation vs. burial, which is determined by environmental parameters as well as intrinsic properties. Also, it is important to distinguish between thaw-mobilization of old permafrost OC vs. contemporary OC, when considering the climatic effect potential. The degradability of released OC, representing the most direct carbon-climate "linkage", can be divided into a dissolved and a particulate fraction; the biodegradability of DOC is determined by source, chemical character, nutrient availability, temperature, and prior microbial and photochemical processing. Furthermore, DOC is generally more degradable when flushed from continuous permafrost regions, surface litter, active layer soils, and yedoma, but less degradable when flushed from deeper mineral soil layers. Photodegradation of DOC is relatively high in thawimpacted systems that are shallow, rich in light-absorbing DOM, or that undergo short-term (days to weeks) stratification events. Photodegradation can however be hampered by slumping of OC-rich soils (decreasing transparency) or slumping of mineral-rich soils (adsorbing CDOM). Our understanding of degradation of POC and the factors influencing it is still remarkably poor. Burial of $\mathrm{OC}$ is generally lower than total $\mathrm{OC}$ remineralization to $\mathrm{CO}_{2}$ and $\mathrm{CH}_{4}$, particularly in large and shallow lakes, but can be higher in small and deep lakes, thermokarst-yedoma lakes, and on the coastal shelf.

There are few studies on the effects of permafrost degradation on the ecology and food web structure of aquatic ecosystems. Thus, we can only speculate about future ecological conditions based on our current understanding of the function of high latitude systems and the effects of permafrost degradation on the physics and chemistry of impacted systems. The impact of permafrost thaw on food webs and ecosystem functioning appear likely to be driven by changes in the inputs of nutrients, DOM, and sediments. Primary production is stimulated by nutrient input but can be hindered by light suppression following increasing input of CDOM or OC-rich sediments, particularly when DOM concentrations are great enough that the positive effect of increasing organic nutrients is overwhelmed by the negative effect of decreasing light penetration (Seekell et al., 2015). Benthic communities can be destabilized by high sediment loading but may thrive when slumping of mineral-rich sediment leads to increasing water clarity. Overall, food web changes may lead to shifts in (i) OC resources supporting higher consumers, and (ii) the net heterotrophy of systems. Increasing terrestrial DOM input may be transferred to zooplankton and zoobenthos via increased heterotrophic bacterial production. On the other hand, in response to elevated turbidity levels, production, and respiration may decrease.

\subsection{Gaps in understanding, and future needs for research}

Aquatic ecosystems are widely recognized as locations of active processing and burial of the organic matter they receive (Cole et al., 2007; Battin et al., 2009), and, lately, also receive more attention in climate-carbon interactions in the Arctic (e.g. Sobek et al., 2003; Feng et al., 2013; Vonk and Gustafsson, 2013; Olefeldt and Roulet, 2014). However, in this review we have also identified numerous gaps in our knowledge of the diverse effects of permafrost thaw on aquatic ecosystems and the consequential effects on climate. We therefore make the following recommendations for future research directions, where we make the division into general directions, directions specific to streams and rivers, directions specific to thermokarst lakes, and the use of specific techniques.

\subsubsection{General future research directions}

\section{Fluxes and degradation of particulate $\mathrm{OC}$ from thawing permafrost}

Permafrost thaw, particularly when manifested as a pulse disturbance, can deliver substantial POC inputs to aquatic systems by exposing and rapidly thawing deep permafrost deposits. However, studies focusing on $\mathrm{OC}$ fluxes from thawing permafrost have to date mostly focused on DOC. Whereas DOC from collapsing permafrost is among the most biodegradable reported in natural systems (Vonk et al., 2013; Abbott et al., 2014; Spencer et al., 2015), the biodegradability of POC, released in far larger quantities, has never been properly assessed.

\section{The relative mobilization and degradability of old vs. contemporary carbon}

As thawing permafrost increases shoreline contact between lake water and soils, and increases direct slumping into lake and stream systems, the carbon that is introduced to aquatic systems will be from both shallow, contemporary, soil layers and from older, permafrost soils. Although permafrost DOC derived from yedoma appears to be highly degradable (see Sect. 3.1), there is also evidence that some thermokarst lakes emit modern carbon (see Sect. 4.1.2). Understanding the relative susceptibility of OC pools with permafrost-origin vs. contemporary-origin to bio- and photodegradation, and the relative mobilization of these two pools as a result of permafrost thaw across various regions and aquatic ecosystems, will help our ability to quantify the effect of carbon mobiliza- 
tion on climate across thaw-impacted systems. The priming effects generated by, for example, light and photosynthetic exudates on the consumption of old OC also needs to be further explored.

\section{Influence of permafrost thaw on fluxes to coastal ocean}

Our understanding of the effect of changing constituent fluxes following permafrost thaw on the optical characteristics, primary production, and biogeochemistry of coastal Arctic systems is still limited and remains a clear priority for future research.

\section{Resiliency of stream ecosystems to direct thermokarst impacts}

Very few studies have reported on the intensity or the duration of thermokarst impacts on the structure of biological communities or the function of key ecological processes (e.g. photosynthesis, respiration, and nutrient uptake) in Arctic streams (Calhoun, 2012; Larouche et al., 2015). It is impossible, therefore, to do more than speculate about how the ecosystem services provided by Arctic streams and rivers are changing in response to this regional impact of climate change.

\section{Trophic structure and food web processes}

The effect of permafrost thaw on aquatic autotrophic and heterotrophic communities, and their interaction, remains poorly studied. For example, resource use and growth by consumers in thermokarst lakes has not been quantified to date. Long-term effects of nutrient and sediment loading in thaw-impacted stream systems are still understudied, but are vital for effects on and shifts in receiving food webs.

\section{Microbial diversity and processes}

Microbial diversity studies have only recently begun, and there are many gaps in understanding. For example, the diversity and roles of viruses, likely the biologically most abundant particles in thaw waters, have not received attention to date. The composition of winter microbial communities in ice-covered thermokarst lakes and ponds is at present unknown, and only minimally studied in rivers (Crump et al., 2009) and the microbial processes operating under the ice have been little explored. These deserve special attention, given the long duration of ice cover in northern lakes, and the evidence of prolonged anoxia in these waters that favour anaerobic processes such as methanogenesis. The spring period of ice melt and partial mixing, and the prolonged period of mixing in autumn, may be important for gas exchange as well as key aerobic microbial processes such as methanotrophy, and these transition periods also require closer study.

\section{Improved assessment of underwater UV irradiance}

To specifically understand photodegradation of both old and contemporary DOM in thaw waters (see also bullet above), we further recommend work to (i) quantify UV spectral irradiance in thaw-impacted water columns, (ii) understand the residence time of DOM in the UV-exposed portion of the water column and its variability with changing mixing regimes, and (iii) identify the factors that control vertical losses of DOM and the lability of permafrost DOM to photodegradation.

\section{Inclusion and prioritization in models}

The export of $\mathrm{OC}$ and other constituents from Arctic aquatic systems remains poorly represented in ecosystem, landscape, and permafrost models. Generally, linkages between permafrost thaw and changes in surface hydrology (i.e. whether the Arctic landscape becomes wetter or drier after permafrost thaw), are poorly understood (Schuur et al., 2015). In the terrestrial ecosystem model (TEM) presented in McGuire et al. (2010), a riverine DOC export component is included which stems from simulating production and export of DOC from land. However, processing within rivers is not accounted for, which would ideally be needed to couple observed DOC data to input of DOC from soils. In addition, there are many other components that are currently not included in global or landscape-scale models, such as the release of DOC from pulse disturbances, the release and transport of POC from permafrost thaw (by pulse and press disturbances), or the release and transport of OC into thermokarst systems. Non-OC constituents (nutrients, sediment) are even more poorly represented in these models. Improving aquatic constituent fluxes, processing and transport should be a key prioritization in future model development.

\subsubsection{Research directions specific to streams and rivers}

\section{Watersheds of small and intermediate size}

Research to date has been somewhat skewed towards large rivers basins and estuaries; small watersheds and headwater streams where processes and change are easier to elucidate remain under-studied, meaning that it is often difficult to link measurements to clear source areas or processes.

\section{Sediment erosion vs. delivery to streams}

Stream-bank erosion effectively delivers $100 \%$ of eroded sediments to streams. But TEFs that form at some distance from streams may deliver far less sediment mass, $\mathrm{C}, \mathrm{N}$, and $\mathrm{P}$ to streams. To scale the effects of hillslope thermokarst to aquatic systems at broad spatial scales, we must better quantify how the position of various TEF features in the landscape moderates their effect on aquatic ecosystems. 


\section{Influences of hyporheic processes}

It is well known that the hyporheic zone (region below and alongside the stream) contributes substantially to nutrient and carbon processing in temperate and tropical streams (e.g. Boulton et al., 1998). Recent research has shown that despite the presence of permafrost, the hyporheic zone is equally important to the ecological functions of Arctic streams (e.g. Zarnetske et al., 2008). However, we do not know how thermokarst impacts will affect hyporheic processes or vice versa (Edwardson et al., 2003).

\subsubsection{Research directions specific to thermokarst lakes}

\section{Thermokarst lake processes in non-yedoma systems}

The emission and burial of thaw-released OC in yedoma thermokarst lakes has been a relatively large focus of research attention (e.g. Walter Anthony et al., 2007, 2014; Sepulveda-Jauregui et al., 2015), but the fate of thawreleased OC in thermokarst lakes in non-yedoma regions is still understudied. Considering that the yedoma region holds 210-456 Pg C and the total permafrost region holds 1330$1580 \mathrm{Pg} \mathrm{C}$ (Schuur et al., 2015), this makes non-yedoma regions holding $66-87 \%$ of the total permafrost $\mathrm{C}$ important to consider, particularly where non-yedoma regions are also lake-rich.

\section{Physical and hydrological dynamics of thermokarst lakes}

Current gaps in our understanding of the physical and hydrological dynamics of thermokarst lakes include the quantification of sediment heat transfer, penetration of solar radiation through ice cover, modelling of diffusive GHG exchange in small lakes, wave and energy dynamics associated with floating ice, and the extent of groundwater flow (Kirillin et al., 2012). Furthermore, material transport caused by advective water transfer between shallow zones to bottom waters such as found in MacIntyre and Melack (1995) in other systems has not been addressed in thaw waters.

\section{Hydrodynamic effects of high $\mathrm{CH}_{4}$ and $\mathrm{CO}_{2}$ concentrations}

Gradients in gas concentrations (particularly during icecovered periods) can cause density differences in the water column that can modify stratification such as suggested by Deshpande et al. (2015) but these effects have been little studied to date. Also, the effects on stratification by gas bubble trains associated with ebullition from sediments (Walter et al., 2006) have received little attention.

\section{Role of $\mathrm{CH}_{4}$ oxidation in thermokarst systems}

The emission of $\mathrm{CH}_{4}$ from aquatic ecosystems is significantly offset by microbial oxidation of $\mathrm{CH}_{4}$ (Trotsenko and Murrell, 2008). For example, in northern lakes, up to $88 \%$ of $\mathrm{CH}_{4}$ produced in sediments is oxidized by microbes (e.g. Bastviken et al., 2008) and abundant methanotrophs have been observed in thermokarst lakes. Oxidation of $\mathrm{CH}_{4}$ has recently been detected through laboratory incubation studies of thermokarst lakes in the boreal and tundra zones of Alaska (Martinez-Cruz et al., 2015); however, numerous questions remain to be answered with respect to (i) the extent to which $\mathrm{CH}_{4}$ oxidation offsets whole-lake emissions in thermokarstlake systems, (ii) which $\mathrm{CH}_{4}$-carbon pools are subject to oxidation (contemporary vs. old carbon), (iii) microbial community dynamics, and (iv) biogeochemical and ecological controls over $\mathrm{CH}_{4}$ oxidation among different thermokarst lake types.

\section{Lake carbon burial}

Our knowledge of the relative role of burial vs. processing in northern lakes remains poor. Tranvik et al. (2009) project that carbon burial in polar lakes will decrease whereas carbon burial in boreal lakes will increase. This review, however, points out that other factors such as permafrost type (yedoma vs. non-yedoma; Walter Anthony et al., 2014) or lake shape (small and deep vs. large and shallow; Ferland et al., 2012) strongly affect burial efficiencies and may overrule the distinction between boreal and polar regions. More research is needed to shed light on these processes.

\subsubsection{The use of specific techniques in future research}

\section{Usage of high-resolution automated loggers in thermokarst lakes}

Many thermokarst lakes undergo rapidly cycling stratification events (i.e. diurnal or several day) that are hard to capture with sparse measurements. The increased use of high resolution, automated temperature and $\mathrm{O}_{2}$ loggers is likely to yield new insights into short term (single to several day) stratification and mixing dynamics, even in those lakes currently considered to be well mixed in summer.

\section{Remote sensing}

We recommend increasing usage of high-resolution satellite remote sensing to assess (i) local landscape conditions that affect thermokarst formation, (ii) the changing areal coverage of thermokarst lakes and ponds in both discontinuous and continuous permafrost regions, as well as (iii) changing DOC lake concentrations (e.g. Watanabe et al., 2011) derived from changing lake surface colour as a result of permafrost thaw. 


\section{Radiocarbon dating}

The Arctic aquatic system should provide an early and sensitive signal of change in the cycling of OC in the terrestrial environment. The development of new direct methods to date aquatic dissolved $\mathrm{CO}_{2}$ (Billett et al., 2012; Garnett et al., 2012) has significantly increased our capacity to measure the source and age of $\mathrm{CO}_{2}$ released from Arctic landscapes; these along with existing dating tools for POC, DOC, and $\mathrm{CH}_{4}$, provide researchers with a strong methodological basis to quantify and detect the release of aged $\mathrm{C}$ into the aquatic environment. This will allow us to detect change or rates of change in areas of the Arctic undergoing differential rates of climate warming and address the key issue of whether "old" carbon (fixed $100 \mathrm{~s}$ or $1000 \mathrm{~s}$ of year BP) is being released directly or indirectly into the atmosphere.

\section{Eddy correlation flux measurements on thermokarst lakes}

Given its general applicability for studying lake-atmosphere exchanges of carbon (e.g. Vesala et al., 2012), we recommend increasing the application of eddy covariance on thermokarst lakes. We suggest that particular attention be paid to do the following: (i) eddy flux footprint analysis because the flux footprint often consists of a mixture of terrestrial and aquatic fluxes (Wille et al., 2008), it is important to use an appropriate footprint model (Vesala et al., 2008) supplemented with localized flux measurements (Sachs et al., 2010; Pelletier et al., 2014); (ii) usage of recently developed, low-maintenance instrumentation, such as robust, low power, open-path and enclosed-path gas analysers for $\mathrm{CO}_{2}$ and $\mathrm{CH}_{4}$ (Burba et al., 2012); (iii) the development of harmonized data processing protocols, as past efforts to compile data sets from large, terrestrial eddy covariance networks, such as FLUXNET (Baldocchi et al., 2001) have shown the importance of consistent data processing protocols to ensure comparability between sites. Processing protocols should be revised for application over lakes due to significant differences in surface processes of aquatic and terrestrial ecosystems (e.g. Vesala et al., 2012). Given the wide range of thermokarst lake sizes and types, a network of several flux towers has a great potential to better understand lakeatmosphere interactions of these ecosystems.

Acknowledgements. We thank all participants for their input and discussions at the THAW 2014 Workshop (www.cen.ulaval.ca/thaw2014/), held at the Centre d'études nordiques (CEN), Université Laval, Québec City, Canada and partially funded by the International Arctic Science Committee (IASC), the Climate and Cryosphere program (CliC), and the Natural Sciences and Engineering Research Council of Canada (NSERC) Discovery Frontiers project "Arctic Development and Adaptation to Permafrost in Transition" (ADAPT). We also acknowledge funding support from ADAPT towards the publication of this article, and support to individual authors from ArcticNet, the
Canada Research Chair program, NSERC, FRQNT, the Campus Alberta Innovates Program, the PAGE21, and DEFROST projects, Fonds de recherche du Québec (Nature et Technologies), Doctoral School in Atmospheric Sciences (University of Helsinki, Finland), the Fundação para a Ciência e Tecnologia (Portugal; project UID/QUI/00100/2013), the US-National Science Foundation (grant numbers ARC-0806394, ARC-1304823, DEB/LTER-1026843, CAREER-1255060, OPP-1023270, OPP-1107892), and the Netherlands Organization for Scientific Research (grant number 863.12.004). Finally, we would like to thank Charlene Nielsen (University of Alberta) for creating Fig. 1.

Edited by: V. Brovkin

\section{References}

Abbott, M. B. and Stafford, T. W.: Radiocarbon geochemistry of modern and ancient Arctic lake systems, Baffin Island, Canada, Quaternary Res., 45, 300-311, 1996.

Abbott, B. W., Larouche, J. R., Jones Jr., J. B., Bowden, W. B., and Balser, A. W.: Elevated dissolved organic carbon biodegradability from thawing and collapsing permafrost, J. Geophys. Res.Biogeo., 119, 2049-2063, 2014.

Abbott, B. W., Jones, J. B., Godsey, S. E., Larouche, J. R., and Bowden, W. B.: Patterns and persistence of hydrologic carbon and nutrient export from collapsing upland permafrost, Biogeosciences, 12, 3725-3740, doi:10.5194/bg-12-3725-2015, 2015.

Abnizova, A., Siemens, J., Langer, M., and Boike, J.: Small ponds with major impact: the relevance of ponds and lakes in permafrost landscapes to carbon dioxide emissions, Global Biogeochem. Cy., 26, GB2041, doi:10.1029/2011GB004237, 2012.

Abnizova, A., Young, K. L., and Lafrenière, M. J.: Pond hydrology and dissolved carbon dynamics at Polar Bear Pass wetland, Bathurst Island, Nunavut, Canada, Ecohydroly, 7, 73-90, 2014.

Aiken, G. R., Spencer, R. G. M., Streigl, R. G., Schuster, P. F., and Raymond, P. A.: Influences of glacier melt and permafrost thaw on the age of dissolved organic carbon in the Yukon River basin, Global Biogeochem. Cy., 28, 525-537, doi:10.1002/2013GB004764, 2014.

Åkerman, H. J. and Johansson, M.: Thawing permafrost and thicker active layers in sub-arctic Sweden, Permafrost Periglac., 19, 279-292, 2008.

Amon, R. M. W., Rinehart, A. J., Duan, S., Louchouarn, P., Prokushin, A., Guggenberger, G., Bauch, D., Stedmon, C., Raymond, P. A., Holmes, R. M., McClelland, J. W., Peterson, B. J., Walker, S. A., and Zhulidov, A. V.: Dissolved organic matter sources in large Arctic rivers, Geochim. Cosmochim. Ac., 94, 217-237, 2012.

Anderson, L. G., Jutterstrom, S., Hjalmarsson, S., Wahlstrom, I., and Semiletov, I. P.: Out-gassing of $\mathrm{CO}_{2}$ from Siberian Shelf seas by terrestrial organic matter decomposition, Geophys. Res. Lett., 36, L20601, doi:10.1029/2009GL040046, 2009a.

Anderson, N. J., d'Andrea, W., and Fritz, S. C.: Holocene carbon burial by lakes in SW Greenland, Glob. Change Biol., 15, 25902598, 2009b.

Anderson, L. G., Björk, G., Jutterström, S., Pipko, I., Shakhova, N., Semiletov, I., and Wåhlström, I.: East Siberian Sea, an Arctic 
region of very high biogeochemical activity, Biogeosciences, 8 , 1745-1754, doi:10.5194/bg-8-1745-2011, 2011.

Armitage, J. M. and Wania, F.: Exploring the potential influence of climate change and particulate organic carbon scenarios on the fate of neutral organic contaminants in the Arctic environment., Environ. Sci. Process. Impacts, 15, 2263-2272, 2013.

Arp, C. D., Jones, B. M., Urban, F. E., and Grosse, G.: Hydrogeomorphic processes of thermokarst lakes with grounded-ice and floating-ice regimes on the Arctic coastal plain, Alaska, Hydrol. Process., 25, 2422-2438, 2011.

Ask, J., Karlsson, J., Persson, L., Ask, P., Bystrom, P., and Jansson, M.: Terrestrial organic matter and light penetration: Effects on bacterial and primary production in lakes, Limnol. Oceanogr., 54, 2034-2040, 2009.

Ask, J., Karlsson, J., and Jansson, M.: Net ecosystem production in clear-water and brown-water lakes, Global Biogeochem. Cy., 26, GB1017, doi:10.1029/2010GB003951, 2012.

Audry, S., Pokrovsky, O. S., Shirokova, L. S., Kirpotin, S. N., and Dupré, B.: Organic matter mineralization and trace element post-depositional redistribution in Western Siberia thermokarst lake sediments, Biogeosciences, 8, 3341-3358, doi:10.5194/bg8-3341-2011, 2011.

Balcarczyk, K. L., Jones, J. B., Jaffe, R., and Maie, N.: Stream dissolved organic matter bioavailability and composition in watersheds underlain with discontinuous permafrost, Biogeochemistry, 94, 255-270, 2009.

Baldocchi, D., Falge, E., Gu, L., Olson, R., Hollinger, D., Running, S., Anthoni, P., Bernhofer, C., Davis, K., Evans, R., Fuentes, J., Goldstein, A., Katul, G., Law, B., Lee, X., Malhi, Y., Meyers, T., Munger, W., Oechel, W., Paw, K. T., Pilegaard, K., Schmid, H. P., Valentini, R., Verma, S., Vesala, T., Wilson, K., and Wofsy, S.: FLUXNET: A new tool to study the temporal and spatial variability of ecosystem-scale carbon dioxide, water vapor, and energy flux densities, B. Am. Meteorol. Soc., 82, 2415-2434, 2001.

Bartlett, K. B., Crill, P. M., Sass, R. L., Harriss, R. C., and Dise, N. B.: Methane emissions from tundra environments in the YukonKuskokwim delta, Alaska, J. Geophys. Res., 97, 16645-16660, 1992.

Bastviken, D., Cole, J. J., Pace, M. L., and Van de Bogert, M. C.: Fates of methane from different lake habitats: Connecting wholelake budgets and $\mathrm{CH}_{4}$ emissions, J. Geophys. Res.-Biogeo., 113, G02024, doi:10.1029/2007JG000608, 2008.

Bastviken, D., Tranvik, L. J., Downing, J. A., Crill, P. M., and Enrich-Prast, A.: Freshwater methane emissions offset the continental carbon sink, Science, 331, 6013, doi:10.1126/science.1196808, 2011.

Battin, T. J., Luyssaert, S., Kaplan, L. A., Aufdenkampe, A. K., Richter, A., and Tranvik, L. J.: The boundless carbon cycle, Nat. Geosci., 2, 598-600, 2009.

Bauch, H. A., Kassens, H., Naidina, O. D., Kunz-Pirrung, M., and Thiede, J.: Composition and flux of Holocene sediments on the Eastern Laptev Sea shelf, Arctic Siberia, Quaternary Res., 55, 344-351, 2001.

Beaulieu, E., Godderis, Y., Donnadieu, Y., Labat, D., and Roelandt, C.: High sensitivity of the continental-weathering carbon dioxide sink to future climate change, Nature Climate Change, 2, 346349, 2012

Bell, T. H., Yergeau, E., Maynard, C., Juck, D., Whyte, L. G., and Greer, C. W.: Predictable bacterial composition and hydrocarbon degradation in Arctic soils following diesel and nutrient disturbance, ISME J., 7, 1200-1210, 2013.

Bernhard, G., Dahlback, A., Fioletov, V., Heikkilä, A., Johnsen, B., Koskela, T., Lakkala, K., and Svendby, T.: High levels of ultraviolet radiation observed by ground-based instruments below the 2011 Arctic ozone hole, Atmos. Chem. Phys., 13, 10573-10590, doi:10.5194/acp-13-10573-2013, 2013.

Bianchi, T. A. and Allison, M. A.: Large-river delta-front estuaries as natural "recorders" of global environmental change, P. Natl. Acad. Sci. USA, 106, 8085-8092, 2009.

Billett, M. F., Garnett, M. G., Dinsmore, K. J., Dyson, K. E., Harvey, F., Thomson, A. M., Piirainen, S., and Kortelainen, P.: Age and source of different forms of carbon released from boreal peatland streams during spring snowmelt in E. Finland, Biogeochemistry, 111, 273-286, 2012.

Boereboom, T., Depoorter, M., Coppens, S., and Tison, J.-L.: Gas properties of winter lake ice in Northern Sweden: implication for carbon gas release, Biogeosciences, 9, 827-838, doi:10.5194/bg9-827-2012, 2012.

Boike, J., Georgi, C., Kirilin, G., Muster, S., Abramova, K., Fedorova, I., Chetverova, A., Grigoriev, M., Bornemann, N., and Langer, M.: Thermal processes of thermokarst lakes in the continuous permafrost zone of northern Siberia - observations and modeling (Lena River Delta, Siberia), Biogeosciences, 12, 59415965, doi:10.5194/bg-12-5941-2015, 2015.

Bouchard, F., Francus, P., Pienitz, R., and Laurion, I.: Sedimentology and geochemistry of thermokarst ponds in discontinuous permafrost, subarctic Québec, Canada, J. Geophys. Res., 116, G00M04, doi:10.1029/2011JG001675, 2011.

Bouchard, F., Pienitz, R., Ortiz, J. D., Francus, P., and Laurion, I.: Palaeolimnological conditions inferred from fossil diatom assemblages and derivative spectral properties of sediments in thermokarst ponds of subarctic Quebec, Canada, Boreas, 42, 575-595, doi:10.1111/bor.12000, 2012.

Bouchard, F., Turner, K. W., MacDonald, L. A., Deakin, C., White, H., Farquharson, N., Medeiros, A. S., Wolfe, B. B., Hall, R. I., Pienitz, R., and Edwards, T. W. D.: Vulnerability of shallow subarctic lakes to evaporate and desiccate when snowmelt runoff is low, Geophys. Res. Lett. 40, 6112-6117, 2013.

Bouchard, F., Laurion, I., Preskienis, V., Fortier, D., Xu, X., and Whiticar, M. J.: Modern to millennium-old greenhouse gases emitted from freshwater ecosystems of the eastern Canadian Arctic, Biogeosciences Discuss., 12, 11661-11705, doi:10.5194/bgd-12-11661-2015, 2015.

Boulton, A. J., Findlay, S., Marmonier, P., Stanley, E. H., and Valett, H. M.: The functional significance of the hyporheic zone in streams and rivers, Annu. Rev. Ecol. Syst., 29, 59-81, 1998.

Bowden, W. B., Gooseff, M. N., Balser, A., Green, A., Peterson, B. J., and Bradford, J.: Sediment and nutrient delivery from thermokarst features in the foothills of the North Slope, Alaska: Potential impacts on headwater stream ecosystems, J. Geophys. Res., 113, G02026, doi:10.1029/2007JG000470, 2008.

Bowden, W. B., Finlay, J. C., and Maloney, P. E.: Long-term effects of $\mathrm{PO}_{4}$ fertilization on the distribution of bryophytes in an arctic river, Freshwater Biol., 32, 445-454, 1994.

Bowling, L. C., Kane, D. L., Gieck, R. E., Hinzman, L. D., and Lettenmaier, D. P.: The role of surface storage in a low-gradient Arctic watershed, Water Resour. Res., 39, 1087, doi:10.1029/2002WR001466, 2003. 
Breton, J., Vallières, C., and Laurion, I.: Limnological properties of permafrost thaw ponds in northeastern Canada, Can. J. Fish. Aquat. Sci., 66, 1635-1648, 2009.

Brosius, L. S., Walter Anthony, K. M., Grosse, G., Chanton, J. P., Farquharson, L. M., Overduin, P. P., and Meyer, H.: Using the deuterium isotope composition of permafrost meltwater to constrain thermokarst lake contributions to atmospheric $\mathrm{CH}_{4}$ during the last deglaciation, J. Geophy. Res.-Biogeo., 117, G01022, doi:10.1029/2011JG001810, 2012.

Brown, J., Ferrians Jr., O. J., Heginbottom, J. A., and Melnikov, E. S.: Circumarctic Map of Permafrost and Ground-Ice Conditions, Report, National Snow and Ice Data Center, World Data Center for Glaciol Boulder, CO, 1998.

Bryksina, N. A., Polishuyk, V. Y., and Polihsuyk, Y. M.: Database of the thermokarst lakes of Western Siberia based on the satellite images and the possibilities of its practical use (in Russian), Sovremennye problemy distantsionnogo zondirovaniya Zemli iz kosmosa, 8, 175-181, 2011.

Burba, G., Schmidt, A., Scott, R. L., Nakai, T., Kathilankal, J., Fratini, G., Hanson, C., Law, B., McDermitt, D. K., Eckles, R., Furtaw, M., and Velgersdyk, M.: Calculating $\mathrm{CO}_{2}$ and $\mathrm{H}_{2} \mathrm{O}$ eddy covariance fluxes from an enclosed gas analyzer using an instantaneous mixing ratio, Glob. Change Biol., 18, 385-399, 2012.

Burn, C. R.: Lake-bottom thermal regime in thermokarst terrain near Mayo, Yukon Territory, Canada, Proceedings of the 8th International Conference on Permafrost, Zurich, Switzerland, 113118, 2003.

Buschmann, J., Canonica, S., Lindauer, U., Hug, S. J., and Sigg, L.: Photoirradiation of dissolved humic acid induces arsenic(III) oxidation, Environ. Sci. Technol., 39, 9541-9546, 2005.

Calhoun, J. P.: Permafrost degradation and river metabolism: downstream effects of retrogressive thaw slump sedimentation on ecosystem metabolism in the Selawik River, Alaska, Idaho State University, Pocatello, Idaho, USA, 95 pp., 2012.

Cappelletti, C.: Photosynthesis and respiration in an arctic tundra river: modification and application of the whole-stream metabolism method and the influence of physical, biological, and chemical variables, University of Vermont, Burlington, 2006.

Carlson, A. E. and Barnes, D. L.: Movement of trichloroethene in a discontinuous permafrost zone, J. Contam. Hydrol., 124, 1-13, 2011.

Chénard, C., Chan, A. M., Vincent, W. F., and Suttle, C. A.: Polar freshwater cyanophage S-EIV1 represents a new widespread evolutionary lineage of phages, ISME J., 9, 20462058, doi:10.1038/ismej.2015.24, 2015.

Chételat, J., Amyot, M., Arp, P., Blais, J. M., Depew, D., Emmerton, C. A., Evans, M., Gamberg, M., Gantner, N., Girard, C., Graydon, J., Kirk, J., Lean, D., Lehnherr, I., Muir, D., Nasr, M., Poulain, A. J., Power, M., Roach, P., Stern, G., Swanson, H., and van der Velden, S.: Mercury in freshwater ecosystems of the Canadian Arctic: Recent advances on its cycling and fate, Sci. Total Environ., 509-510, 41-66, 2014.

Cole, J. J., Prairie, Y. T., Caraco, N. F., McDowell, W. H., Tranvik, L. J., Striegl, R. G., Duarte, C. M., Kortelainen, P., Downing, J. A., Middelburg, J. J., and Melack, J.: Plumbing the global carbon cycle: Integrating inland waters into the terrestrial carbon budget, Ecosystems, 10, 171-184, 2007.

Comte, J., Monier, A., Crevecoeur, S., Lovejoy, C., and Vincent, W. F.: Bacterial biogeography of permafrost thaw lakes in the changing northern landscape, Ecography, 38, 1-10, doi:10.1111/ecog.01667, 2015.

Cory, R. M., McNeill, K., Cotner, J. P., Amado, A., Purcell, J. M., and Marshall, A. G.: Singlet oxygen in the coupled photochemical and biochemical oxidation of dissolved organic matter, Environ. Sci. Technol., 44, 3683-3689, 2010.

Cory, R. M., Crump, B. C., Dobkowski, J. A., and Kling, G. W.: Surface exposure to sunlight stimulates $\mathrm{CO}_{2}$ release from permafrost soil carbon in the Arctic, P. Natl. Acad. Sci. USA, 110, 3429-3434, 2013.

Cory, R. M., Ward, C. P., Crump, B. C., and Kling, G. W.: Sunlight controls water column processing of carbon in arctic fresh waters, Science, 345, 925-928, 2014.

Côté, M. M. and Burn, C. R.: The oriented lakes of Tuktoyaktuk Peninsula, Western Arctic Coast, Canada: a GIS-based analysis, Permafrost Periglac., 13, 61-70, 2002.

Couture, N.: Fluxes of soil organic carbon from eroding permafrost coasts, Canadian Beaufort Sea, PhD thesis, Department of Geography, McGill University, Montreal, 2010.

Craig, N., Jones, S. E., Weidel, B. C., and Solomon, C. T.: Habitat, not resource availability, limits consumer production in lake ecosystems, Limnol. Oceanogr., 60, 2079-2089, doi:10.1002/lno.10153, 2015.

Crawford, J. T., Striegl, R. G., Wickland, K. P., Dornblaser, M. M., and Stanley, E. H.: Emissions of carbon dioxide and methane from a headwater stream network of interior Alaska, J. Geophys. Res.-Biogeo., 118, 482-494, 2013.

Crevecoeur, S., Vincent, W. F., Comte, J., and Lovejoy, C.: Bacterial community structure across environmental gradients in permafrost thaw ponds: Methanotroph-rich ecosystems, Front. Microbiol., 6, 192, doi:10.3389/fmicb.2015.00192, 2015.

Crump, B. C., Peterson, B. J., Raymond, P. A., Amon, R. M. W., Rinehart, A., McClelland, J. W., and Holmes, R. M.: Circumpolar synchrony in big river bacterioplankton, P. Natl. Acad. Sci USA, 106, 21208-21212, 2009.

Crump, B. C., Amaral-Zettler, L. A., and Kling, G. W.: Microbial diversity in arctic freshwaters is structured by inoculation of microbes from soils, ISME J., 6, 1629-1639, 2012.

Curtosi, A., Pelletier, E., Vodopivez, C. L., and Mac Cormack, W. P.: Polycyclic aromatic hydrocarbons in soil and surface marine sediment near Jubany Station (Antarctica), Role of permafrost as a low-permeability barrier, Sci. Total Environ., 383, 193-204, 2007.

Deison, R., Smol, J. P., Kokelj, S. V, Pisaric, M. F. J., Kimpe, L. E., Poulain, A. J., Sanei, H., Thienpont, J. R., and Blais, J. M.: Spatial and temporal assessment of mercury and organic matter in thermokarst affected lakes of the Mackenzie Delta uplands, NT, Canada, Environ. Sci. Technol., 46, 8748-8755, 2012.

Denfeld, B. A., Frey, K. E., Sobczak, W. V., Mann, P. J., and Holmes, R. M.: Summer $\mathrm{CO}_{2}$ evasion from streams and rivers in the Kolyma River basin, north-east Siberia, Polar Res., 32, 19704, doi:10.3402/polar.v32i0.19704, 2013.

Deshpande, B., MacIntyre, S., Matveev, A., and Vincent, W. F.: Oxygen dynamics in permafrost thaw lakes: Anaerobic bioreactors in the Canadian subarctic, Limnol. Oceanogr., 60, 16561670, doi:10.1002/lno.10126, 2015.

Desyatkin, A. R., Takakai, F., Fedorov, P. P., Nikolaeva, M. C., Desyatkin, R. V., and Hatano, R.: $\mathrm{CH}_{4}$ emission from different 
stages of thermokarst formation in Central Yakutia, East Siberia, Soil Sci. Plant Nutr., 55, 558-570, 2009.

Dingman, S., Barry, R., Weller, G., Benson, C., LeDrew, E., and Goodwin, C.: Climate, snow cover, microclimate, and hydrology, in: An Arctic Ecosystem: the Coastal Tundra at Barrow, Alaska, edited by: Brown, J., Miller, P., Tieszen., L., and Bunnell, F., The Institute of Ecology, Stroudsburg, PA, 30-65, 1980.

Doğrul Selver, A., Talbot, H. M., Gustafsson, O., Boult, S., and van Dongen, B. E.: Soil organic matter transport along a sub-Arctic river-sea transect, Org. Geochem., 51, 63-72, 2012.

Doğrul Selver, A., Sparkes, R. B., Bischoff, J., Talbot, H. M., Gustafsson, O., Semiletov, I. P., Dudarev, O. V., Boult, S., and van Dongen, B. E.,: Distributions of bacterial and archaeal membrane lipids in surface sediments reflect differences in input and loss of terrestrial organic carbon along a cross-shelf Arctic transect, Org. Geochem., 83-84, 16-26, doi:10.1016/j.orggeochem.2015.01.005, 2015.

Dugan, H. A., Lamoureux, S. F., Lewis, T., and Lafrenière, M. J.: The impact of permafrost disturbances and sediment loading on the limnological characteristics of two High Arctic lakes, Permafrost Periglac., 23, 119-126, 2012.

Duguay, C. R., Pultz, T. J., Lafleur, P. M., and Drai, D.: RADARSAT backscatter characteristics of ice growing on shallow sub-Arctic lakes, Churchill, Manitoba, Canada, Hydrol. Process., 16, 1631$1644,2002$.

Dyke, L. D.: Contaminant migration through the permafrost active layer, Mackenzie Delta area, Northwest Territories, Canada, Polar Rec., 37, 215-228, 2001.

Eaton, A., Rouse, W., Lafleur, P., Marsh, P., and Blanken, D.: Surface energy balance of the western and central canadian subarctic: variations in the energy balance among five major terrain types, J. Climate, 14, 3692-3703, 2001.

Edwardson, K. J., Bowden, W. B., Dahm, C., and Morrice, J.: The hydraulic characteristics and geochemistry of hyporheic and parafluvial zones in Arctic tundra streams, north slope Alaska, Adv. Water Resour., 26, 907-923, doi:10.1016/S03091708(03)00078-2, 2003.

Emmerton, C. A., St. Louis, V. L., Lehnherr, I., Humphreys, E. R., Rydz, E., and Kosolofski, H. R.: The net exchange of methane with high Arctic landscapes during the summer growing season, Biogeosciences, 11, 3095-3106, doi:10.5194/bg-11-3095-2014, 2014.

Ehn, M., Thornton, J., Kleist, E., Sipilä, M., Junninen, H., Pullinen, I., Springer, M., Rubach, F., Tillmann, R., Lee, B., LopezHilfiker, F., Andres, S., Acir, I.-H. Rissanen, M., Jokinen, T., Schobesberger, S., Kangasluoma, J., Kontkanen, J., Nieminen, T., Kurtén, T., Nielsen, L., Jørgensen, S., Kjaergaard, H., Canagaratna, M., Dal Maso, M., Berndt, T., Petäjä, T., Wahner, A., Kerminen, V.-M., Kulmala, M., Worsnop, D., Wildt, J., and Mentel. T.: A large source of low-volatility secondary organic aerosol, Nature, 506, 476-479, 2014.

Erickson III, D. J., Sulzberger, B., Zepp, R. G., and Austin, A. T.: Effects of stratospheric ozone depletion, solar UV radiation, and climate change on biogeochemical cycling: interactions and feedbacks, Photochem. Photobio. Sci., 14, 127-148, 2015.

Eugster, W.: $\mathrm{CO}_{2}$ exchange between air and water in an Arctic Alaskan and midlatitude Swiss lake: Importance of convective mixing, J. Geophys. Res., 108, 4362, doi:10.1029/2002JD002653, 2003.
Eugster, W., DelSontro, T., and Sobek, S.: Eddy covariance flux measurements confirm extreme $\mathrm{CH}_{4}$ emissions from a Swiss hydropower reservoir and resolve their short-term variability, Biogeosciences, 8, 2815-2831, doi:10.5194/bg-8-2815-2011, 2011.

Feng, X. J., Vonk, J. E., van Dongen, B. E., Gustafsson, O., Semiletov, I. P., Dudarev, O. V., Wang, Z. H., Montlucon, D. B., Wacker, L., and Eglinton, T. I.: Differential mobilization of terrestrial carbon pools in Eurasian Arctic river basins, P. Natl. Acad. Sci. USA, 110, 14168-14173, 2013.

Ferland, M. E., del Giorgio, P. A., Teodoru, C. R., and Prairie, Y. T.: Long-term $\mathrm{C}$ accumulation and total $\mathrm{C}$ stocks in boreal lakes in northern Quebec, Global Biogeochem. Cy., 26, GB0E04, doi:10.1029/2011GB004241, 2012.

Ferland, M. E., Prairie, Y., Teodoru, C., and del Giorgio, P. A.: Linking organic carbon sedimentation, burial efficiency, and longterm accumulation in boreal lakes, J. Geophys. Res.-Biogeo., 119, 836-847, 2014.

Forsström, L., Rautio, M., Cusson, M., Sorvari, S., Albert, R.-L., Kumagai, M., and Korhola, A.: Dissolved organic matter concentration, optical parameters and attenuation of solar radiation in high-latitude lakes across three vegetation zones, Écoscience, 22, 17-31, 2015.

Frank-Fahle, B. A., Yergeau, E., Greer, C. W., Lantuit, H. and Wagner, D.: Microbial functional potential and community composition in permafrost-affected soils of the NW Canadian Arctic., PLoS ONE, 9, e84761, doi:10.1371/journal.pone.0084761, 2014.

Frey, K. E. and McClelland, J. W.: Impacts of permafrost degradation on arctic river biogeochemistry, Hydrol. Process., 23, 169$182,2009$.

Frey, K. E. and Smith, L. C.: Amplified carbon release from vast West Siberian peatlands by 2100 , Geophys. Res. Lett., 32, L09401, doi:10.1029/2004GL022025, 2005.

Frey, K. E., Siegel, D. I., and Smith, L. C.: Geochemistry of west Siberian streams and their potential response to permafrost degradation, Water Resour. Res., 43, W03406, doi:10.1029/2006WR004902, 2007.

Frey, K. E., Sobczak, W. V., Mann, P. J., and Holmes, R. M.: Optical properties and bioavailability of dissolved organic matter along a flow-path continuum from soil pore waters to the Kolyma River, Siberia, Biogeosciences Discuss., 12, 1232112347, doi:10.5194/bgd-12-12321-2015, 2015.

Fritz, M., Opel, T., Tanski, G., Herzschuh, U., Meyer, H., Eulenburg, A., and Lantuit, H.: Dissolved organic carbon (DOC) in Arctic ground ice, The Cryosphere, 9, 737-752, doi:10.5194/tc9-737-2015, 2015.

Gareis, J. A. L., Lesack, L. F. W., and Bothwell, M. L.: Attenuation of in situ UV radiation in Mackenzie Delta lakes with varying dissolved organic matter compositions, Water Resour. Res., 46, 1-14, 2010.

Garnett, M. H., Dinsmore, K. J., and Billett M. F.: Annual variability in the radiocarbon age and source of dissolved $\mathrm{CO}_{2}$ in a peatland stream, Sci. Total Environ., 427-428, 277-285, 2012.

Godin, E., Fortier, D., and Lévesque, E.: Nonlinear thermal and moisture dynamics of high Arctic wetland polygons following permafrost disturbance, Biogeosciences Discuss., 12, $11797-$ 11831, doi:10.5194/bgd-12-11797-2015, 2015. 
Golubyatnikov, L. L. and Kazantsev, V. S.: Contribution of tundra lakes in western Siberia to the atmospheric methane budget, Izv. Atmos. Ocean. Phys., 49, 395-403, 2013.

Grannas, A. M., Bogdal, C., Hageman, K. J., Halsall, C., Harner, T., Hung, H., Kallenborn, R., Klán, P., Klánová, J., Macdonald, R. W., Meyer, T., and Wania, F.: The role of the global cryosphere in the fate of organic contaminants, Atmos. Chem. Phys., 13, 32713305, doi:10.5194/acp-13-3271-2013, 2013.

Grasby, S. E., Rod Smith, I., Bell, T., and Forbes, D. L.: Cryogenic formation of brine and sedimentary mirabilite in submergent coastal lake basins, Canadian Arctic, Geochim. Cosmochim. Ac., 110, 13-28, 2013.

Greene, S., Walter Anthony, K. M., Archer, D., Sepulveda-Jauregui, A., and Martinez-Cruz, K.: Modeling the impediment of methane ebullition bubbles by seasonal lake ice, Biogeosciences, 11, 6791-6811, doi:10.5194/bg-11-6791-2014, 2014.

Grosse, G., Harden, J., Turetsky, M., McGuire, A. D., Camill, P., Tarnocai, C., Frolking, S., Schuur, E. A. G., Jorgenson, T., Marchenko, S., Romanovsky, V., Wickland, K. P., French, N., Waldrop, M., Bourgeau-Chavez, L., and Striegl, R. G.: Vulnerability of high-latitude soil organic carbon in North America to disturbance, J. Geophys. Res., 116, G00K06, doi:10.1029/2010JG001507, 2011.

Grosse, G., Jones, B., and Arp, C.: Thermokarst lakes, drainage, and drained basins, in: Treatise on Geomorphology, edited by: Shroder, J., Giardino, R., and Harbor, J., Academic Press, San Diego, USA, 325-353, 2013.

Günther, F., Overduin, P. P., Sandakov, A. V., Grosse, G., and Grigoriev, M. N.: Short- and long-term thermo-erosion of ice-rich permafrost coasts in the Laptev Sea region, Biogeosciences, 10, 4297-4318, doi:10.5194/bg-10-4297-2013, 2013.

Guo, L. D., Ping, C. L., and Macdonald, R. W.: Mobilization pathways of organic carbon from permafrost to arctic rivers in a changing climate, Geophys. Res. Lett., 34, L13603, doi:10.1029/2007GL030689, 2007.

Gustafsson, Ö., van Dongen, B. E., Vonk, J. E., Dudarev, O. V., and Semiletov, I. P.: Widespread release of old carbon across the Siberian Arctic echoed by its large rivers, Biogeosciences, 8, 1737-1743, doi:10.5194/bg-8-1737-2011, 2011.

Hamilton, P. B., Gajewski, K., Atkinson, D. E., and Lean, D. R. S.: Physical and chemical limnology of 204 lakes from the Canadian Arctic Archipelago, Hydrobiologia, 457, 133-148, 2001.

Hammerschmidt, C. R. and Fitzgerald, W. F.: Iron-mediated photochemical decomposition of methylmercury in an Arctic Alaskan lake, Environ. Sci. Technol., 44, 6138-6143, 2010.

Harms, T. K. and Jones Jr., J. B.: Thaw depth determines reaction and transport of inorganic nitrogen in valley bottom permafrost soils, Glob. Change Biol., 18, 2958-2968, 2012.

Hinkel, K. M., Frohn, R. C., Nelson, F. E., Eisner, W. R., and Beck, R. A.: Morphometric and spatial analysis of thaw lakes and drained thaw lake basins in the western Arctic Coastal Plain, Alaska, Permafrost Periglac., 16, 327-341, 2005.

Hinkel, K. M., Lenters, J. D., Sheng, Y., Lyons, E. A., Beck, R. A., Eisner, W. R., Maurer, E. F., Wang, J., and Potter, B. L.: Thermokarst lakes on the Arctic Coastal Plain of Alaska: Spatial and temporal variability in summer water temperature, Permafrost Periglac., 23, 207-217, 2012.
Hobbie, J. E.: Limnology of tundra ponds, Barrow, Alaska, US/IBP Synthesis Series 13, Dowden, Hutchinson \& Ross, Stroudsburg, Pennsylvania, 1980.

Holmes, R. M., McClelland, J. W., Raymond, P. A., Frazer, B. B., Peterson, B. J., and Stieglitz, M.: Lability of DOC transported by Alaskan rivers to the arctic ocean, Geophys. Res. Lett., 35, L03402, doi:10.1029/2007GL032837, 2008.

Holmes, R. M., McClelland, J. W., Peterson, B. J., Tank, S. E., Bulygina, E., Eglinton, T. I., Gordeev, V. V., Gurtovaya, T. Y., Raymond, P. A., Repeta, D. J., Staples, R., Striegl, R. G., Zhulidov, A. V., and Zimov, S. A.: Seasonal and annual fluxes of nutrients and organic matter from large rivers to the Arctic Ocean and surrounding seas, Estuar. Coast., 35, 369-382, 2012.

Hong, J., Xie, H., Guo, L., and Song, G.: Carbon monoxide photoproduction: implications for photoreactivity of arctic permafrostderived soil dissolved organic matter, Environ. Sci. Technol., 48, 9113-9121, 2014.

Hopkins, D. M.: Thaw lakes and thaw sinks in the Imuruk lake area, Seward Peninsula, Alaska, J. Geology, 57, 119-131, 1949.

Hynes, H. B. N.: The Ecology of Running Waters, Liverpool University Press, Liverpool, 555 pp., 1970.

IPCC: Climate Change 2013: Mitigation of Climate Change. Contribution of Working Group III to the Fifth Assessment Report of the Intergovernmental Panel on Climate Change, Cambridge University Press, Cambridge, United Kingdom and New York, NY, USA, 2013.

Jansson, J. K. and Tas, N.: The microbial ecology of permafrost, Nat. Rev. Microbiol., 12, 414-425, doi:10.1038/nrmicro3262, 2014.

Jansson, M., Persson, L., De Roos, A. M., Jones, R. I., and Tranvik, L. J.: Terrestrial carbon and intraspecific size-variation shape lake ecosystems, Trends Ecol. Evol., 22, 316-322, 2007.

Jones, B. M., Arp, C. D., Jorgenson, M. T., Hinkel, K. M., Schmutz, J. A., and Flint, P. L.: Increase in the rate and uniformity of coastline erosion in Arctic Alaska, Geophys. Res. Lett., 36, 35033503, 2009.

Jones, J. B., Petrone, K. C., Finlay, J. C., Hinzman, L. D., and Bolton, W. R.: Nitrogen loss from watersheds of interior Alaska underlain with discontinuous permafrost, Geophys. Res. Lett., 32, L02401, doi:10.1029/2004GL021734, 2005.

Jones, R. I.: Mixotrophy in planktonic protists: an overview, Freshwater Biol., 45, 219-226, 2000.

Jorgenson, M. T. and Brown, J.: Classification of the Alaskan Beaufort Sea Coast and estimation of carbon and sediment inputs from coastal erosion, Geo-Mar. Lett., 25, 69-80, 2005.

Jorgenson, M. T., Racine, C. H., Walters, J. C., and Osterkamp, T. E.: Permafrost degradation and ecological changes associated with a warming in central Alaska, Climatic Change, 48, 551-579, 2001.

Jorgenson, M. T., Shur, Y. L., and Pullman, E. R.: Abrupt increase in permafrost degradation in Arctic Alaska, Geophys. Res. Lett., 33, L02503, doi:10.1029/2005GL024960, 2006.

Judd, K., Crump, B., and Kling, G.: Bacterial responses in activity and community composition to photo-oxidation of dissolved organic matter from soil and surface waters, Aquat. Sci., 69, 96107, doi:10.1007/s00027-006-0908-4, 2007.

Kanevskiy, M., Shur, Y., Fortier, D., Jorgenson, M. T., and Stephani, E.: Cryostratigraphy of late Pleistocene syngenetic permafrost 
(yedoma) in northern Alaska, Itkillik River exposure, Quaternary Res., 75, 584-596, 2011.

Kankaala, P., Taipale, S., Grey, J., Sonninen, E., Arvola, L., and Jones, R. I.: Experimental delta ${ }^{13} \mathrm{C}$ evidence for a contribution of methane to pelagic food webs in lakes, Limnol. Oceanogr., 51, 2821-2827, 2006.

Karlsson, E. S., Charkin, A., Dudarev, O., Semiletov, I., Vonk, J. E., Sánchez-García, L., Andersson, A., and Gustafsson, Ö.: Carbon isotopes and lipid biomarker investigation of sources, transport and degradation of terrestrial organic matter in the Buor-Khaya Bay, SE Laptev Sea, Biogeosciences, 8, 1865-1879, doi:10.5194/bg-8-1865-2011, 2011.

Karlsson, J., Christensen, T. R., Crill, P., Forster, J., Hammarlund, D., Jackowicz-Korczynski, M., Kokfelt, U., Roehm, C., and Rosen, P.: Quantifying the relative importance of lake emissions in the carbon budget of a subarctic catchment, J. Geophys. Res.Biogeo., 115, G03006, doi:10.1029/2010JG001305, 2010.

Karlsson, J., Giesler, R., Persson, J., and Lundin, E.: High emission of carbon dioxide and methane during ice thaw in high latitude lakes: carbon emission from lakes in spring, Geophys. Res. Lett., 40, 1123-1127, 2013.

Karlsson, J. A.-K. Bergström, A.-K., Byström, P., Gudasz, C., Rodríguez, P., and Hein, C. L.: Terrestrial organic matter input suppresses biomass production in lake ecosystems, Ecology, 96, 2870-2876, doi:10.1890/15-0515.1, 2015.

Kasahara, T. and Hill, A. R.: Effects of riffle step restoration on hyporheic zone chemistry in N-rich lowland streams, Can. J. Fish. Aquat. Sci., 63, 120-133, 2006.

Kawahigashi, M., Kaiser, K., Kalbitz, K., Rodionov, A., and Guggenberger, G.: Dissolved organic matter in small streams along a gradient from discontinuous to continuous permafrost, Glob. Change Biol., 10, 1576-1586, 2004.

Keller, K., Blum, J. D., and Kling, G. W.: Stream geochemistry as an indicator of increasing permafrost thaw depth in an arctic watershed, Chem. Geol., 273, 76-81, 2010.

Kessler, M. A., Plug, L., and Walter Anthony, K. M.: Simulating the decadal to millennial scale dynamics of morphology and sequestered carbon mobilization of two thermokarst lakes in N. W. Alaska, J. Geophys. Res., 117, G00M06, doi:10.1029/2011JG001796, 2012.

Kirillin, G., Leppäranta, M., Terzhevik, A., Granin, N., Bernhardt, J., Engelhardt, C., Efremova, T., Golosov, S., Palshin, N., Sherstyankin, P., Zdorovennova, G., and Zdorovennov, R.: Physics of seasonally ice-covered lakes: a review, Aquat. Sci., 74, 659-682, 2012.

Kirpotin, S. N., Polishchuk, Y., and Bryksina, N.: Dynamics of the thermokarst lake areas in the continuous permafrost zone of Western Siberia under global warming conditions, Vestnik Tomskogo Gosudarstvennogo Universiteta, 311, 185-189, 2008 (in Russian).

Klaminder, J., Yoo, K., Rydberg, J., and Giesler, R.: An explorative study of mercury export from a thawing palsa mire, J. Geophys. Res., 113, 1-9, 2008.

Klaminder, J., Hammarlund, D., Kokfelt, U., Vonk, J. E., and Bigler, C.: Lead Contamination of Subarctic Lakes and its Response to Reduced Atmospheric Fallout: Can the Recovery Process Be Counteracted by the Ongoing Climate Change?, Environ. Sci. Technol., 44, 2335-2340, 2010.
Kling, G. W., Kipphut, G. W., and Miller, M. C.: Arctic lakes and streams as gas conduits to the atmosphere: Implications for tundra carbon budgets, Science, 251, 298-301, 1991.

Kling, G. W., Kipphut, G. W., and Miller, M. C.: The flux of $\mathrm{CO}_{2}$ and $\mathrm{CH}_{4}$ from lakes and rivers in arctic Alaska, Hydrobiologia, 240, 23-36, 1992.

Koch, J. C., Runkel, R. L., Striegl, R., and McKnight, D. M.: Hydrologic controls on the transport and cycling of carbon and nitrogen in a boreal catchment underlain by continuous permafrost, J. Geophys. Res.-Biogeo., 118, 698-712, doi:10.1002/jgrg.20058, 2013.

Koch, J. C., Kikuchi, C. P., Wickland, K. P., and Schuster, P.: Runoff sources and flow paths in a partially burned, upland boreal catchment underlain by permafrost, Water Resour. Res., 50, 81418158, doi:10.1002/2014WR015586, 2014.

Koehler, B., Landelius, T., Weyhenmeyer, G. A., Machida, N., and Tranvik, L. J.: Sunlight-induced carbon dioxide emissions from inland waters, Global Biogeochem. Cy., 28, 696-711, 2014.

Kokelj, S. V. and Jorgenson, M. T.: Advances in thermokarst research, Permafrost Periglac., 24, 108-119, 2013.

Kokelj, S. V., Jenkins, R. E., Milburn, D., Burn, C. R., and Snow, N.: The influence of thermokarst disturbance on the water quality of small upland lakes, Mackenzie Delta Region, Northwest Territories, Canada, Permafrost Periglac., 16, 343-353, 2005.

Kokelj, S. V., Zajdlik, B., and Thompson, M. S.: The impacts of thawing permafrost on the chemistry of lakes across the subarctic boreal-tundra transition, Mackenzie Delta region, Canada, Permafrost Periglac., 20, 185-199, 2009.

Kokelj, S. V., Lacelle, D., Lantz, T. C., Tunnicliffe, J., Malone, L., Clark, I. D., and Chin, K. S.: Thawing of massive ground ice in mega slumps drives increases in stream sediment and solute flux across a range of watershed scales, J. Geophys. Res.-Earth, 118, 681-692, 2013.

Kortelainen, P., Pajunen, H., Rantakari, M., and Saarnisto, M.: A large carbon pool and small sink in boreal Holocene lake sediments, Glob. Change Biol., 10, 1648-1653, 2004.

Kravtsova, V. and Bystrova, A.: Changes in thermokarst lake sizes in different regions of Russia for the last 30 years, Kriosphera Zemli, 8, 16-26, 2009 (in Russian).

Krieger, K. C.: The topographic form and evolustion of thermal erosion features: A first analysis using airborne and groundbased LiDAR in Arctic Alaska, Idaho State University, Pocatello, Idaho, USA, 2012.

Lacelle, D., Brooker, A., Fraser, R. H., and Kokelj, S. V.: Distribution and growth of thaw slumps in the Richardson MountainsPeel Plateau region, northwestern Canada, Geomorphology, 235, 40-51, 2015.

Lafrenière, M. J. and Lamoureux, S. F.: Thermal perturbation and rainfall runoff have greater impact on seasonal solute loads than physical disturbance of the active layer, Permafrost Periglac., 24, 241-251, 2013.

Lake, P.: Disturbance, patchiness, and diversity in streams, J. N. Am. Benthol. Soc., 19, 573-592, 2000.

Lamoureux, S. F. and Lafrenière, M. J.: Seasonal fluxes and age of particulate organic carbon exported from Arctic catchments impacted by localized permafrost slope disturbances, Environ. Res. Lett., 9, 045002, doi:10.1088/1748-9326/9/4/045002, 2014

Langer, M., Westermann, S., Walter Anthony, K., Wischnewski, K., and Boike, J.: Frozen ponds: production and storage of methane 
during the Arctic winter in a lowland tundra landscape in northern Siberia, Lena River delta, Biogeosciences, 12, 977-990, doi:10.5194/bg-12-977-2015, 2015.

Lantuit, H., Overduin, P. P., and Wetterich, S.: Recent progress regarding permafrost coasts, Permafrost Periglac., 24, 120-130, 2013.

Larouche, J. R., Bowden, W. B., Flinn, M. B., and Kampman, J. R.: Impacts of a thermo-erosional gully on ecosystem structure and function of an arctic alluvial tundra stream, North Slope, Alaska, J. Geophys. Res.-Biogeo., submitted, 2015.

Laudon, H., Buttle, J., Carey, S. K., McDonnell, J., McGuire, K., Seibert, J., Shanley, J., Soulsby, C., and Tetzlaff, D.: Crossregional prediction of long-term trajectory of stream water DOC response to climate change, Geophys. Res. Lett., 39, L18404, doi:10.1029/2012GL053033, 2012.

Laurion, I. and Mladenov, N.: Dissolved organic matter photolysis in Canadian arctic thaw ponds, Environ. Res. Lett., 8, 035026, doi:10.1088/1748-9326/8/3/035026, 2013.

Laurion, I., Vincent, W. F., MacInture, S., Retamal, L., Dupont, C., Francus, P., and Pienitz, R.: Variability in greenhouse gas emissions from permafrost thaw ponds, Limnol. Oceanogr., 55, 115133,2010

Le Fouest, V., Babin, M., and Tremblay, J.-É.: The fate of riverine nutrients on Arctic shelves, Biogeosciences, 10, 3661-3677, doi:10.5194/bg-10-3661-2013, 2013.

Lehner, B. and Döll, P.: Development and validation of a global database of lakes, reservoirs and wetlands, J. Hydrol., 296, 1-22, 2004.

Letscher, R. T., Hansell, D. A., Kadko, D., and Bates, N. R.: Dissolved organic nitrogen dynamics in the Arctic Ocean, Mar. Chem., 148, 1-9, 2013.

Levine, M. A. and Whalen, S. C.: Nutrient limitation of phytoplankton production in Alaskan Arctic foothill lakes, Hydrobiologia, 455, 189-201, 2001.

Lewis, T., Lafrenière, M. J., and Lamoureux, S. F.: Hydrochemical and sedimentary responses of paired High Arctic watersheds to unusual climate and permafrost disturbance, Cape Bounty, Melville Island, Canada, Hydrol. Process., 26, 2003-2018, 2012.

Liebner, S., Zeyer, J., Wagner, D., Schubert, C., Pfeiffer, E. M., and Knoblauch, C.: Methane oxidation associated with submerged brown mosses reduces methane emissions from Siberian polygonal tundra, J. Ecol., 99, 914-922, 2011.

Lohila, A., Minkkinen, K., Laine, J., Savolainen, I., Tuovinen, J.P., Korhonen, L., Laurila, T., Tietäväinen, H., and Laaksonen, A.: Forestation of boreal peatlands: Impacts of changing albedo and greenhouse gas fluxes on radiative forcing, J. Geophys. Res., 115, G04011, doi:10.1029/2010JG001327, 2010.

Lougheed, V. L., Butler, M. G., McEwen, D. C., and Hobbie, J. E.: Changes in tundra pond limnology: Re-sampling Alaskan ponds after 40 years, Ambio, 40, 589-599, 2011.

Louiseize, N. L., Lafrenière, M. J., and Hastings, M. G.: Stable isotopic evidence of enhanced export of microbially derived NO3following active layer slope disturbance in the Canadian High Arctic, Biogeochemistry, 121, 565-580, 2014.

Lundin, E. J., Giesler, R., Persson, A., Thompson, M. S., and Karlsson, J.: Integrating carbon emissions from lakes and streams in a subarctic catchment, J. Geophys. Res., 118, 1-8, 2013.

Macdonald, R. W., Harner, T., and Fyfe, J.: Recent climate change in the Arctic and its impact on contaminant pathways and inter- pretation of temporal trend data, Sci. Total Environ., 342, 5-86, 2005.

MacIntyre, S. and Melack, J. M.: Vertical and horizontal transport in lakes: Linking littoral, benthic, and pelagic habitats, J. N. Am. Benthol. Soc., 14, 599-615, 1995.

MacMillan, G. A., Girard, C., Chetelat, J., Laurion, I., and Amyot, M.: High methylmercury in Arctic and subarctic ponds is related to nutrient levels in the warming eastern Canadian Arctic, Environ. Sci. Technol., 49, 7743-7753, doi:10.1021/acs.est.5b00763, 2015.

Malone, L., Lacelle, D., Kokelj, S., and Clark, I. D.: Impacts of hillslope thaw slumps on the geochemistry of permafrost catchments (Stony Creek watershed, NWT, Canada), Chem. Geol., 356, 38 49, 2013.

Manasypov, R. M., Pokrovsky, O. S., Kirpotin, S. N., and Shirokova, L. S.: Thermokarst lake waters across the permafrost zones of western Siberia, The Cryosphere, 8, 1177-1193, doi:10.5194/tc-8-1177-2014, 2014.

Manasypov, R. M., Vorobyev, S. N., Loiko, S. V., Kritzkov, I. V., Shirokova, L. S., Shevchenko, V. P., Kirpotin, S. N., Kulizhsky, S. P., Kolesnichenko, L. G., Zemtzov, V. A., Sinkinov, V. V., and Pokrovsky, O. S.: Seasonal dynamics of organic carbon and metals in thermokarst lakes from the discontinuous permafrost zone of western Siberia, Biogeosciences, 12, 30093028, doi:10.5194/bg-12-3009-2015, 2015.

Mann, E. A., Ziegler, S., Mallory, M., and O'Driscoll, N.J.: Mercury photochemistry in snow and implications for Arctic ecosystems, Environ. Rev., 22, 331-345, 2014.

Mann, P. J., Davydova, A., Zimov, N., Spencer, R. G. M., Davydov, S., Bulygina, E., Zimov, S., and Holmes, R. M.: Controls on the composition and lability of dissolved organic matter in Siberia's Kolyma River basin, J. Geophys. Res.-Biogeo., 117, G01028, doi:10.1029/2011JG001798, 2012.

Mann, P. J., Eglinton, T. I., McIntyre, C. P., Zimov, N., Davydova, A., Vonk, J. E., Holmes, R. M., and Spencer, R. G. M.: Utilization of old permafrost carbon in headwaters of Arctic fluvial networks, Nat. Commun., 6, 7856, doi:10.1038/ncomms8856, 2015.

Martinez-Cruz, K., Sepulveda-Jauregui, A., Walter Anthony, K., and Thalasso, F.: Geographic and seasonal variation of dissolved methane and aerobic methane oxidation in Alaskan lakes, Biogeosciences, 12, 4595-4606, doi:10.5194/bg-12-4595-2015, 2015.

McCalley, C. K., Woodcroft, B. J., Hodgkins, S. B., Wehr, R. A., Kim, E.-H., Mondav, R., Crill, P. M., Chanton, J. P., Rich, V. I., Tyson, G. W., and Saleska, S. R.: Methane dynamics regulated by microbial community response to permafrost thaw, Nature, 514, 478-481, 2014.

McCarthy, K., Walker, L., and Vigoren, L.: Subsurface fate of spilled petroleum hydrocarbons in continuous permafrost, Cold Reg. Sci. Technol., 38, 43-54, 2004.

McClelland, J. W., Stieglitz, M., Pan, F., Holmes, R. M., and Peterson, B. J.: Recent changes in nitrate and dissolved organic carbon export from the upper Kuparuk River, North Slope, Alaska, J. Geophys. Res.-Biogeo., 112, G04S60, doi:10.1029/2006JG000371, 2007.

McGuire, A. D., Anderson, L. G., Christensen, T. R., Dallimore, S., Guo, L., Hayes, D. J., Heimann, M., Lorenson, T. D., Macdonald, R. W., and Roulet, N.: Sensitivity of the carbon cycle in the Arctic to climate change, Ecol. Monogr., 79, 523-555, 2009. 
McGuire, A. D., Hayes, D. J., Kicklighter, D. W., Manizza, M., Zhuang, Q., Chen, M., Follows, M. J., Gurney, K. R., McClelland, J. W., Melillo, J. M., Peterson, B. J., and Prinn, R. G.: An analysis of the carbon balance of the Arctic Basin from 1997 to 2006, Tellus B, 62, 455-474, doi:10.1111/j.16000889.2010.00497.x, 2010.

McKnight, D. M., Gooseff, M. N., Vincent, W. F., and Peterson, B. J.: High latitude rivers and streams. In: Vincent, W.F. and Laybourn-Parry, J. (Eds). Polar Lakes and Rivers - Limnology of Arctic and Antarctic Aquatic Ecosystems, Oxford University Press, UK, 83-102, 2008.

Merck, M. F., Neilson, B. T., Cory, R. M., and Kling, G. W.: Variability of in-stream and riparian storage in a beaded arctic stream, Hydrol. Process., 26, 2938-2950, doi:10.1002/hyp.8323, 2012.

Merritt, R. W., Cummins, K. W., and Berg, M. B.: An introduction to the aquatic insects of North America, 4th Edn., Kendall/Hunt Publishers, Dubuque, IA, 2008.

Mesquita, P. S., Wrona, F. J., and Prowse, T. D.: Effects of retrogressive permafrost thaw slumping on sediment chemistry and submerged macrophytes in Arctic tundra lakes, Freshwater Biol., 55, 2347-2358, 2010.

Michaelson, G. J., Ping, C. L., Kling, G. W., and Hobbie, J. E.: The character and bioactivity of dissolved organic matter at thaw and in the spring runoff waters of the arctic tundra north slope, Alaska, J. Geophys. Res., 103, 28939-28946, 1998.

Miller, W. L.: Effects of UV-radiation on aquatic humus: photochemical principles and experimental considerations, in: Aquatic Humic Substnaces - Ecology and Biogeochemistry, edited by: Hesson, D. O. and Tranvik, L. J., Springer, Berlin, Heidelberg, 126-143, 1998.

Mondav, R., Woodcroft, B. J., Kim, E.-H., McCalley, C. K., Hodgkins, S. B., Crill, P. M., Chanton, J., Hurst, G. B., VerBerkmoes, N. C., Saleska, S. R., Hugenholtz, P., Rich, V. I., and Tyson, G. W.: Discovery of a novel methanogen prevalent in thawing permafrost, Nat. Commun., 5, 3212, doi:10.1038/ncomms4212, 2014.

Moquin, P. A., Mesquita, P. S., Wrona, F. J., and Prowse, T. D.: Responses of benthic invertebrate communities to shoreline retrogressive thaw slumps in arctic upland lakes, Freshwater Science, 33, 1108-1118, 2014.

Mortimer, C. H. and Mackereth, F. J. H.: Convection and its consequences in ice-covered lakes, Verh. Internat. Ver. Limnol., 13, 923-932, 1958.

Muster, S., Heim, B., Abnizova, A., and Boike, J.: Water body distributions across scales: A remote sensing based comparison of three arctic tundra wetlands, Remote Sensing, 5, 1498-1523, 2013.

Myhre, G., Shindell, D., Breon, F. M., Collins, W., Fuglestvedt, J., Huang, J., Koch, D., Lamarque, J. F., Lee, D., Mendoza, B., Nakajima, T., Robock, A., Stephens, G., Takemura, T., and Zhang, H.: Anthropogenic and Natural Radiative Forcing, in: Climate Change 2013: The Physical Science Basis. Contribution of Working Group I to the Fifth Assessment Report of the Intergovernmental Panel on Climate Change, Cambridge University Press, Cambridge, United Kingdom and New York, NY, USA, 659-740, 2013

Neff, J. C., Finlay, J. C., Zimov, S. A., Davydov, S. P., Carrasco, J. J., Schuur, E. A. G., and Davydova, A. I.: Seasonal changes in the age and structure of dissolved organic carbon in
Siberian rivers and streams, Geophys. Res. Lett., 33, L23401, doi:10.1029/2006GL028222, 2006.

Negandhi, K., Laurion, I., Whiticar, M. J., Galand, P. E., Xu, X., and Lovejoy, C.: Small thaw ponds: An unaccounted source of methane in the Canadian High Arctic, PLoS ONE, 8, e78204, doi:10.1371/journal.pone.0078204, 2013.

Negandhi, K., Laurion, I., and Lovejoy, C.: Bacterial communities and greenhouse gas emissions of shallow ponds in the High Arctic, Polar Biol., 37, 1669-1683, 2014.

Notaro, M. and Liu, Z: Potential Impact of the Eurasian Boreal Forest on North Pacific Climate Variability, American Meteorological Society, 20, 981-992, 2007.

O’Brien, W. J., Barfield, M., Bettez, N., Hershey, A. E., Hobbie, J. E., Kipphut, G., Kling, G., and Miller, M. C.: Long-term response and recovery to nutrient addition of a partitioned arctic lake, Freshwater Biol., 50, 731-741, 2005.

O’Donnell, J. A., Aiken, G. R., Walvoord, M. A., Raymond, P. A., Dornblaser, M. M., and Heckman, K.: Using dissolved organic matter age and composition to detect permafrost thaw in boreal watersheds of interior Alaska, J. Geophys. Res.-Biogeo., 119, 2155-2170, doi:10.1002/2014JG002695, 2014.

Olefeldt, D. and Roulet, N. T.: Effects of permafrost and hydrology on the composition and transport of dissolved organic carbon in a subarctic peatland complex, J. Geophys. Res.-Biogeo., 117, 1$15,2012$.

Olefeldt, D. and Roulet, N. T.: Permafrost conditions in peatlands regulate magnitude, timing, and chemical composition of catchment dissolved organic carbon export, Global. Change. Biol., 20, 3122-3136, 2014

Olefeldt, D., Turetsky, M. R., and Blodau, C.: Altered composition and microbial versus UV-mediated degradation of dissolved organic matter in boreal soils following wildfire, Ecosystems, 16, 1396-1412, 2013.

Ovenden, L.: Vegetation colonizing the bed of a recently drained thermokarst lake (Illisarvik), Northwest Territories, Can. J. Bot., 64, 2688-2692, 1986.

Parham, L. M., Prokushkin, A. S., Pokrovsky, O. S., Titov, S. V., Grekova, E., Shirokova, L. S., and McDowell, W. H.: Permafrost and fire as regulators of stream chemistry in basins of the Central Siberian Plateau, Biogeochemistry, 116, 55-68, doi:10.1007/s10533-013-9922-5, 2013.

Parker, S. M. and Huryn, A. D.: Food web structure and function in two Arctic streams with contrasting disturbance regimes, Freshwater Biol., 51, 1249-1263, 2006.

Paytan, A., Lecher, A. L., Dimova, N., Sparrow, K. J., Garcia Tigreros, F., Murray, J., Tulaczyk, S., and Kessler, J. D.: Methane transport from the active layer to lakes in the Arctic using Toolik Lake, Alaska, as a case study, P. Natl. Acad. Sci. USA, 112, 3636-3640, 2015.

Pearce, A. R., Rastetter, E. B., Kwiatkowski, B. L., Bowden, W. B., Mack, M. C., and Jiang, Y.: Recovery of arctic tundra from thermal erosion disturbance is constrained by nutrient accumulation: a modeling analysis, Ecol. Appl., 25, 1271-1289, doi:10.1890/14-1323.1, 2014.

Pelletier, J. D.: Formation of oriented thaw lakes by thaw slumping, J. Geophys. Res., 110, F02018, doi:10.1029/2004JF000158, 2005.

Pelletier, L., Strachan, I. B., Garneau, M., and Roulet, N. T.: Carbon release from boreal peatland open water pools: Implication 
for the contemporary $\mathrm{C}$ exchange: Carbon release from peatland pools, J. Geophys. Res.-Biogeo., 119, 207-222, 2014.

Peterson, B. J., Hobbie, J. E., Hershey, A. E., Lock, M. A., Ford, T. E., Vestal, J. R., McKinley, V. L., Hullar, M. A., Miller, M. C., Ventullo, R. M., and Volk, G. S.: Transformation of a tundra river from heterotrophy to autotrophy by addition of phosphorus, Science, 229, 1383-1386, 1985.

Petrone, K. C., Hinzman, L. D., Shibata, H., Jones, J. B., and Boone, R. D.: The influence of fire and permafrost on sub-arctic stream chemistry during storms, Hydrol. Process., 21, 423-434, 2007.

Peura, S., Bertilsson, S., Jones, R. I., and Eiler, A.: Resistant microbial cooccurrence patterns inferred by network topology, Appl. Environ. Microbiol., 81, 2090-2097, 2015.

Ping, C. L., Michaelson, G. J., Jorgenson, M. T., Kimble, J. M., Epstein, H., Romanovsky, V. E., and Walker, D. A.: High stocks of soil organic carbon in the North American Arctic region, Nat. Geosci., 1, 615-619, 2008.

Podgrajsek, E., Sahlée, E., Bastviken, D., Holst, J., Lindroth, A., Tranvik, L., and Rutgersson, A.: Comparison of floating chamber and eddy covariance measurements of lake greenhouse gas fluxes, Biogeosciences, 11, 4225-4233, doi:10.5194/bg-114225-2014, 2014a.

Podgrajsek, E., Sahlée, E., and Rutgersson, A.: Diurnal cycle of lake methane flux, J. Geophys. Res.-Biogeo., 119, 236-248, 2014 b.

Pokrovsky, O. S., Shirokova, L. S., Kirpotin, S. N., Audry, S., Viers, J., and Dupré, B.: Effect of permafrost thawing on organic carbon and trace element colloidal speciation in the thermokarst lakes of western Siberia, Biogeosciences, 8, 565-583, doi:10.5194/bg-8565-2011, 2011.

Pokrovsky, O. S., Shirokova, L. S., Kirpotin, S. N., Kulizhsky, S. P., and Vorobiev, S. N.: Impact of western Siberia heat wave 2012 on greenhouse gases and trace metal concentration in thaw lakes of discontinuous permafrost zone, Biogeosciences, 10, 5349-5365, doi:10.5194/bg-10-5349-2013, 2013.

Pokrovsky, O. S., Manasypov, R. M., Loiko, S., Shirokova, L. S., Krickov, I. A., Pokrovsky, B. G., Kolesnichenko, L. G., Kopysov, S. G., Zemtzov, V. A., Kulizhsky, S. P., Vorobyev, S. N., and Kirpotin, S. N.: Permafrost coverage, watershed area and season control of dissolved carbon and major elements in western Siberian rivers, Biogeosciences, 12, 6301-6320, doi:10.5194/bg12-6301-2015, 2015.

Polishuk, Y.: Thermokarst lake dynamics, Modeling and prediction, LAP LAMBERT Academic Publishing GmbH \& Co, Saarbrucken, 126 pp., 2012 (in Russian).

Polishuk, Y. and Sharonov, D.: Study of the Thermokarst Lakes Dynamics in the Mountain Valleys of Altai, Issledovaniye Zemli iz Kosmosa, 1, 44-47, 2013 (in Russian).

Prokushkin, A. S., Pokrovsky, O. S., Shirokova, L. S., Korets, M. A., Viers, J., Prokushkin, S. G., Amon, R. M. W., Guggenberger, G., and McDowell, W. H.: Sources and the flux pattern of dissolved carbon in rivers of the Yenisey basin draining the Central Siberian Plateau, Environ. Res. Lett., 6, 045212, doi:10.1088/1748-9326/6/4/045212, 2011.

Prowse, T. D., Wrona, F. J., Reist, J. D., Gibson, J. J., Hobbie, J. E., Lévesque, L. M. J., and Vincent, W. F.: Climate change effects on hydroecology of Arctic freshwater ecosystems, Ambio, 35, 347-358, 2006.

Przytulska, A., Comte, J., Crevecoeur, S., Lovejoy, C., Laurion, I., and Vincent, W. F.: Phototrophic pigment diversity and picophy- toplankton abundance in permafrost thaw lakes, Biogeosciences Discuss., 12, 12121-12156, doi:10.5194/bgd-12-12121-2015, 2015.

Rachold, V., Eicken, H., Gordeev, V. V., Grigoriev, M. N., Hubberten, H. W., Lisitzin, A. P., Shevchenko, V. P., and Schirrmeister, L.: Modern terrigenous organic carbon input to the Arctic Ocean, in: The Organic Carbon Cycle in the Arctic Ocean, edited by: Stein, R. and MacDonald, R., Springer, Berlin, Heidelberg, 33-55, 2004.

Rastetter, E. B., Kwiatkowski, B. L., Le Dizes, S., and Hobbie, J. E.: The role of down-slope water and nutrient fluxes in the response of arctic hill slopes to climate change, Biogeochemistry, 69, 3762, 2004.

Rautio, M., Dufresne, F., Laurion, I., Bonilla, S., Vincent, W. F., and Christoffersen, K. S.: Shallow freshwater ecosystems of the circumpolar Arctic, Ecoscience, 18, 204-222, 2011.

Raymond, P. A., McClelland, J. W., Holmes, R. M., Zhulidov, A. V., Mull, K., Peterson, B. J., Striegl, R. G., Aiken, G. R., and Gurtovaya, T. Y.: Flux and age of dissolved organic carbon exported to the Arctic Ocean: A carbon isotopic study of the five largest arctic rivers, Global Biogeochem. Cy., 21, GB4011, doi:10.1029/2007GB002934, 2007.

Reeburgh, W. S., King, J. Y., Regli, S. K., Kling, G. W., Auerbach, N. A., and Walker, D. A.: A $\mathrm{CH}_{4}$ emission estimate for the $\mathrm{Ku}-$ paruk River basin, Alaska, J. Geophys. Res., 103, 29005-29013, 1998.

Repo, M. E., Huttunen, J. T., Naumov, A. V., Chichulin, A. V., Lapshina, E. D., Bleuten, W., and Martikainen, P. J.,: Release of $\mathrm{CO}_{2}$ and $\mathrm{CH}_{4}$ from small wetland lakes in western Siberia, Tellus B, 59, 788-796, doi:10.1111/j.1600-0889.2007.00301.x, 2007.

Retamal, L., Bonilla, S., and Vincent, W. F.: Optical gradients and phytoplankton production in the Mackenzie River and coastal Beaufort Sea, Polar Biol., 31, 363-379, 2008.

Rethemeyer, J., Schubotz, F., Talbot, H. M., Cooke, M. P., Hinrichs, K.-U., and Mollenhauer, G.: Distribution of polar membrane lipids in permafrost soils and sediments of a small high Arctic catchment, Org. Geochem., 41, 1130-1145, 2010.

Richardson, D. C., Newbold, J. D., Aufdenkampe, A. K., Taylor, P. G., and Kaplan, L. A.: Measuring heterotrophic respiration rates of suspended particulate organic carbon from stream ecosystems, Limnol. Oceanogr.-Meth., 11, 247-261, 2013.

Roehm, C. L., Giesler, R., and Karlsson, J.: Bioavailability of terrestrial organic carbon to lake bacteria: The case of a degrading subarctic permafrost mire complex, J. Geophys. Res.-Biogeo., 114, G03006, doi:10.1029/2008JG000863, 2009.

Roiha, T., Laurion, I., and Rautio, M.: Carbon dynamics in highly heterotrophic subarctic thaw ponds, Biogeosciences Discuss., 12, 11707-11749, doi:10.5194/bgd-12-11707-2015, 2015.

Romanovsky, V. E., Smith, S. L., and Christiansen, H. H.: Permafrost thermal state in the polar Northern Hemisphere during the International Polar Year 2007-2009: a synthesis, Permafrost Periglac., 21, 106-116, 2010.

Rossi, P., Laurion, I., and Lovejoy, C.: Distribution and identity of bacteria in subarctic permafrost thaw ponds, Aquat. Microb. Ecol., 69, 231-245, 2013.

Rouse, W. R., Oswald, C. J., Binyamin, J., Spence, C., Schertzer, W. M., Blanken, P. D., Bussières, N., and Duguay, C. R.: The role of northern lakes in a regional energy balance, J. Hydrometeorol., 6, 291-305, 2005. 
Rydberg, J., Klaminder, J., Rosén, P., and Bindler, R.: Climate driven release of carbon and mercury from permafrost mires increases mercury loading to sub-arctic lakes, Sci. Total Environ., 408, 4778-4783, 2010.

Sachs, T., Giebels, M., Boike, J., and Kutzbach, L.: Environmental controls on $\mathrm{CH} 4$ emission from polygonal tundra on the microsite scale in the Lena river delta, Siberia: controls on tundra $\mathrm{CH}_{4}$ flux and scaling, Glob. Change Biol., 16, 3096-3110, 2010.

Sannikov, G.: Mapping-based research into the thermokarst lakes within the Bova gas field territory, Yamal peninsula, Kriosphera Zemli, 2, 30-37, 2012 (in Russian).

Schädel, C., Schuur, E. A. G., Bracho, R., Elberling, B., Knoblauch, C., Lee, H., Luo, Y., Shaver, G. R., and Turetsky, M. R.: Circumpolar assessment of permafrost $\mathrm{C}$ quality and its vulnerability over time using long-term incubation data, Glob. Change Biol., 20, 641-652, 2014.

Schaefer, K., Lantuit, H.,Romanovsky, V. E., Schuur, E. A. G., and Witt, R.: The impact of the permafrost carbon feedback on global climate, Environ. Res. Lett., 9, 085003, doi:10.1088/17489326/9/8/085003, 2014.

Schreiner, K., Bianchi, T. S., and Rosenheim, B. E.: Evidence for permafrost thaw and transport from an Alaskan North Slope watershed, Geophys. Res. Lett., 41, 3117-3126, 2014.

Schuur, E. A. G., Bockheim, J., Canadell, J. G., Euskirchen, E., Field, C. B., Goryachkin, S. V., Hagemann, S., Kuhry, P., Lafleur, P. M., Lee, H., Mazhitova, G., Nelson, F. E., Rinke, A., Romanovksy, V.E., Shiklomanov, N., Tarnocai, C., Venevsky, S., Vogel, J. G., and Zimov, S. A.: Vulnerability of permafrost carbon to climate change: Implications for the global carbon cycle, BioScience, 58, 701-714, 2008.

Schuur, E. A. G., Vogel, J. G., Crummer, K.G., Lee, H., Sickman, J. O., and Osterkamp, T. E.: The effect of permafrost thaw on old carbon release and net carbon exchange from tundra, Nature, 459, 556-559, 2009.

Schuur, E. A. G., McGuire, A. D., Schädel, C., Grosse, G., Harden, J. W., Hayes, D. J., Hugelius, G., Koven, C. D., Kuhry, P., Lawrence, D. M., Natali, S. M., Olefeldt, D., Romanovsky, V. E., Schaefer, K., Turetsky, M. R., Treat, C. C., and Vonk, J. E.: Climate change and the permafrost carbon feedback, Nature, 250, 171-178, 2015.

Seekell, D. A., Lapierre, J. F., Ask, J., Bergström, A. K., Deininger, A., Rodríguez, P., and Karlsson, J.: The influence of dissolved organic carbon on primary production in northern lakes, Limnol. Oceanogr., 60, 1276-1285, doi:10.1002/lno.10096, 2015.

Sepulveda-Jauregui, A., Walter Anthony, K. M., Martinez-Cruz, K., Greene, S., and Thalasso, F.: Methane and carbon dioxide emissions from 40 lakes along a north-south latitudinal transect in Alaska, Biogeosciences, 12, 3197-3223, doi:10.5194/bg-123197-2015, 2015.

Sharonov, D. S., Bryksina, N. A., Polishuk, V. Y., and Polishuk, Y. M.: Comparative analysis of West Siberian and Mountain Altay permafrost based on satellite imagery, Current problems in remote sensing of the earth from space, 9, 313-319, 2012 (in Russian).

Shiklomanov, N. I., Streletskiy, D. A., Little, J. D., and Nelson, F. E.: Isotropic thaw subsidence in undisturbed permafrost landscapes, Geophys. Res. Lett., 40, 6356-6361, 2013.

Shirokova, L. S., Pokrovsky, O. S., Kirpotin, S. N., Desmukh, C., Pokrovsky, B. G., Audry, S., and Viers, J.: Biogeochemistry of organic carbon, $\mathrm{CO}_{2}, \mathrm{CH}_{4}$, and trace elements in thermokarst water bodies in discontinuous permafrost zones of Western Siberia, Biogeochemistry, 113, 573-593, doi:10.1007/s10533012-9790-4, 2013.

Smith, L. C., Sheng, Y., McDonald, G. M., and Hinzman, L. D.: Disappearing arctic lakes, Science, 308, 1429 , doi:10.1126/science.1108142, 2005.

Smith, L. C., Sheng, Y., and MacDonald, G. M.: A first pan-Arctic assessment of the influence of glaciation, permafrost, topography and peatlands on northern hemisphere lake distribution, Permafrost Periglac., 18, 201-208, 2007.

Sobek, S., Algesten, G., Bergström, A.-K., Jansson, M., and Tranvik, L. J.: The catchment and climate regulation of $p \mathrm{CO}_{2}$ in boreal lakes, Glob. Change Biol., 9, 630-641, 2003.

Sobek, S., Tranvik, L. J., and Cole, J. J.: Temperature independence of carbon dioxide supersaturation in global lakes, Global Biogeochem. Cy., 19, GB2003, doi:10.1029/2004GB002264, 2005.

Sobek, S., Anderson, N. J., Bernasconi, S. M., and Del Sontro, T.: Low organic carbon burial efficiency in arctic lake sediments, J. Geophys. Res.-Biogeo., 119, 1231-1243, 2014.

Sondergaard, M., Jensen, J. P., and Jeppesen, E.: Role of sediment and internal loading of phosphorus in shallow lakes, Hydrobiologia, 506, 135-145, 2003.

Spence, C., Kokelj, S. V., and Ehsanzadeh, E.: Precipitation trends contribute to streamflow regime shifts in northern Canada, in: Cold Regions Hydrology in a Changing Climate, edited by: Yang, D., Marsh, P., and Gelfan, A., IAHS Publication, Int Assoc Hydrological Sciences, Wallingford, 3-8, 2011.

Spencer, R. G. M., Aiken, G. R., Wickland, K. P., Striegl, R. G., and Hernes, P. J.: Seasonal and spatial variability in dissolved organic matter quantity and composition from the Yukon River basin, Alaska, Global Biogeochem. Cy., 22, GB4002, doi:10.1029/2008GB003231, 2008.

Spencer, R. G. M., Mann, P. J., Dittmar, T., Eglinton, T. I., McIntyre, C., Holmes, R. M., Zimov, N., and Stubbins, A.: Detecting the signature of permafrost thaw in Arctic rivers, Geophys. Res. Lett., 42, 2830-2835, doi:10.1002/2015GL063498, 2015.

Squires, M. M. and Lesack, L. F. W.: The relation between sediment nutrient content and macrophyte biomass and community structure along a water transparency gradient among lakes of the Mackenzie Delta, Can. J. Fish. Aquat. Sci, 60, 333-343, 2003.

Stein, R. and Fahl, K.: Holocene accumulation of organic carbon at the Laptev Sea continental margin (Arctic Ocean): sources, pathways, and sinks, Geo-Mar. Lett., 20, 27-36, 2000.

Steinacher, M., Joos, F., Frölicher, T. L., Plattner, G.-K., and Doney, S. C.: Imminent ocean acidification in the Arctic projected with the NCAR global coupled carbon cycle-climate model, Biogeosciences, 6, 515-533, doi:10.5194/bg-6-515-2009, 2009.

Stern, G. A., Macdonald, R. W., Outridge, P. M., Wilson, S., Chételat, J., Cole, A., Hintelmann, H., Loseto, L. L., Steffen, A., Wang, F., and Zdanowicz, C.: How does climate change influence Arctic mercury?, Sci. Total Environ., 414, 22-42, 2012.

Steven, B., Kuske, C. R., Lionard, M., and Vincent, W. F.: High bacterial diversity of biological soil crusts in water tracks over permafrost in the high Arctic polar desert, PLoS ONE, 8, e71489, doi:10.1371/journal.pone.0071489, 2013.

Stieglitz, M., Shaman, J., McNamara, J., Kling, G. W., Engel, V., and Shanley, J: An approach to understanding hydrologic connectivity on the hillslope and the implications 
for nutrient transport, Global Biogeochem. Cy., 17, 1105, doi:10.1029/2003GB002041, 2003.

Strauss, J., Schirrmeister, L., Grosse, G., Wetterich, S., Ulrich, M., Herzschuh, U., and Hubberten, H.-W.: The deep permafrost carbon pool of the Yedoma region in Siberia and Alaska, Geophys. Res. Lett., 40, 6165-6170, doi:10.1002/2013GL058088, 2013.

Striegl, R. G., Aiken, G. R., Dornblaser, M. M., Raymond, P. A., and Wickland, K. P.: A decrease in discharge-normalized DOC export by the Yukon River during summer through autumn, Geophys. Res. Lett., 32, L21413, doi:10.1029/2005GL024413, 2005.

Striegl, R. G., Dornblaser, M. M., McDonald, C. P., Rover, J. R., and Stets, E. G.: Carbon dioxide and methane emissions from the Yukon River system, Global Biogeochem. Cy., 26, GB0E05, doi:10.1029/2012GB004306, 2012.

Suttle, C. A.: Marine viruses - major players in the global ecosystem, Nat. Rev. Microbiol., 5, 801-812, 2007.

Tank, S. E., Lesack, L. F. W., and Hesslein, R. H.: Northern delta lakes as summertime $\mathrm{CO}_{2}$ absorbers within the Arctic landscape, Ecosystems, 12, 144-157, 2009.

Tank, S. E., Frey, K. E., Striegl, R. G., Raymond, P. A., Holmes, R. M., McClelland, J. W., and Peterson, B. J.: Landscapelevel controls on dissolved carbon flux from diverse catchments of the circumboreal, Global Biogeochem. Cy., 26, GB0E02, doi:10.1029/2012GB004299, 2012a.

Tank, S. E., Manizza, M., Holmes, R. M., McClelland, J. W., and Peterson, B. J.: The processing and impact of dissolved riverine nitrogen in the Arctic Ocean, Estuar. Coast., 35, 401-415, $2012 \mathrm{~b}$.

Tank, S. E., Raymond, P. A., Striegl, R. G., McClelland, J. W., Holmes, R. M., Fiske, G. J., and Peterson, B. J.: A land-to-ocean perspective on the magnitude, source and implication of DIC flux from major Arctic rivers to the Arctic Ocean, Global Biogeochem. Cy., 26, GB4018, doi:10.1029/2011GB004192, 2012c.

Tarnocai, C., Canadell, J. G., Schuur, E. A. G., Kuhry, P., Mazhitova, G., and Zimov, S.: Soil organic carbon pools in the northern circumpolar permafrost region, Global Biogeochem. Cy., 23, GB2023, doi:10.1029/2008GB003327, 2009.

Teodoru, C. R., del Giorgio, P. A., Prairie, Y. T., and Camire, C.: Patterns in $\mathrm{pCO}_{2}$ in boreal streams and rivers of northern Quebec, Canada, Global Biogeochem. Cy., 23, GB2012, doi:10.1029/2008GB003404, 2009.

Thienpont, J. R., Rühland, K. M., Pisaric, M. F. J., Kokelj, S. V., Kimpe, L. E., Blais, J. M., and Smol, J. P.: Biological responses to permafrost thaw slumping in Canadian Arctic lakes, Freshwater Biol., 58, 337-353, 2013.

Thompson, M. S., Kokelj, S. V., Prowse, T. D., and Wrona, F. J.: The impact of sediments derived from thawing permafrost on tundra lake water chemistry: an experimental approach, in: Proceedings of the 9th International Conference on Permafrost, edited by: Kane, D. L. and Hinkel, K. M., Volume 2, Institute of Northern Engineering, University of Alaska, Fairbanks, Alaska, 17631768, 2008.

Thompson, M. S., Wrona, F. J., and Prowse, T. D.: Shifts in plankton, nutrient and light relationships in small tundra lakes caused by localized permafrost thaw, Arctic, 65, 367-376, 2012.

Tranvik, L. J., Downing, J. A., Cotner, J. B., Loiselle, S. A., Striegl, R. G., Ballatore, T. J., Dillon, P., Finlay, K., Fortino, K., Knoll, L. B., Kortelainen, P. L., Kutser, T., Larsen, S., Laurion, I., Leech, D. M., McCallister, S. L., McKnight, D. M., Melack, J. M., Overholt, E., Porter, J. A., Prairie, Y., Renwick, W. H., Roland, F.,
Sherman, B. S., Schindler, D.W., Sobek, S., Tremblay, A., Vanni, M. J., Verschoor, A. M., von Wachenfeldt, E., and Weyhenmeyer, G. A.: Lakes and reservoirs as regulators of carbon cycling and climate, Limnol. Oceanogr., 54, 2298-2314, 2009.

Trotsenko, Y. A. and Murrell, J. C.: Metabolic aspects of aerobic obligate methanotrophy, Adv. Appl. Microbiol., 63, 183-229, 2008.

Tseng, C. M., Lamborg, C., Fitzgerald, W. F., and Engstrom, D. R.: Cycling of dissolved elemental mercury in Arctic Alaskan lakes, Geochim. Cosmochim. Ac., 68, 1173-1184, 2004.

Turner, K. W., Edwards, T. W. D., and Wolfe, B. B.: Characterising runoff generation processes in a lake-rich thermokarst landscape (Old Crow Flats, Yukon, Canada) using d18O, d2H and d-excess measurements, Permafrost Periglac., 25, 53-59, 2014.

Uehlinger, U. and Naegeli, M. W.: Ecosystem metabolism, disturbance, and stability in a prealpine gravel bed river, J. N. Am. Benthol. Soc., 17, 165-178, 1998.

van Huissteden, J., Berrittella, C., Parmentier, F. J. W., Mi, Y., Maximov, T. C., and Dolman, A. J.: Methane emissions from permafrost thaw lakes limited by lake drainage, Nature Climate Change, 1, 119-123, 2011.

Vasiliev, A., Kanevskiy, M., Cherkashov, G., and Vanshtein, B.: Coastal dynamics at the Barents and Kara Sea key sites, GeoMar. Lett., 25, 110-120, 2005.

Vavrus, S., Holland, M. M., and Bailey, D. A.: Changes in Arctic clouds during intervals of rapid sea ice loss, Clim. Dynam., 36 , 1475-1489, 2010.

Vesala, T., Huotari, J., Rannik, Ü., Suni, T., Smolander, S., Sogachev, A., Launiainen, S., and Ojala, A.: Eddy covariance measurements of carbon exchange and latent and sensible heat fluxes over a boreal lake for a full open-water period, J. Geophys. Res., 111, D11101, doi:10.1029/2005JD006365, 2006.

Vesala, T., Kljun, N., Rannik, U., Rinne, J., Sogachev, A., Markkanen, T., Sabelfeld, K., Foken, T., and Leclerc, M. Y.: Flux and concentration footprint modelling: State of the art, Environ. Pollut., 152, 653-666, 2008.

Vesala, T., Eugster, W., and Ojala, A.: Eddy covariance measurements over lakes, in Eddy Covariance - A practical guide to measurement and data analysis, edited by: Aubinet, M., Vesala, T., and Papale, D., 365-376, Springer Atmospheric Sciences, Dordrecht, 2012.

Vincent, W. F. and Belzile, C.: Biological UV exposure in the polar oceans: Arctic-Antarctic comparisons, in: Antarctic Biology in a Global Context, edited by: Huiskes, A. H. L., Gieskes, W. W. C., Rozema, J., Schorno, R. M. L., van der Vies, S. M., and Wolff, W. J., Backhuys Publishers, Leiden, the Netherlands, 176-181, 2003.

Vonk, J. E. and Gustafsson, Ö.: Permafrost-carbon complexities, Nat. Geosci., 6, 675-676, 2013.

Vonk, J. E., van Dongen, B. E., and Gustafsson, Ö.: Selective preservation of old organic carbon fluvially released from sub-arctic soils, Geophys. Res. Lett., 37, L11605, doi:10.1029/2010GL042909, 2010.

Vonk, J. E., Alling, V., Rahm, L., Morth, C. M., Humborg, C., and Gustafsson, O.: A centennial record of fluvial organic matter input from the discontinuous permafrost catchment of Lake Tornetrask, J. Geophys. Res.-Biogeo., 117, G03018, doi:10.1029/2011JG001887, 2012a.

Vonk, J. E., Sanchez-Garcia, L., van Dongen, B. E., Alling, V., Kosmach, D., Charkin, A., Semiletov, I. P., Dudarev, O. V., 
Shakhova, N., Roos, P., Eglinton, T. I., Andersson, A., and Gustafsson, O.: Activation of old carbon by erosion of coastal and subsea permafrost in Arctic Siberia, Nature, 489, 137-140, $2012 b$.

Vonk, J. E., Mann, P. J., Davydov, S., Davydova, A., Spencer, R. G. M., Schade, J., Sobczak, W. V., Zimov, N., Zimov, S., Bulygina, E., Eglinton, T. I., and Holmes, R. M.: High biolability of ancient permafrost carbon upon thaw, Geophys. Res. Lett., 40, 2689 2693, 2013.

Vonk, J. E., Semiletov, I. P., Dudarev, O. V., Eglinton, T. I., Andersson, A., Shakhova, N., Charkin, A., Heim, B., and Gustafsson, Ö.: Preferential burial of permafrost-derived organic carbon in Siberian-Arctic shelf waters, J. Geophys. Res.-Oceans, 119, 8410-8421, doi:10.1002/2014JC010261, 2014.

Vonk, J. E., Tank, S. E., Mann, P. J., Spencer, R. G. M., Treat, C. C., Striegl, R. G., Abbott, B. W., and Wickland, K. P.: Biodegradability of dissolved organic carbon in permafrost soils and aquatic systems: a meta-analysis, Biogeosciences, 12, 69156930, doi:10.5194/bg-12-6915-2015, 2015.

Waldrop, M. P., Wickland, K. P., White III, R., Berhe, A. A., Harden, J. W., and Romanovsky, V. E.: Molecular investigations into a globally important carbon pool: permafrost-protected carbon in Alaskan soils, Glob. Change Biol., 16, 2543-2554, 2010.

Walter, K. M., Zimov, S. A., Chanton, J. P., Verbyla, D., and Chapin, F. S.: Methane bubbling from Siberian thaw lakes as a positive feedback to climate warming, Nature, 443, 71-75, 2006.

Walter, K. M., Edwards, M. E., Grosse, G., Zimov, S. A., and Chapin, F. S.: Thermokarst lakes as a source of atmospheric $\mathrm{CH}_{4}$ during the last deglaciation, Science, 318, 633-636, 2007.

Walter, K. M., Engram, M., Duguay, C. R., Jeffries, M. O., and Chapin, F. S.: The potential use of synthetic aperture radar for estimating methane ebullition from Arctic lake, J. Am. Water Resour. As., 44, 305-315, 2008.

Walter Anthony, K. M., Anthony, P., Grosse, G., and Chanton, J.: Geologic methane seeps along boundaries of Arctic permafrost thaw and melting glaciers, Nat. Geosci., 5, 419-426, 2012.

Walter Anthony, K. M. and Anthony, P.: Constraining spatial variability of methane ebullition seeps in thermokarst lakes using point process models, J. Geophys. Res.-Biogeo., 118, 10151034, 2013.

Walter Anthony, K. M., Zimov, S. A., Grosse, G., Jones, M. C., Anthony, P. M., Chapin III, F. S., Finlay, J. C., Mack, M. C., Davydov, S., Frenzel, P. and Frolking, S.: A shift of thermokarst lakes from carbon sources to sinks during the Holocene epoch, Nature, 511, 452-456, 2014.

Walvoord, M. A. and Striegl, R. G.: Increased groundwater to stream discharge from permafrost thawing in the Yukon River basin: Potential impacts on lateral export of carbon and nitrogen, Geophys. Res. Lett., 34, L12402, doi:10.1029/2007GL030216, 2007.

Walvoord, M. A., Voss, C. I., and Wellman, T. P.: Influence of permafrost distribution on groundwater flow in the context of climate-driven permafrost thaw: Example from Yukon Flats Basin, Alaska, United States, Water Resour. Res., 48, W07524, doi:10.1029/2011WR011595, 2012.

Ward, C. P. and Cory, R. M.: Chemical composition of dissolved organic matter draining permafrost soils, Geochim. Cosmochim. Ac., 167, 63-79, doi:10.1016/j.gca.2015.07.001, 2015.
Watanabe, S., Laurion, I., Chokmani, K., Pienitz, R., and Vincent, W. F.: Optical diversity of thaw ponds in discontinuous permafrost: A model system for water color analysis, J. Geophys. Res., 116, G02003, doi:10.1029/2010JG001380, 2011.

West, J. J. and Plug, L. J.: Time-dependent morphology of thaw lakes and taliks in deep and shallow ground ice, J. Geophys. Res.Earth, 113, F01009, doi:10.1029/2006JF000696, 2008.

Wickland, K. P., Striegl, R. G., Neff, J. C., and Sachs, T.: Effects of permafrost melting on $\mathrm{CO}_{2}$ and $\mathrm{CH}_{4}$ exchange of a poorlydrained black spruce lowland, J. Geophys. Res.-Biogeo., 111, G02011, doi:10.1029/2005JG000099, 2006.

Wickland, K. P., Neff, J. C., and Aiken, G. R.: Dissolved organic carbon in Alaskan boreal forest: Sources, chemical characteristics, and biodegradability, Ecosystems, 10, 1323-1340, 2007.

Wickland, K. P., Aiken, G. R., Butler, K., Dornblaser, M. M., Spencer, R. G. M., and Striegl, R. G.: Biodegradability of dissolved organic carbon in the Yukon River and its tributaries: Seasonality and importance of inorganic nitrogen, Global Biogeochem. Cy., 26, GB0E03, doi:10.1029/2012GB004342, 2012.

Wik, M., Crill, P. M., Bastviken, D., Danielsson, A., and Norbäck, E.: Bubbles trapped in arctic lake ice: Potential implications for methane emissions, J. Geophys. Res., 116, G03044, doi:10.1029/2011JG001761, 2011.

Wik, M., Varner, R., Walter Anthony, K. M., MacIntyre, S., and Bastviken, D.: Methane emission potential of pan-Arctic lakes and ponds based on forty years of research, Nat. Geosci., in review, 2015.

Wille, C., Kutzbach, L., Sachs, T., Wagner, D., and Pfeiffer, E.-M.: Methane emission from Siberian arctic polygonal tundra: eddy covariance measurements and modeling, Glob. Change Biol., 14, 1395-1408, 2008

Yamamoto-Kawai, M., McLaughlin, F. A., Carmack, E. C., Nishino, S., and Shimada, K.: Aragonite undersaturation in the Arctic Ocean: Effects of ocean acidification and sea ice melt, Science, 326, 1098-1100, 2009.

Zarnetske, J. P., Gooseff, M. N., Bowden, W. B., Greenwald, M. J., Brosten, T., Bradford, J. H., and McNamara, J. P.: Influence of morphology and permafrost dynamics on hyporheic exchange in Arctic headwater streams under warming climate conditions, Geophys. Res. Lett., 35, L02501, doi:10.1029/2007GL032049, 2008.

Zimov, S. A., Voropaev, Y. V., Semiletov, I. P., Davidov, S. P., Prosiannikov, S. F., Chapin, F. S., Chapin, M. C., Trumbore, S., and Tyler, S.: North Siberian lakes: A methane source fueled by Pleistocene carbon, Science, 277, 800-802, 1997.

Zimov, S. A., Voropaev, Y. V., Davydov, S. P., Zimova, G. M., Davydova, A. I., Chapin III, F. S., and Chapin, M. C.: Flux of methane from north Siberian aquatic systems: Influence on atmospheric methane, in: Permafrost Response on Economic Development, Environmental Security and Natural Resources, NATO Science Series 2, 76, edited by: Paepe, R. and Melnikov, V. P., Kluwer Academic Publishers, Dordrecht, Netherlands, Boston, Massachusetts, USA, 511-524, 2001.

Zimov, S. A., Schuur, E. A. G., and Chapin, F. S.: Permafrost and the Global Carbon Budget, Science, 312, 1612-1613, 2006. 